Claudia Quadros Fagali

\title{
Síndrome de Sotos: pesquisa de microdeleções e mutações intragênicas no gene NSD1
}

Dissertação apresentada ao Instituto de Biociências da Universidade de São Paulo, para obtenção do título de Mestre em Biologia/Genética

São Paulo 
Claudia Quadros Fagali

\section{Síndrome de Sotos: pesquisa de microdeleções e mutações intragênicas no gene NSD1}

Dissertação apresentada ao Instituto de Biociências da Universidade de São Paulo, para obtenção do título de Mestre em Biologia/Genética

Orientadora: Pra. Dra. Célia P. Koiffmann

São Paulo 
Fagali, Claudia Quadros

Síndrome de Sotos: pesquisa de microdeleções

e mutações intragênicas no gene NSD1

Dissertação de Mestrado - Instituto de Biociências da Universidade de São Paulo, Departamento de

Genética e Biologia Evolutiva.

1. Síndrome de Sotos

2. Gene NSD1

3. Cromossomo 5

4. Deleção

5. Mutação

Comissão Julgadora

Orientador 


\section{AGRADECIMENTOS}

À minha orientadora Dra Célia P. Koiffmann pela oportunidade, pela confiança, pelos estímulos, por todos os ensinamentos e por me ensinar a fazer ciências.

À FAPESP, pelo auxílio financeiro (Bolsa de Mestrado, Reserva Técnica), sem o qual este trabalho não teria sido realizado.

À Todos os médicos neurologistas, geneticistas, endocrinologista pelo encaminhamento de pacientes, particurlamente à Dra Chong Ae Kim e ao Dr Fernando Kok, pelos muitos pacientes encaminhados.

Aos pais e familiares dos pacientes, pela confiança no nosso trabalho.

Á Toninha pela ajuda na coleta de sangue.

Às meninas do genoma, Martha, Vanessa, Kátia, Kelly e Camila pela ajuda nas "corridas" e auxílio nas técnicas.

À todos os docentes e funcionários do departamento que de alguma forma me ajudaram neste período.

Às Dras Claudete H. Gonzalez, Luciana Hadaad e ao Dr. Paulo A. Otto, que participaram da minha qualificação, pelas sugestões.

Às amigas do laboratório Mariana, Ilana, Mônica, Cláudia, Rose, Cris, Carla, Estela e Lucilene por me ajudarem e me apoiarem durante todo esse processo. Agradeço à Mô e à Rô por me ensinar e sempre me ajudar com as técnicas de Biologia Molecular e pela amizade que construímos. À Mari por uma amizade que ultrapassa os muros da USP e por todas as etapas que passamos e sempre 
permanecemos juntas apoiando uma a outra. À llana pela grande amizade e por todas as dicas dadas. À Cláu por ter me ensinado as técnicas de citogenética e ter tido paciência comigo quando era estagiária. À Carla pela ajuda com as técnicas e conversas na hora do almoço. À Cris pelos bons papos e conselhos. À Estela pela tranqüilidade e sussego que me trouxe. À Lu por me ajudar com as confusões das notas fiscais, com todas as procuras das pastas e pelas "fofocas" de segunda de manhã. À todas vocês eu agradeço de coração por fazerem parte dessa etapa da minha vida.

Aos amigos Lílian, Fernando e Rafa por terem me mostrado caminhos quando eu achava que estava num beco sem saída.

À Bel pela amizade, apoio, paciências com as minhas bagunças e claro pelas cópias.

Aos meus amigos do coração Jairo, Caju, Renato, Nina, Denise, Yara, Washington, Desi, Simone, Ligia, Dani, Tati, Ana, Chris, Selma, Mirene, leta, Marilia e Dê pelas farras, risadas, choradeiras, carnavais e por me fazerem uma pessoa tão rica.

À minha família gigante querida por todas as alegrias, e em especial á Flá e a Lau, por torcerem pelo meu sucesso.

Ao meu irmão por toda uma vida cheia de histórias, pelo apoio e por torcer por mim.

Ao meu querido $\mathrm{Vi}$, mesmo tendo acompanhado só o final desse processo, agradeço por me apoiar, por acreditar em mim, por me animar quando estava desanimada, por me dar força quando acabava a pilha, mas o mais importante por ter me dado amor. 
E, principalmente, aos meus pais por tudo. Por acreditarem em mim, por terem me dado a oportunidade de virar a minha vida de ponta cabeça, pela preocupação, pelo apoio emocional e financeiro. À minha mãe pela herança acadêmica, pelos passeios e compras no shopping para espairecer. Ao meu pai pelas aulas de física, lá nos idos anos 90, e pelos almoços de domingo. E aos dois pelo amor e carinho que sempre me deram. 


\section{ÍNDICE}

I - INTRODUÇÃO............................................................ 1

I.1 - Síndromes de crescimento acelerado ........................................2

I.2 - Síndrome de Sotos (SoS) .................................................... 3

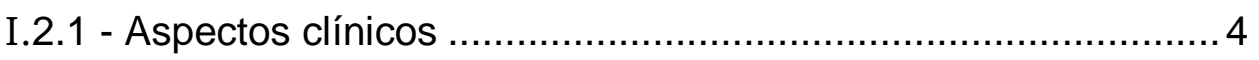

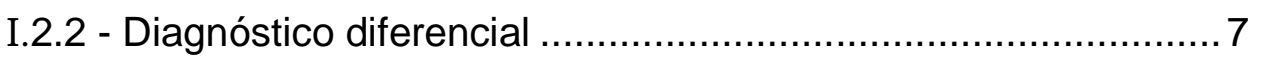

I.2.2.1 - Síndrome de Weaver (MIM 277590) ........................... 7

I.2.2.2 - Síndrome de Beckwith-Wiedemann (MIM 130650)........8

I.2.2.3 - Síndrome de Bannayan-Riley-Ruvalcaba (MIM153480) 11

I.2.2.4 - Simpson-Golabi-Behmel (MIM 312870) ....................... 14

I. 2.2.5 - Síndrome de Nevo (MIM 601451) ...................................... 17

I.2.2.6 - Síndrome de Proteus (MIM 176920) ............................. 17

I.2.3 - Aspectos Genéticos da síndrome de Sotos.........................20

I.2.4 - Correlação genótipo/fenótipo .......................................... 29

I.2.5 - Diagnóstico genético ................................................... 30

II. OBJETIVOS ..................................................................... 32

III. CASUÍSTICA E MÉTODOS ............................................. 34

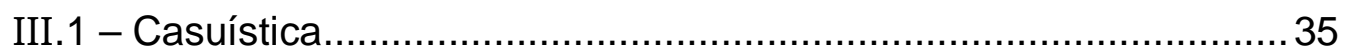

III. 2 - Métodos ......................................................................... 36

III.2.1 - Extração de DNA ............................................................ 36

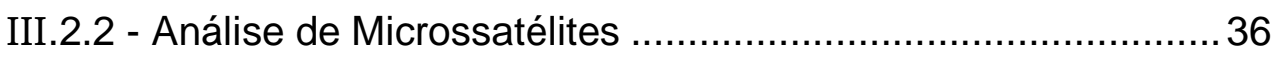

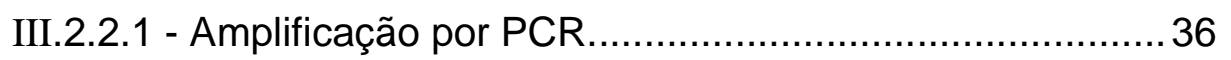

III.2.2.2 - Eletroforese em gel de agarose................................ 37

III.2.2.3 - Interpretação dos resultados .................................... 37

III.2.3 - Análise por MLPA ....................................................... 40

III.2.3.1 - Interpretação dos resultados .................................... 42

III.2.4 - Seqüenciamento direto do gene NSD1 ..........................43

III.2.4.1 - Amplificação por PCR ............................................ 43

III.2.4.2 - Eletroforese em gel de agarose............................. 44 


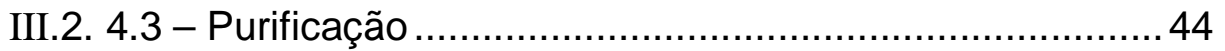

III.2.4.4 - Reação de seqüenciamento ........................................... 45

III.2.4.5 - Purificação pós-seqüenciamento................................. 45

III.2.4.5.1 - Purificação por precipitação com Acetato de Amônio

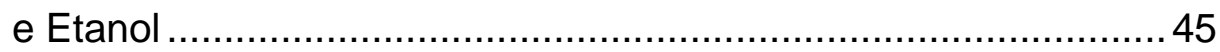

III.2.4.5.2 - Purificação utilizando Sephadex................................ 46

III.2.4.6 - Interpretação dos resultados ....................................... 48

IV - RESULTADOS ...................................................... 50

IV.1 - Análise molecular para identificação de deleções ..........................51

IV.1.2 - Análise por marcadores de Microssatélites ..........................51

IV.1.3 - Análise pela técnica de MLPA …………….......................52

IV.2 - Análise molecular para identificação de mutações .......................56

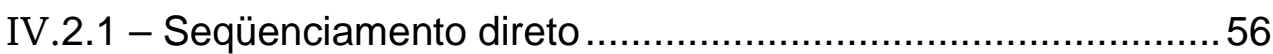

IV.3 - Achados Clínicos dos pacientes ............................................... 61

V - DisCUSSÃO .......................................................... 79

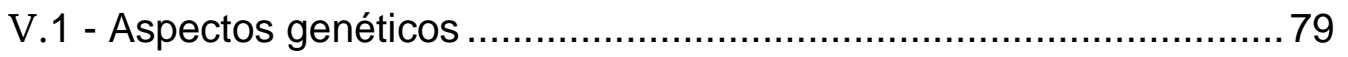

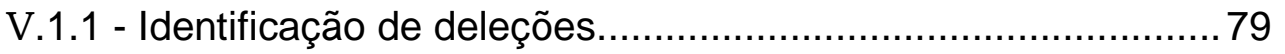

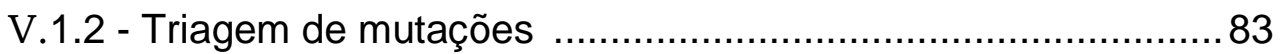

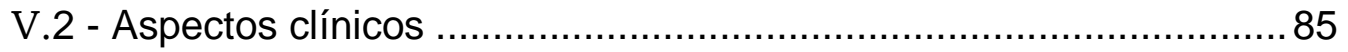

VI - RESUMO E CONCLUSÕES ........................................ 96

VII - ABSTRACT ......................................................... 100

VIII - ANEXOS................................................................. 102

VIII.1 - Ficha de Anamnese para a Síndrome de Sotos ....................... 103

VIII.2 - Ficha de Anamnese Geral ........................................................ 105

VIII.3 - Termo de Consentimento Livre Esclarecido ...............................111

VIII.4 - Tabela de Principais Características Fenotípicas e Comportamentais dos Pacientes Não Típicos .....................................113 
VIII.5 - Tabela das Freqüências das Características Fenotípicas e Comportamentais dos Pacientes Não Típicos ..................................... 122

VIII.6 - Foto dos Pacientes Não Típicos .............................................. 123

IX - Referências Bibliográficas .................................. 124 


\section{I - INTRODUÇÃO}

\section{I.1 - Síndromes de crescimento acelerado}

As síndromes de crescimento acelerado foram documentadas pela primeira vez no século 19. Condições como a síndrome de Beckwith-Wiedemann, síndrome de Sotos, entre outras, foram descritas na década de 60. Entretanto, essas síndromes de crescimento acelerado só começaram a ser estudadas, no campo clínico, no começo da década de 80 (Cohen, 1998). A partir de então, muitos estudos nesta área estão sendo realizados.

De um modo geral, as síndromes de crescimento acelerado compartilham algumas características comuns como: o crescimento acelerado pré e pós-natal, o peso que é tão importante quanto o comprimento; normalmente essas síndromes estão associadas a várias anomalias, a deficiência mental está freqüentemente presente e algumas dessas síndromes estão associadas a neoplasias. Na maioria dessas síndromes o crescimento acelerado está presente desde o nascimento (Cohen, 1989).

Na maior parte das vezes a síndrome resulta de uma hiperplasia (aumento do número de células), da hipertrofia (aumento do tamanho celular), do aumento do espaço intersticial (espaço dentro de tecidos ou órgãos), ou por uma combinação desses fatores (Cohen, 1998).

A associação de síndromes de crescimento acelerado com as neoplasias, principalmente as embrionárias, se explica pelo fato da divisão celular acelerada 
ser um pré-requisito para os dois processos. Isto é, tanto para o surgimento de neoplasias quanto para a ocorrência de síndromes de crescimento acelerado é necessário que haja uma divisão celular acelerada (Cohen, 1989). .

Em 1989, Cohen fez uma relação de todas as síndromes de crescimento acelerado conhecidas, são elas: Macrossomia Diabética, Gigantismo Infantil, síndrome de Beckwith-Wiedemann, Hemihiperplasia, síndrome de Sotos, síndrome de Nevo, síndrome de Bannayan-Riley-Ruvalcaba, síndrome de Weaver, síndrome de Marshall-Smith, síndrome Elajalde, síndrome de Simpson-GolabiBehmel, síndrome de Proteus. Dentre essas, apenas as síndromes de BeckwithWiedemann, Sotos, Bannayan-Riley-Ruvalcaba e Simpson-Golabi-Behmel têm seus genes e seus mecanismos genéticos descritos.

\section{I.2 - Síndrome de Sotos (SoS)}

A primeira descrição da síndrome de Sotos (MIM 117550) foi feita em 1964 por Sotos e colaboradores que descreveram cinco crianças que apresentavam crescimento acelerado, aspectos acromegálicos e anomalias cerebrais não progressivas com retardo mental. Palato alto e queixo proeminente também foram observados em vários desses pacientes. Além disso, a idade óssea estava avançada em todos os casos.

Em 1967, Hook e Reynolds descreveram que as crianças afetadas pela síndrome tinham mãos e pés grandes desde o nascimento e crescimento acelerado nos primeiros anos de vida, mas a altura final não era excessiva. Também apresentavam idade óssea avançada, prognatismo leve e uma leve 
dilatação dos ventrículos cerebrais. Convulsões e "déficit" de coordenação também foram observados.

Em 1987, Kaneko e colaboradores relataram defeitos congênitos nos pacientes típicos com a síndrome. Em 1990, Cole e Hughes descreveram que os aspectos da síndrome eram mais leves do que se acreditava e que esses aspectos tendiam a melhorar com a idade. Também em 1990, Gorlin e colaboradores estimaram um risco de $3,9 \%$ para os pacientes com SoS desenvolverem tumores malignos ou benignos, o mesmo risco que existe nas outras síndromes de crescimento acelerado.

Cole e Hughes, em 1994, após revisão das características clínicas da síndrome sugeriram os critérios de diagnósticos usados até hoje: a face típica, o crescimento acelerado, a idade óssea avançada e o atraso de desenvolvimento.

A incidência de SoS está estimada entre 1:10000 e 1:50000 nascimentos (Ambler, 2002).

\section{I.2.1 - Aspectos clínicos}

A síndrome de Sotos é caracterizada pelo crescimento acelerado pré e pósnatal e idade óssea avançada nos 4 a 5 primeiros anos de vida. Outras anomalias encontradas são o retardamento mental ou dificuldade de aprendizagem, a macrocefalia, fácies típica com testa proeminente, hipertelorismo, estrabismo, fissura palpebral antimongolóide, as orelhas grandes, o palato alto e estreito, mãos e pés grandes e possibilidade de erupção prematura dos dentes. É também freqüentemente associada com anomalias cerebrais, cardiovasculares e urinárias, 
e, ocasionalmente, é acompanhado por lesões malignas, como tumor de Wilms e hepatocarcinoma (Nagai et al, 2003; Ambler, 2002; Kamimura et al, 2003; Agwu et al, 1999). Com o avanço da idade, a face gradualmente se alonga, o queixo fica mais proeminente, a altura chega próxima ao normal e a macrocefalia não é mais pronunciada (Höglund et al, 2003).

Os aspectos neurológicos são variáveis e incluem hipotonia, dificuldade de alimentação e atraso no desenvolvimento motor e da linguagem, com tendência a melhorar com a idade. A média de QI é de 78, com uma variação de 40 a 129. Atraso para andar até depois de 15 meses e atraso na fala até depois dos 30 meses é comum nesta síndrome (Höglund et al, 2003; Cohen, 2003).

Convulsões são descritas em cerca de $50 \%$ dos casos e cerca de metade ocorre com febres altas. Sialorréia é também constantemente observada e o "déficit" de atenção pode ocorrer em alguns casos (Cohen, 2003). Já foi relatado também, em pacientes com a síndrome de Sotos, anormalidades como ausência de corpo caloso, sulco cortical proeminente, cavum septum pellucidum e cavum velum interpositi. Em estudo de neuroimagens foi encontrado proeminência do trigone e proeminência do lobo occipital e ventriculomegalia (Schaefer et al, 1997).

Problemas comportamentais e sociais são comuns com temperamento agressivo e imaturidade emocional. A fertilidade nos indivíduos afetados é normal (Ambler, 2002).

O diagnóstico clínico é baseado, principalmente, nas características faciais. Além dos aspectos faciais típicos os critérios usados são: a) a altura acima do percentil 97, b) o perímetro cefálico acima do percentil 97, c) a idade óssea avançada, d) o atraso de desenvolvimento e e) anomalias ou malformações 
congênitas (Douglas et al, 2003; Nagai et al, 2003). Entretanto, muitas características são não específicas, o que dificulta o diagnóstico.

Existem casos em que o paciente tem a maioria das características da síndrome de Sotos, mas Ihe faltam alguns critérios essenciais, como idade óssea avançada, ou crescimento acelerado moderado ou ausente. Nestes casos é dito que o paciente é portador de Sotos-Like (Douglas et al, 2003; Amiel et al, 2002). Ainda não se sabe se Sotos-Like é uma síndrome alélica à síndrome de Sotos ou se são geneticamente distintas (Amiel et al, 2002).

Já foram relatados, também, casos de gêmeos monozigóticos ambos com a síndrome e casos em que uma das crianças é portadora da síndrome e a outra não (Amiel et al, 2002; Brown et al, 1998).

Atraso na menarca, oligomenorreia, aumento na taxa de abortos espontâneos e natimortos foram relatados em pacientes com síndrome de Sotos (Douglas et al, 2003; Optiz et al, 1998).

A maioria dos casos de síndrome de Sotos é esporádica, mas em 1977, Zonnana e colaboradores descreveram 3 famílias que apresentavam transmissão vertical e o mesmo quadro clínico da síndrome. Smith e colaboradores observaram mãe e filha afetadas. Halal, em 1982, descreveu uma família em que o pai e os dois filhos homens eram afetados, e em 1985 Winship descreveu uma segunda família com o pai e 4 filhos homens, de diferentes mulheres, afetados. Goldstein, em 1988, sugeriu que o padrão de herança era autossômico dominante. Nas famílias afetadas, a probabilidade de progenitores afetados virem a ter outros filhos também afetados é de 50\%; este também é o risco para os futuros filhos de afetados (Miyao et al, 1998). 


\section{I.2.2 - Diagnóstico diferencial}

Há, também, uma grande sobreposição fenotípica entre a síndrome de Sotos e várias outras síndromes. As que são confundidas com mais freqüência são a síndrome de Weaver, síndrome de Bannayan-Riley-Ruvalcaba, síndrome de Beckwith-Wiedemann e macrocefalia familial benigna (Tatton-Brown \& Rahman, 2006).

Tatton-Brown, et al, (2005b) sugeriram que, apesar das sobreposições clínicas entre essas síndromes, as alterações no gene NSD1 são essencialmente específicas para a síndrome de Sotos e, por isso, o diagnóstico genético para qualquer caso em que haja alteração do gene NSD1, é o de síndrome de Sotos.

\section{I.2.2.1 - Síndrome de Weaver (MIM 277590)}

A síndrome que mais se sobrepõe à síndrome de Sotos é a síndrome de Weaver, que foi descrita pela primeira vez por Weaver e colaboradores, em 1974.

É caracterizada pelo crescimento acelerado, face característica, idade óssea avançada e atraso no desenvolvimento neuropsicomotor. A aparência facial é muito similar à aparência na síndrome de Sotos. Outras características desta síndrome são: choro rouco e fraco, unhas afundadas, dígitos proeminentes e camptodactilia (Douglas et al, 2003). Segundo Tatton-Brown e Rahman (2006), essas duas síndromes podem ser diferenciadas molecularmente, já que nenhum caso típico de síndrome de Weaver apresentou alterações no gene NSD1. 


\section{I.2.2.2 - Síndrome de Beckwith-Wiedemann (MIM 130650)}

A síndrome de Beckwith Wiedmann (BWS) foi descrita pela primeira vez em 1963 por Beckwith. Um ano depois, Wiedemann descreveu mais três casos adicionando novas características e, desde então, a síndrome passou a se chamar Beckwith-Wiedemann.

Sua incidência é de 1:13.700 nascidos. A maior parte dos casos, 85\%, é esporádico e o cariótipo é normal. Apenas cerca de $2 \%$ dos casos apresentam alterações cromossômicas, como translocações, inversões e duplicações. Aproximadamente $10 \%$ a $15 \%$ dos casos de BWS têm herança autossômica dominante com, preferencialmente, transmissão materna (Weksberg et al, 2005).

As características principais desta síndrome são o crescimento acelerado pré e pós-natal, a macroglossia, anomalias na orelha, mancha na testa, hipoglicemia neonatal, defeitos na parede abdominal (onfalocele, hérnia umbilical, diastase do reto), visceromegalia, problemas renais, hemihiperplasia e tumores embrionários (Weksberg et al, 2005; Lapuzina, 2005; Rahman, 2005).

A genética da BWS é complexa e envolve mutações ou alterações na expressão de vários genes associados ao ciclo celular e ao controle de crescimento que sofrem "imprinting" genômico na região cromossômica 11 p15.5 (Murrell, et al, 2004).

O principal mecanismo epigenético envolvido é o "imprinting" que é uma marcação diferencial de acordo com a origem parental, ocorrendo em $75 \%$ dos casos. Desses, $55 \%$ apresentam perda ou ganho de metilação e cerca de $20 \%$ apresentam dissomia uniparental paterna. Além disso, $\sim 10 \%$ dos casos são por 
mutação no gene CDKN1C; em 13-15\% dos casos ainda não se sabe a causa (Weksberg et al, 2005).

Uma das causas de BWS é a perda de imprinting em IGF-2. Esse gene tem expressão paterna e, deste modo, o alelo materno está silenciado. Outro gene envolvido neste mecanismo é o $H 19$ que, ao contrario do IGF-2, tem expressão materna e o alelo paterno está silenciado. Para regular esse mecanismo existe um centro de "imprinting" que no cromossomo materno não está metilado, enquanto que no cromossomo paterno está metilado (figura 1a) (Weksberg et al, 2005).

Quando ocorre um erro e o centro de "imprinting" materno também fica metilado, o gene $H 19$ materno, que deveria ser expresso, vai ser silenciado e o IGF-2 materno que, deveria estar silenciado, vai ser expresso, resultando na expressão bialélica de IGF-2 e levando a BWS (figura 1b) (Weksberg et al, 2005).

Mecanismo semelhante pode ocorrer com os genes CDKN1C, KCNQ1, KCNQ1OT1 desta região (figura 1c) (Weksberg et al, 2005). Além desse mecanismo, pode ocorrer também dissomia uniparental paterna, ou seja, o individuo terá duas copias do cromossomo 11 p15 paterno e nenhuma contribuição materna (Cooper, et al, 2007).

Outro mecanismo que pode levar a esta síndrome é a mutação do gene CDKN1C (figura 1d). Nesse caso, o gene CDKN1C, quando sofre uma mutação no alelo materno (CDKN1C é expresso no cromossomo materno e silenciado no cromossomo paterno), deixará de se expressar e levará à BWS (Enklaar, et al, 2006; Weksberg et al, 2005).

Alguns casos de BWS não típicos apresentaram mutações no gene NSD1, tendo sido o diagnóstico baseado na hipoglicemia neonatal, presença de hérnia 
umbilical e alterações renais; entretanto essas características também ocorreram na síndrome de Sotos e as alterações renais são mais associadas à síndrome de Sotos do que a BWS (Tatton-Brown, et al, 2005b).

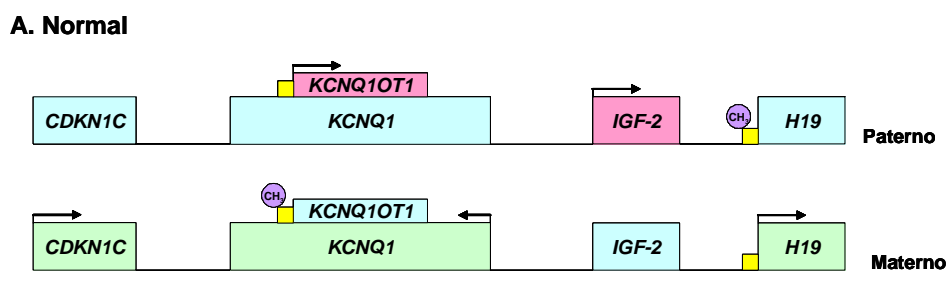

B. Perda de imprinting de IGF2

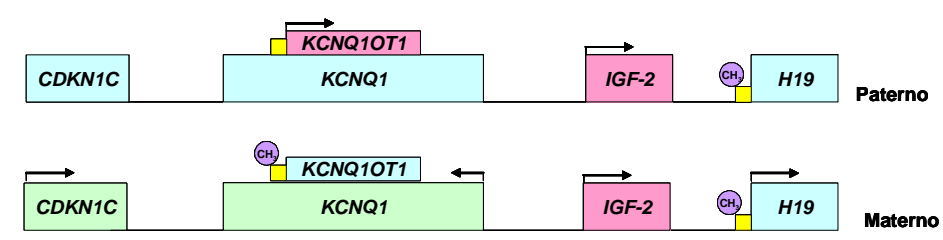

C. Perda de imprinting de KCNQ1

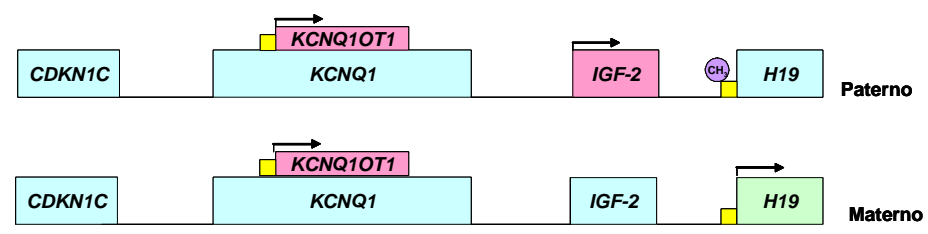

D. Mutação em CDKN1C

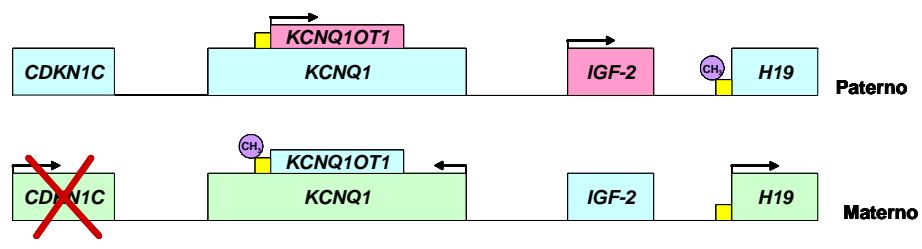

Figura 1: Mecanismos genéticos que causam BWS. A. Região $11 \mathrm{p} 15$ materna e paterna normais. O verde representa a expressão dos alelos maternos. O rosa representa a expressão dos alelos paternos. As setas representam a direção da transcrição. Em azul estão os genes imprintados não expressos. Em amarelo está a localização dos dois centros de "imprinting". O circulo roxo com radical $\mathrm{CH}_{3}$ representa a metilação do DNA.

B. Ganho de metilação no centro de "imprinting" 1, resultando em expressão bialélica de IGF-2 e perda de expressão de $\mathrm{H} 19$, isto é, duas cópias de IGF-2 com marcação paterna (expressas) e nenhuma cópia de H19 expressa. C. Perda de metilação no centro de "imprinting" 2 materno, resultando em duas cópias de CDKN1C e KCNQ1 não expressos, isto é, essa região materna fica com a marcação epigenética paterna. D. Representa mutação de gene CDKN1C. 


\section{I.2.2.3 - Síndrome de Bannayan-Riley-Ruvalcaba (MIM153480)}

Em 1960 Riley e Smith descreveram uma combinação de características, macrocefalia, pseudopapiledema e hemangioma. Ruvalcaba et al, em 1980 descreveram dois casos com macrocefalia, polipos intestinais e manchas café com leite no pênis. Essa síndrome foi chamada de Ruvalcaba-Myhre-Smith (Cohen, 1989).

Em 1971 Bannayan descreveu uma combinação de macrocefalia, lipomas múltiplos e hemangiomas e Zonana et al, em 1976 também descreveram a mesma condição. Até recentemente essas condições eram tratadas como diferentes síndromes, porém em 1988, Dvir et al, reconheceram que essas duas condições representavam a mesma síndrome. E em 1989 Cohen sugeriu chamar a síndrome de Bannayan-Riley-Ruvalcaba (BRRS) (Cohen, 1989).

As características principais desta síndrome são: a macrocefalia, o retardo mental, o atraso de desenvolvimento, maculas pigmentadas na glande do pênis (manchas café com leite), hemangiomas, lipomas e pólipos hamartomatosos. Também podem apresentar inclinação palpebral antimongoloide, estrabismo e ambliopia (Marsh, et al, 1999; Hendriks, et al, 2003).

BRRS é causada por mutações no gene PTEN (Phosphatase and Tensin Homolog), que está localizado no braço longo do cromossomo 10 na banda q23.3. Este gene tem nove exons e no exon 5 se encontra uma região que codifica um centro catalítico de fosfatase. O gene PTEN, então, codifica uma fosfatase supressora de tumor que age na via de sinalização PI3K/ PKB/AKT (via de 
proliferação e crescimento celular), resultando em apoptose e parada do ciclo celular (Waite, et al, 2002).

Um dos principais substratos endógenos da proteína PTEN é o fosfoinositol 3,4,5-trifosfato [Ptd-ins(3,4,5)P3] ou PIP3, que é um fosfolipídeo da via Fosfoinositol-3-quinase (PI3K), uma via importante na sinalização do crescimento celular (Marsh, et al, 1999; Waite, et al, 2002).

A ativação da PI3K, feita principalmente por fatores de crescimento, leva ao acúmulo de PIP3 nas membranas celulares, resultando na transferência do PKB/AKT dos armazéns citoplasmáticos para as membranas celulares. Nas membranas, o PKB/AKT sofre uma mudança conformacional e é fosforilado pela proteína quinase PDK1 (Waite, et al, 2002).

Para a ativação completa de PKB/AKT é necessário uma segunda fosforilação em seu "loop" hidrofóbico que contém uma serina. Essa PKB/AKT ativa permite, então, a fosforilação de um grande número de proteínas e, deste modo, representa um efetor chave na sinalização de PI3K (Hirsch, 2007).

A proteína PTEN antagoniza a via PI3K pela desfosforilação de PIP3, resultando na diminuição do transporte de PKB/AKT para as membranas celulares e, conseqüentemente, regula negativamente a ativação de AKT (figura 2) (Waite, et al, 2002).

Quando o gene PTEN sofre mutações ou está deletado, a desfosforilação de PIP3 em PIP2 não é catalisada, levando ao acúmulo de PIP3 nas células (Marsh, et al, 1999; Escudeiro, 2005). Este acúmulo ativa as quinases PKB/AKT, resultando no aumento da proliferação e crescimento celular na via PI3K (Marsh, et al, 1999). E, deste modo, pode levar à síndrome de Bannayan-Riley-Ruvalcaba. 


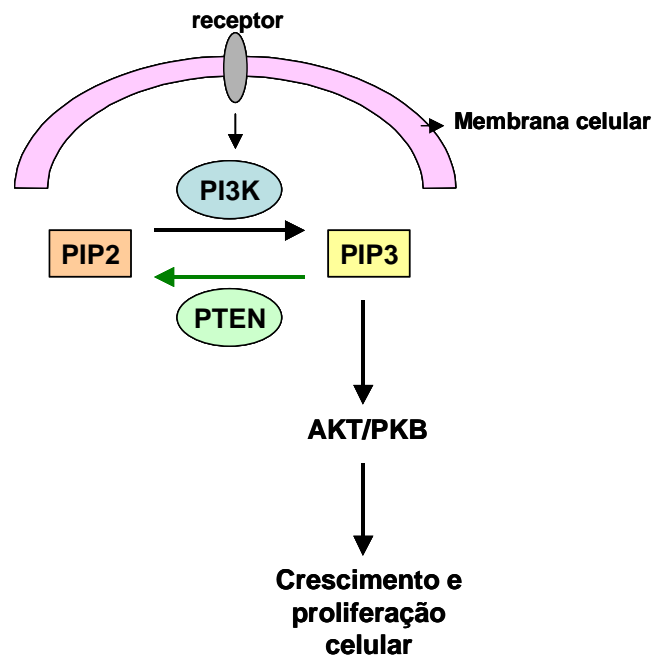

Figura 2: Esquema demonstrando a ativação da via PKB/AKT. Fatores de crescimento levados por um receptor de membrana (em cinza) ativam a PI3K (em azul), que transforma PIP2 (em laranja) em PIP3 (em amarelo). O PIP3 ativa a via AKT/PKB resultando em crescimento e proliferação celular. O gene PTEN (em verde) transforma o PIP3 em PIP2, regulando a via.

A síndrome de Bannayan-Riley Ruvalcaba mostra uma grande sobreposição clínica e molecular com a síndrome de Cowden (CS) (Pezzolesi, 2006). As principais características da CS são a macrocefalia, hamartomas múltiplos, papilomatose oral, hiperqueratose palmoplantar, tumores benignos do folículo capilar, tumores da tireóide e câncer de mama (Hendriks, et al, 2003).

Tanto em BRRS quanto em CS, a maioria das mutações no gene PTEN ocorre no exon 5 , onde se encontra o centro catalítico que codifica a fosfatase supressora de tumor. Depois do exon 5 , um segundo "hot spot" foi observado no exon 7 e 8 . Acredita-se que esses exons codificam potenciais sítios de fosforilação de tirosina quinase (Marsh, et al, 1999). 
Também foram encontradas mutações idênticas nas duas síndromes. Acredita-se que BRRS e CS são variações alélicas e fenotípicas da mesma síndrome. Além disso, em alguns casos de BRRS os pacientes desenvolveram características de CS quando mais velhos (Marsh, et al, 1999; Hendricks, et al, 2003).

Devido à sobreposição genética e fenotípica com a síndrome de Cowden é necessário uma atenção maior ao aumento do risco de malignidades nos pacientes com BRRS com mutação no gene PTEN. Exames periódicos para câncer de mama, de tireóide, endometrial, das células renais e hamartomas intestinais são recomendados para esses pacientes (Hendricks, et al, 2003).

\section{I.2.2.4 - Simpson-Golabi-Behmel (MIM 312870)}

Em 1984 Golabi e Rosen relataram quatro homens com crescimento acelerado pré e pós-natal, com dano intelectual, manifestação de características faciais e uma variedade de outras anomalias. Descreveram também, uma mulher com manifestação parcial dessas características. No mesmo ano, Behmel, et al, descreveram uma família afetada com as mesmas características e chamaram a atenção para uma descrição de 1975, feita por Simpson, et al. Em 1988, Neri, et al, sugeriram que a síndrome Golabi-Rosen deveria ser chamada Simpson-GolabiBehmel (Cohen, 1989).

Simpson-Golabi-Behmel (SGBS) é uma síndrome de herança ligada ao cromossomo X que se caracteriza, principalmente, pelo crescimento acelerado pré 
e pós-natal, atraso de desenvolvimento neuropsicomotor, aspecto facial "rústico" (coarse), lábios e palato fendido, macroglossia, um sulco mediano no lábio inferior ou na língua, mamilos supranumerários e várias anomalias viscerais e esqueléticas, como defeitos cardíacos congênitos, hérnia no diafragma, rins aumentados ou displásicos e anomalias vertebrais e de costelas (Sakazume, et al, 2007).

Os pacientes com essa síndrome também têm um alto risco de desenvolver tumores embrionários como o tumor de Wilms durante a infância (Sakazume, et al, 2007). Expressão parcial da síndrome pode ser observada nas mulheres portadoras (Li, et al, 2001).

Dois padrões clínicos da síndrome foram descritos. Uma forma mais grave e uma manifestação mais leve. Cada forma compreende $50 \%$ dos casos. Na forma grave o paciente morre ainda no útero ou durante a infância. As causas mais comuns da morte prematura podem ser por parada cardíaca, devido aos defeitos cardíacos congênitos, pela hérnia no diafragma, septicemia grave, cor pulmonale ou hipoglicemia, devido ao aumento da produção de insulina. Já na forma menos grave, os indivíduos podem viver até a fase adulta (DeBaun, et al, 2001).

A síndrome é causada por mutações ou deleções no gene GPC3, que está localizado no braço longo do cromossomo X, na banda q26. O gene tem 8 exons e faz parte da família dos glipicans, codificando um proteoglicano de heparam sulfato de superfície celular. Membros dessa família funcionam como controle de crescimento do desenvolvimento e na interação de fatores de crescimento (Li, et al, 2001). 
Existem seis genes da família glipican, são eles: glypican/GPC1, cerebroglycan/GPC2, OCI-5 /GPC3, k-glypican/ GPC4, GPC5 e GPC6; cada um deles tem um padrão de desenvolvimento e expressão gênica tecido-específico (Li, et al, 2001).

Os proteoglicanos de heparam sulfato são proteínas substituídas por heparam sulfato, que são complexos polissacarídeos que interagem com a ligação da heparina com os fatores de crescimento e influenciam as atividades de sinalização desses fatores (Veugelers, et al, 2000).

Foi proposto um modelo em que a proteína glipican-3, codificada pelo gene GPC3, controla os níveis de IGF-2. Especificamente, o glipican-3 como o receptor de IGF-2 (IGF-2R) se liga diretamente em IGF-2 e normalmente media seu aumento e sua degradação. Entretanto, estudos subseqüentes não foram capazes de confirmar essa interação física direta entre IGF-2 e glipican-3 e camundongos deficientes em glipican-3 não parecem ter alterado os níveis de IGF-2. Embora não dê para concluir que glipican-3 não tenha relação com o funcionamento de IGFs, esses estudos sugerem que outras hipóteses devem ser consideradas (DeBaun, et al, 2001).

O glipican-3 é altamente expresso em tecidos mesodermais embrionários que são propensos ao crescimento acelerado em SGBS (Pilia, et al, 1996). Já a expressão em adultos é limitada na placenta, pulmão, ovário e glândula mamária (Li, et al, 2001).

As deleções e mutações em GPC3 que levam à síndrome foram identificadas em todos os exons e sem correlações específicas de genótipo/fenótipo ( $L i$, et al, 2001). 


\section{2.2.5 - Síndrome de Nevo (MIM 601451)}

A síndrome de Nevo foi descrita pela primeira vez em 1974 por Nevo e colaboradores. Tipicamente, a síndrome de Nevo apresenta anomalias cardíacas e urinárias, edema volar, contraturas de mãos e pés, juntas frouxas, cifose, punhos caídos, dedos fusiformes e, além de várias características fenotípicas em comum com a síndrome de Sotos (Kanemoto, et al, 2006).

Em uma paciente de 17 meses com algumas características da síndrome de Nevo foi detectada a deleção de $\sim 2,2 \mathrm{Mb}$ no gene NSD1, semelhante à dos pacientes com síndrome de Sotos, sugerindo que essas duas síndromes poderiam ser alélicas (Kanemoto,et al, 2006).

\section{I.2.2.6 - Síndrome de Proteus (MIM 176920)}

A síndrome de Proteus é caracterizada por muitos crescimentos acelerados desproporcionais e assimétricos de partes do corpo, particularmente envolvendo o esqueleto, "cerebriform connective tissue nevus" "nevi epidermal", mal formações vasculares e desregulação do tecido adiposo (Cohen, 2005).

O crescimento acelerado dos ossos e dos tecidos moles tende a estacionar depois da adolescência, embora haja algumas exceções(Cohen, 2005).

Seqüelas importantes na síndrome de Proteus incluem (1) a morte prematura em $20 \%$ dos casos, principalmente por "trombose venosa profunda", resultando em embolismo pulmonar. (2) Vários tumores (Cohen, 2005). 
Até o momento todos os casos de síndrome de Proteus foram esporádicos (Cohen, 2005).

Segundo Thiffault, et al, (2004) a base genética mais plausível da síndrome de Proteus é a hipotese do mosaicismo somático, embora nenhuma mutação somática em genes candidatos tenha sido relatada. Como mutações no gene PTEN de linhagens germinativas foram identificadas em indivíduos diagnosticados com a síndrome de Proteus, Thiffault, et al (2004) fizeram uma triagem, utilizando tecidos afetados e não afetados de seis pacientes com a síndrome, por sequenciamento direto do DNA genômico à procura de mutações somáticas ou em linhagens germinativas nos genes PTEN ou GPC3. Nenhuma mutação intraexônica foi identificada, indicando que nem o gene PTE, nem o gene GPC3 parecem ter papeis na etiologia da síndrome de Proteus.

Moretti-Ferreira, et al, (1995) elaboraram uma chave de diagnóstico (figura 3) a partir de 32 portadores de macrossomia e da revisão dos casos da literatura, para o auxilio ao geneticista clínico na escolha da hipótese diagnóstica. 

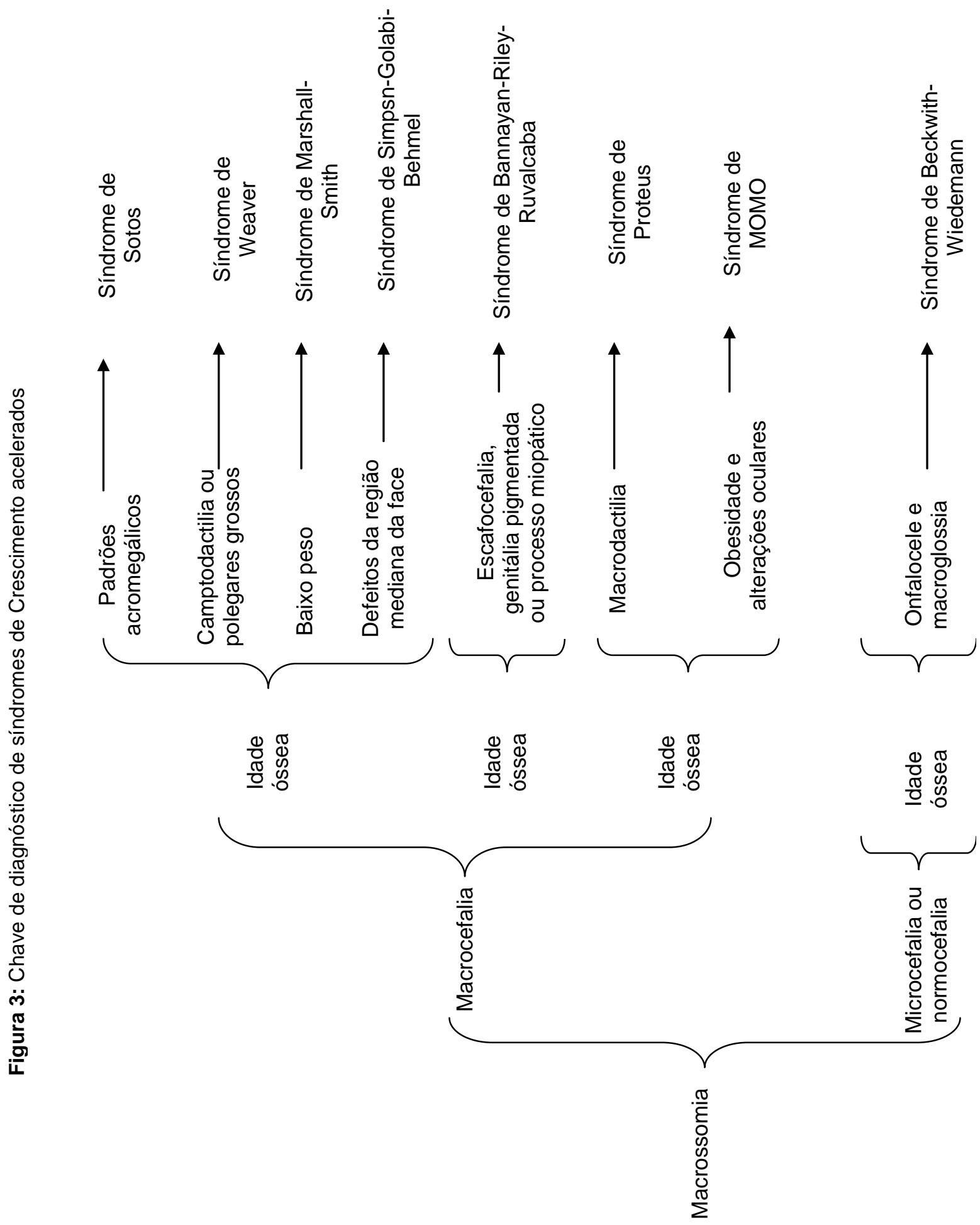


\section{I.2.3 - Aspectos Genéticos da síndrome de Sotos}

O gene NSD1 foi isolado por clonagem a partir do ponto de quebra, no braço longo do cromossomo 5 , em $5 q 35$, de paciente com translocação $t(5 ; 8)$ (q35;q24.1) (Höglund et al, 2003). Pela homologia com o gene Nsd1 de camundongos, observou-se que o gene humano é composto por 8552 bp, 8088 bp de matriz de leitura aberto (ORFs) e 23 exons. As ORFs começam no exon 2 e terminam no exon 23 e os tamanhos dos exons variam entre 76 bp (exon 9) e 2560 bp (exon 5) (Nagai et al, 2003; Kurotaki et al, 2001; Imaizumi et al, 2002).

O gene NSD1 tem dois transcritos diferentes que são observados tanto nos tecidos fetais como nos tecidos adultos. Esses transcritos, provavelmente, são devidos ao "splicing" alternativo do exon 3 e exon 4 como acontece no gene Nsd1 do camundongo (Kurotaki, et al, 2001). O transcrito 1, quando comparado com o transcrito 2, difere na 5' UTR e na região codificadora. Ele tem 9 kb e codifica a isoforma "a", que tem um N-terminal diferente da isoforma "b".

O transcrito 2 é o transcrito maior com $10 \mathrm{~kb}$ e codifica a isoforma "b" que é maior que a isoforma "a". Aparentemente as duas isoformas têm a mesma função.

Foi encontrado, também por homologia ao Nsd1 do camundongo, 8 regiões que codificam domínios funcionais: 2 domínios de interação com receptores nucleares (NID-L e NID+L) e mais 6 domínios: SET (su(var)3-9, enhancer-of-zeste, trithorax), PWWP (proline-tryptophan-tryptophan-proline) I e II, e, PHD (plant homeodomain protein) I, II e III, que são, possivelmente, associados às funções e à arquitetura da cromatina como reguladores transcricionais (figura 4). Todas 
essas regiões são conservadas entre os genes NSD1 Humano e Nsd1 do camundongo (Kurotaki et al, 2001).

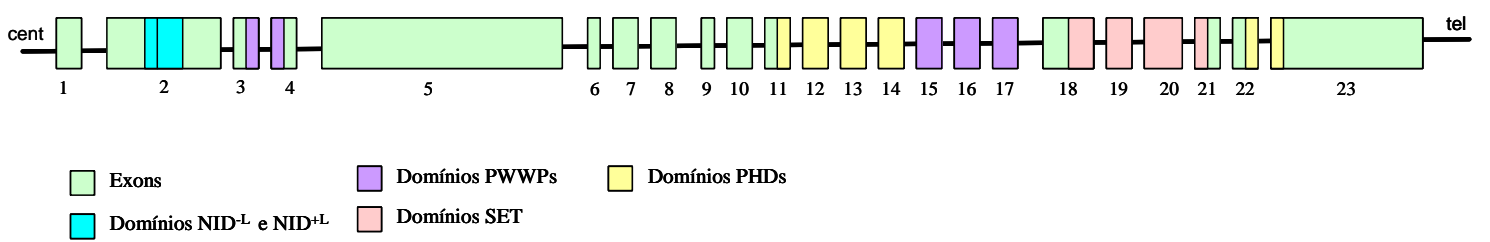

Figura 4: Gene NSD1 Humano e suas regiões codificadoras dos domínios funcionais SET (su(var)3-9, enhancer-of-zeste, trithorax), PWWP I e II, e, PHD I, II e III

O gene NSD1 é membro de uma família de genes que inclui mais dois membros: O gene NSD2 que está localizado no cromossomo 4p16, e o gene NSD3, mapeado no cromossomo 8p12 (Douglas, et al, 2005a).

O gene NSD2 foi isolado a partir da região crítica da síndrome de WolfHirschhorn (MIM 194190) e do ponto de quebra da translocação (4:14) de um paciente com mielomas múltiplos. Os genes NSD1, NSD2 e NSD3 apresentam grande similaridade de seqüências, particularmente na região 3’ da proteína e compartilham todos os domínios, exceto os dois domínios NID-L e NID+L, apenas presente no gene NSD1. O gene NSD2 apresenta $75 \%$ de homologia com o gene NSD1 em relação aos nucleotídeos. Já o gene NSD3 tem 70\% de identidade com o gene NSD1 e é muito expresso em linhagens de células tumorais (Kurotaki, et al, 2001; Douglas, et al, 2005a).

Com base nessas características, alguns autores sugeriram que a proteína NSD1 exerça duas funções, a de co-repressora e de co-ativadora da transcrição, a partir de dois domínios de interação de receptores nucleares, o NID ${ }^{-L}$ e $N^{+L}$, 
ambos agindo como co-repressor e co-ativador pela interação direta com o domínio de ligação ao ligante do receptor nuclear (Jenuwein et al, 1998; Aasland et al, 1995; Stec et al, 2000).

O processo de transcrição é regulado por muitos tipos de receptores nucleares. Esses receptores são membros de uma superfamília de fatores de transcrição de seqüências específicas, que atuam em diversos papeis como no controle do crescimento e da diferenciação celular, desenvolvimento e homeostase pela estimulação ou repressão da expressão de um gene alvo.

A partir da ligação a um ligante cognato hidrofóbico, como os esteróides e hormônios tiroidianos, os receptores nucleares modulam a transcrição através de recrutamento de várias proteínas co-fatoras, chamadas co-repressoras e coativadoras (Rayasam et al, 2003; Huang et al, 1998).

As co-repressoras, que são recrutadas na ausência do ligante, fazem parte de um complexo de múltiplas histonas desascetilase, que estabilizam a estrutura da cromatina e reprimem a transcrição. Já o recrutamento das co-ativadoras é dependente do ligante. As co-ativadoras possuem ou recrutam histonas acetiltransferases e histonas metiltransferases, que são capazes de remodelar/modificar a cromatina, enquanto outros complexos de recrutamento de ligantes parecem agir mais diretamente na maquinaria basal da transcrição (Rayasam et al, 2003).

Para realizar a função de co-fatora de transcrição a proteína NSD1 utiliza dois domínios funcionais $\mathrm{NID}^{-\mathrm{L}}$ e $\mathrm{NID}^{+\mathrm{L}}$. $\mathrm{NID}^{-\mathrm{L}}$ se liga aos receptores nucleares de ácido retinóico (RAR) e hormônio tiroidiano (TR) na ausência do ligante, mas não na sua presença. Enquanto que, $\mathrm{NID}^{+\mathrm{L}}$ pode se ligar aos receptores nucleares de 
ácido retinóico (RAR), de hormônio tiroidiano (TR), de ácido retinóico $X(R X R)$ e de estrógeno (ER) estritamente na presença do ligante (Huang, et al, 1998).

A proteina NSD1 parece agir como co-repressora e como co-ativadora tanto para TR e RAR na ausência do ligante, quanto para RXR, ER, RAR e TR na presença do ligante (Huang, et al, 1998).

Deste modo, NSD1 pode ser um fator intermediário de receptores nucleares altamente versátil, controlando a transcrição tanto negativamente como positivamente, dependendo do contexto do promotor do gene alvo e também do contexto celular em relação a outros fatores de interação com NSD1 (Huang, et al, 1998).

A expressão do gene NSD1 ocorre em vários tecidos, incluindo tecido cerebral de fetos e adultos, tecidos dos rins, muscular esquelético, baço e timo (Nagai et al, 2003).

A haploinsuficiência, que pode ser causada tanto por mutações de ponto como por microdeleções é a principal causa da síndrome de Sotos (Kurotaki, 2002).

As mutações que são a principal causa de SoS entre os eurodescendentes, são, normalmente, mutações de novo. Essas mutações parecem estar distribuídas por toda a região codificadora do gene NSD1 e com base nos dados obtidos até agora não há presença de "hotspots" (Kamimura et al, 2003; Melchior et al, 2005). Vários tipos de mutações foram encontradas no gene NSD1, como inserções, deleções, mutações "missense" e "nonsense" (Kamimura et al, 2003). 
Já as deleções, que podem ser parciais (até 1 exon) ou envolvendo todo o gene e regiões flanqueadoras, são a causa mais comum entre os japoneses. Dois terços destes pacientes têm uma deleção comum de $\sim 2,2 \mathrm{Mb}$, envolvendo todo o gene NSD1 e outros genes adjacentes (Miyake et al, 2003).

Essas deleções comuns podem ocorrer como conseqüência da presença de duas LCR (low copy repeats) encontradas nos pontos de quebra, uma proximal ou centromérica (SoS-PREP) e outra distal ou telomérica (SoS-DREP) (Kurotaki, et al, 2005).

As LCRs são seqüências repetitivas de DNA maiores que $1 \mathrm{~kb}$ com homologia acima de $90 \%$, e servem como substrato para a recombinação homóloga não-alélica (NAHR) (Kurotaki, 2005).

A recombinação homóloga não alélica é o principal mecanismo causador de "doenças genômicas". Ocorre entre essas LCRs, podendo levar a translocações não equilibradas, deleções, duplicações e inversões, dependendo da localização e da disposição das LCRs (Stankiewicz e Lupski, 2002) (figura 5).

\section{LCRs de direções opostas}

A

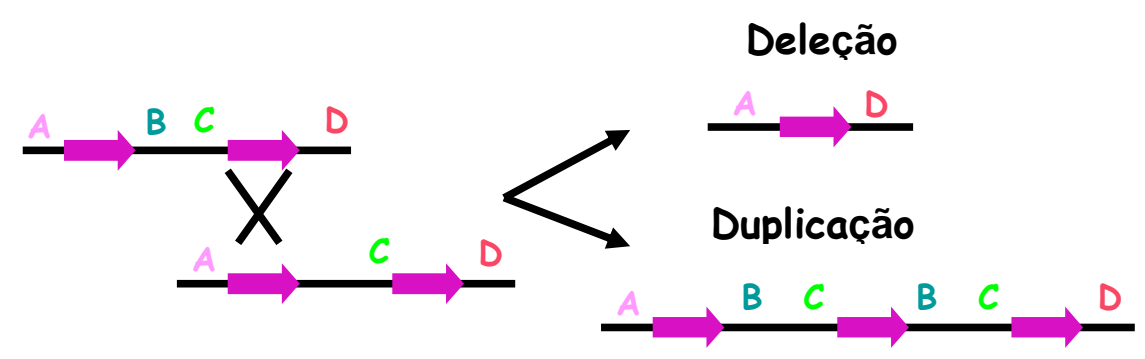




\section{Translocação recíproca}

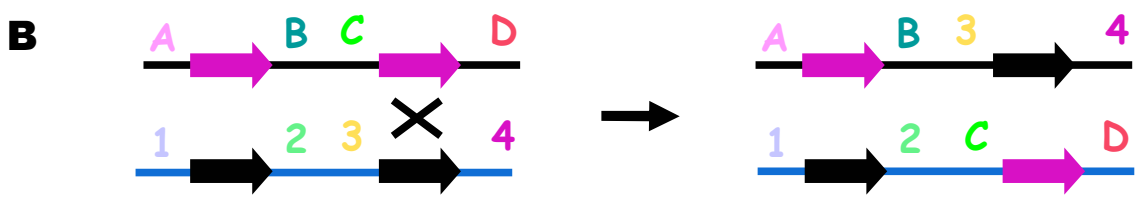

\section{LCRs de direções opostas}

C

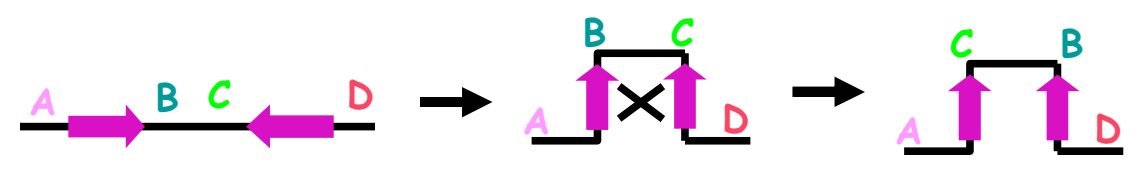

Figura 5: (modificado de Shaffer e Lupski) Recombinação Homologa não Alélica. A: LCRs de mesma direção em cromátides diferentes, resultando em duplicação ou deleção. B: LCRs de mesma direção em cromossomos diferentes, resultando translocação recíproca. C: LCRs de direções opostas na mesma cromátide, resultando em inversão.

As LCRs, centromérica e telomérica, do gene NSD1 têm uma estrutura em mosaico e sua orientação é invertida. Mas, uma inversão da subunidade 2B da LCR telomérica pode ocorrer, predispondo à deleção por recombinação homóloga não alélica, como mostra a figura 6 (Kurotaki, et al, 2005).

Esse polimorfismo é muito freqüente entre os japoneses, explicando a alta freqüência (66\%) das deleções entre esses pacientes.

Sempre que uma deleção ocorre por recombinação homóloga não alélica, também ocorre uma duplicação (figura 5a). A deleção de NSD1, como sabemos, resulta em SoS. A duplicação da parte distal de $5 q$ já é bastante estudada e é, 
principalmente, associada á baixa estatura, retardo mental, microcefalia, estrabismo, micrognatia, defeitos cardíacos (Chen, et al 2006).

Recentemente, Chen e colaboradores (2006) descreveram um caso de uma duplicação da região 5q35.2-5q35.3 (região de NSD1), com baixa estatura, microcefalia, face pequena oval, testa pequena, dificuldade de aprendizagem, atraso no desenvolvimento motor. Esse caso evidencia que o gene NSD1 tem efeito de dosagem: quando está em haploinsuficiência causa SoS e quando duplicado resulta em um fenótipo oposto.

A.

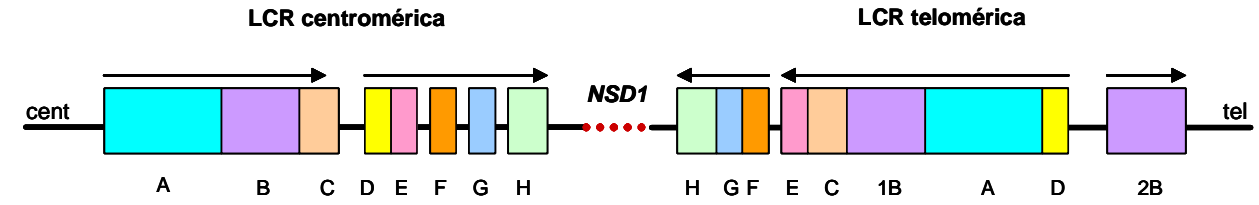

B.

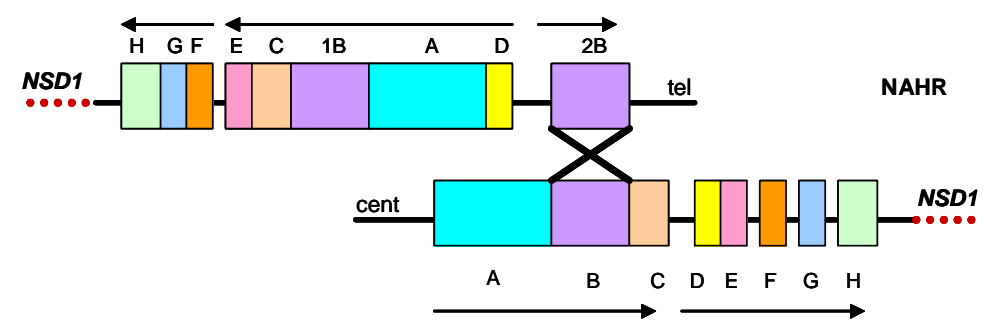

C.

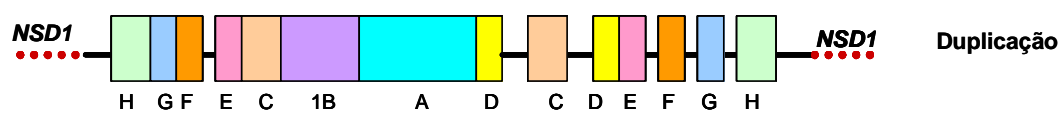

D.

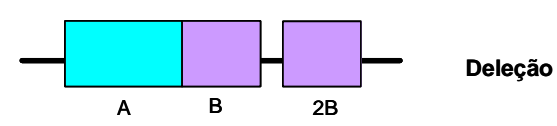

Figura 6: Esquema mostrando a recombinação homóloga não alélica entre as duas LCRs em NSD1. A. LCR centromérica e LCR telomérica. As setas indicam a direção das LCRs. B. Pareamento entre as subunidades 2B da LCR telomérica e 2 da LCR centromérica, que resulta em uma duplicação (C) e uma deleção (D). 
Outros pontos de quebra, diferentes dos pontos de quebra da deleção comum, não estão localizados dentro de elementos repetitivos. Entretanto, um elemento LINE 1 foi encontrado próximo ao ponto de quebra, sugerindo uma instabilidade genômica nestes locais (Visser, et al, 2005).

Outra causa provável para as deleções parciais do gene NSD1 é a recombinação entre seqüências Alu (Tatton-Brown, et al, 2005a).

Elementos Alu são seqüências repetitivas móveis, dispersas por todo genoma. É a repetição mais abundante; são derivados ancestrais do gene 7SLRNA que forma parte do complexo ribossômico. Deste modo, a origem de mais de 1.1 milhões de elementos Alu, que estão dispersos por todo o genoma humano, pode ter surgido a partir de uma duplicação gênica no início da evolução dos primatas e da subseqüente e contínua amplificação desses elementos (Batzer e Deininger, 2002).

O gene $N S D 1$ é rico em seqüências Alu com uma densidade de 40,2\% comparado com a de 10,6\% do genoma. Particularmente, o intron 2 contém 115 elementos Alu. Apesar dessa grande quantidade de seqüências repetitivas, algumas deleções não foram mediadas por essas seqüências. Nestes casos, o mecanismo proposto foi o da "junção das extremidades não homólogas" (NHEJ) pela observação de pouca homologia entre as seqüências flanquedoras dos pontos de quebra (Douglas, et al, 2005b).

A junção das extremidades não homólogas utiliza duas seqüências não homólogas como substrato para recombinação. Após a deleção de parte destas seqüências e do fragmento situado entre elas, estas seqüências são unidas com a 
adição de bases na junção da deleção devido ao mecanismo de reparo do DNA (figura 7) (Shaw e Lupski, 2004).

Além dessas causas, também foram descritos dois casos de síndrome de Sotos com duplicações de exons do gene NSD1. Em um deles a paciente era portadora de uma duplicação do exon 4 e no outro caso, a duplicação envolvia o exon 10 (Waggoner et al, 2005; Saugier-Veber et al, 2007).

As microdeleções na síndrome de Sotos são na maioria de origem paterna. Essa preferência pelo cromossomo paterno poderia ser explicada, segundo Myiake, et al, (2003), por uma maior susceptibilidade desta região, que sofre a deleção, do cromossomo paterno à rearranjos cromossômicos anormais.

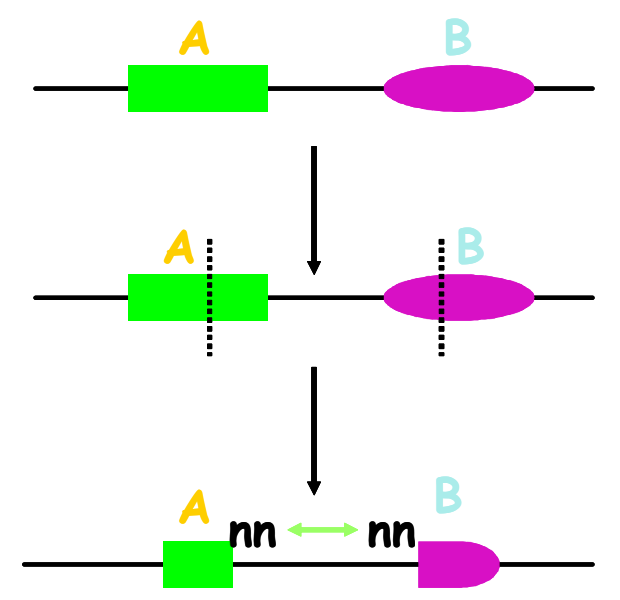

Figura 7: (modificado de Shaffer e Lupski 2004) NHEJ entre duas seqüências não homólogas $A$ e B. As duas seqüências são unidas, ocorrendo a deleção do segmento entre elas. Bases adicionais são inseridas no fragmento de junção da deleção. 


\section{I.2.4 - Correlação genótipo/fenótipo}

Algumas diferenças entre os fenótipos de pacientes com síndrome de Sotos portadores de microdeleções e mutações foram descritas. Em geral, os pacientes com mutações têm crescimento acelerado, maturação avançada (idade óssea avançada e erupção prematura dos dentes) na infância, retardamento mental leve a moderado, hipotonia e hiperreflexia. Já os pacientes com microdeleção têm perfil de crescimento e maturação similar, embora tendam a ser menores, com retardamento mental mais grave, atraso de desenvolvimento motor grave e podem apresentar aspectos autistas (Nagai et al, 2003; Rio et al, 2003).

Além disso, as anomalias do sistema nervoso central, cardiovascular e urinário são predominantes nos pacientes com a microdeleção, provavelmente pela deleção de genes adjacentes (Miyake, et al, 2003; Saugier-Veber, et al, 2007).

O fenótipo também pode variar entre os pacientes com mutações que têm a proteína truncada ou não truncada. Os pacientes com a proteína não truncada têm um quadro da síndrome mais leve do que os que têm a proteína truncada: frequentemente o perímetro cefálico é normal, pouca incidência de convulsões, menor dificuldade de aprendizagem. Além disso, são essas as mutações que estão presentes na maior parte dos casos familiais (Saugier-Veber, et al, 2007).

Ainda é incerto o porquê dessas diferenças, que tanto podem ser causadas por perturbações em genes relevantes da região deletada, quanto por variações genéticas, ou ambientais (Nagai et al, 2003). 
Há uma relação entre os pacientes com síndrome de Sotos portadores de mutações ou deleções heterozigotas no gene NSD1 e o sistema IGF-1. As alterações neste gene podem resultar em um aumento da bioatividade de IGF-1, levando ao crescimento acelerado da síndrome de Sotos (Boer et al, 2004).

Essa relação acontece devido à proteína NSD1 poder agir tanto como corepressora, quanto como ativadora de um grupo de hormônios nucleares receptores para genes promotores de crescimento (hormônio receptor tiroidiano, receptor de estrogênio, receptor de ácido retinóico) pela interação com o domínio de ligação ao ligante, na ausência ou presença do ligante (Boer et al, 2004).

As aberrações endócrinas e parácrinas no sistema IGF-1 de pacientes com alterações no gene NSD1 podem ser conseqüências diretas da transcrição alterada do gene pelo hormônio receptor nuclear (Boer et al, 2004).

\section{I.2.5 - Diagnóstico genético}

Um dos meios de identificação de mutações intragênicas e deleções no gene NSD1 foi descrito por Melchior et al (2005) que estabeleceram um protocolo de identificação utilizando o escaneamento por dHPLC (Denaturing High Performance Liquid Chromatography), combinado com o real-time quantitative PCR. Este protocolo também identifica polimorfismos no gene NSD1.

Outra técnica para a deteç̧ão dessas mutações é a do sequênciamento direto dos exons 2 a 23 e seus introns flanqueadores, cobrindo toda a região codificadora do gene NSD1 (Nagai et al, 2003). 
Já para a identificação das microdeleções podem ser realizadas analises de FISH (Fluorescence in situ Hybridization), com sondas específicas para NSD1 e para as regiões flanqueadoras do gene (Nagai et al, 2003). Outra forma de detecção é a analise por marcadores polimórficos de microssatélites dentro e ao redor do gene NSD1 (Douglas et al, 2003). Além da identificação pela técnica de MLPA (Multiplex Ligation Dependent Probe Amplification), que usa o Kit Salsa P026B, contendo sondas para os todos os exons (1 a 23) do gene NSD1, sondas para os genes FGFR4, FLT4 e TRIM52 e mais 16 sondas controles (Schouten, et al, 2002; Tatton-Brown et al, 2005a). 
- Detectar a presença de microdeleções na região 5q35 em pacientes com suspeita diagnóstica de Síndrome de Sotos.

- Analisar as correlações genótipo-fenótipo, relacionando as deleções genéticas com o quadro clínico.

- Detectar a presença de mutações na região $5 q 35$ em pacientes com suspeita diagnóstica de Síndrome de Sotos e relacionar com o quadro clínico.

- $\quad$ Sugerir critérios mínimos de diagnóstico clínico.

- Esse projeto visa também o diagnóstico diferencial, prognóstico e aconselhamento genético aos progenitores e familiares dos afetados. 


\section{CAsuística e MÉTOdos}

\section{III.1 - Casuística}

A casuística é composta por 65 pacientes com suspeita de diagnóstico clínico da Síndrome de Sotos e seus genitores encaminhados principalmente pelo Instituto da Criança HC-FMUSP (Dra. Chong A. Kim), Serviço de Neurologia Infantil do Hospital das Clínicas (Dr. Fernando Kok) e também por médicos de outras entidades assistenciais.

Os pacientes encaminhados para a análise molecular foram avaliados através de anamnese genético-clínica, na qual constam dados gestacionais, familiais e fenotípicos para ajudar na caracterização da síndrome (em anexo).

Os genitores ou responsáveis pelo paciente assinaram um Termo de Consentimento Livre Esclarecido, aprovado pelo Comitê de Ética em Pesquisa Seres Humanos (IBUSP), protocolo número 032/2005, autorizando o uso do material genético para a pesquisa (em anexo).

Os 65 pacientes foram analisados pela técnica de MLPA. Os genitores dos afetados também foram testados pela mesma técnica.

Trinta pacientes foram selecionados pelas suas características clínicas típicas para pesquisa de mutações no gene NSD1. 


\section{III.2 - Métodos}

A análise molecular consta das seguintes etapas: extração do DNA, análise de marcadores de microssatélites, análise por MLPA e seqüenciamento.

\section{III.2.1- Extração de DNA}

O DNA genômico dos pacientes e dos progenitores foram extraídos pelo Autopure LS (Gentra Systems) a partir de leucócitos do sangue periférico.

\section{III.2.2 - Análise de Microssatélites}

Para a análise de microssatélites foi utilizado um "primer" intragênico, SOT3, descrito por Douglas et al, (2003).

\section{III.2.2.1 - Amplificação por PCR}

A amplificação por PCR é realizada utilizando 4,35 $\mu \mathrm{l}$ de água mili-Q; $1 \mu \mathrm{l}$ de tampão; $1 \mu \mathrm{l}$ de dNTPs; 0,6 $\mu \mathrm{l}$ de cada primer (F' e R'); $0,3 \mu \mathrm{l}$ de $\mathrm{MgCl} ; 0,15 \mu \mathrm{l}$ de Taq polimerase e $2 \mu \mathrm{l}$ de DNA dos pacientes e progenitores, totalizando um volume final de $10 \mu$ l. Essa reação é amplificada em um termociclador usando um protocolo "touchdown" de $68^{\circ} \mathrm{C}$ a $50^{\circ} \mathrm{C}$. 


\section{III.2.2.2 - Eletroforese em gel de agarose}

Um gel de agarose $2 \%$ é utilizado para correr os fragmentos amplificados por PCR, confirmando o funcionamento da reação com a temperatura de hibridação testada. São utilizados $5 \mu \mathrm{l}$ da amostra de PCR e como padrão de concentração, emprega-se 100pb ladder (Pharmacia $\left.{ }^{\circledR}\right)$. A eletroforese é realizada sob a voltagem constante de 100 volts por aproximadamente 15 minutos.

Depois de confirmados os produtos amplificados por PCR são diluídos com $14 \mu \mathrm{l}$ de água mili-Q para $1 \mu \mathrm{l}$ da reação. Dessa reação diluída é retirado $2 \mu \mathrm{l}$ e

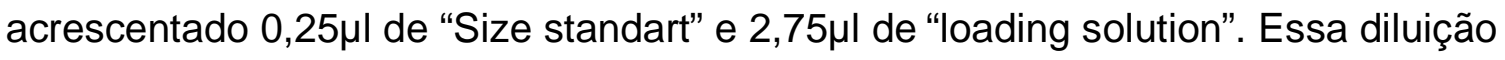
então é submetida a eletroforese em um seqüenciador e os resultados armazenados em um banco de dados no computador.

\section{III.2.2.3 - Interpretação dos resultados}

Os resultados são fornecidos por picos de fluorescência, que representam alelos identificados pelo tamanho do fragmento amplificado. A interpretação é baseada no padrão de herança dos alelos de microssatélites encontrados na criança em relação aos seus genitores.

Considera-se herança biparental do lócus quando ocorre a presença de dois picos na criança, um de origem materna e outro de origem paterna (Figura 8). 


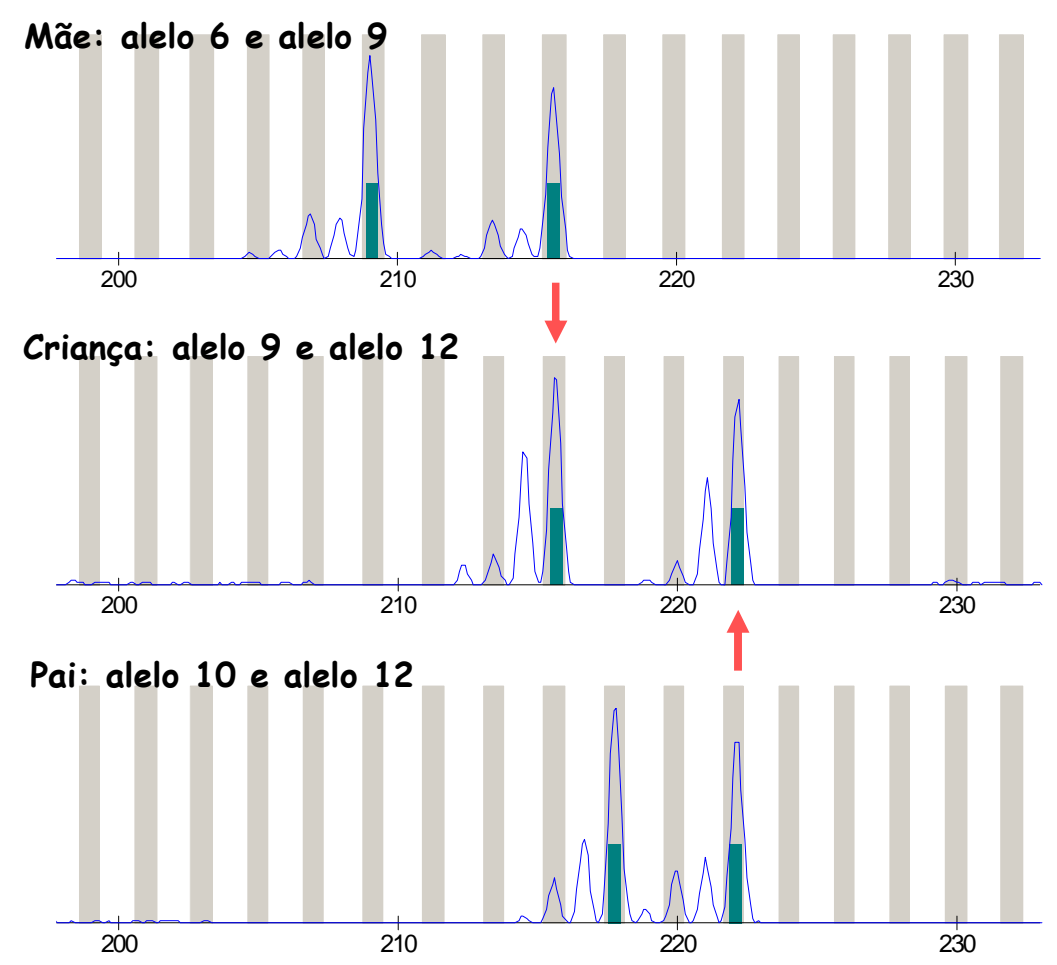

Figura 8: Herança biparental. A criança apresenta o alelo 9 herdado da mãe e o alelo 12 herdado do pai.

A presença de um único pico na criança, que também está presente em cada um dos progenitores não permite fazer a distinção entre a homozigose do locus (ou seja, herança de dois alelos, cada um proveniente de cada genitor) da hemizigose (herança de um único alelo), resulta em uma análise não informativa (Figura 9). 

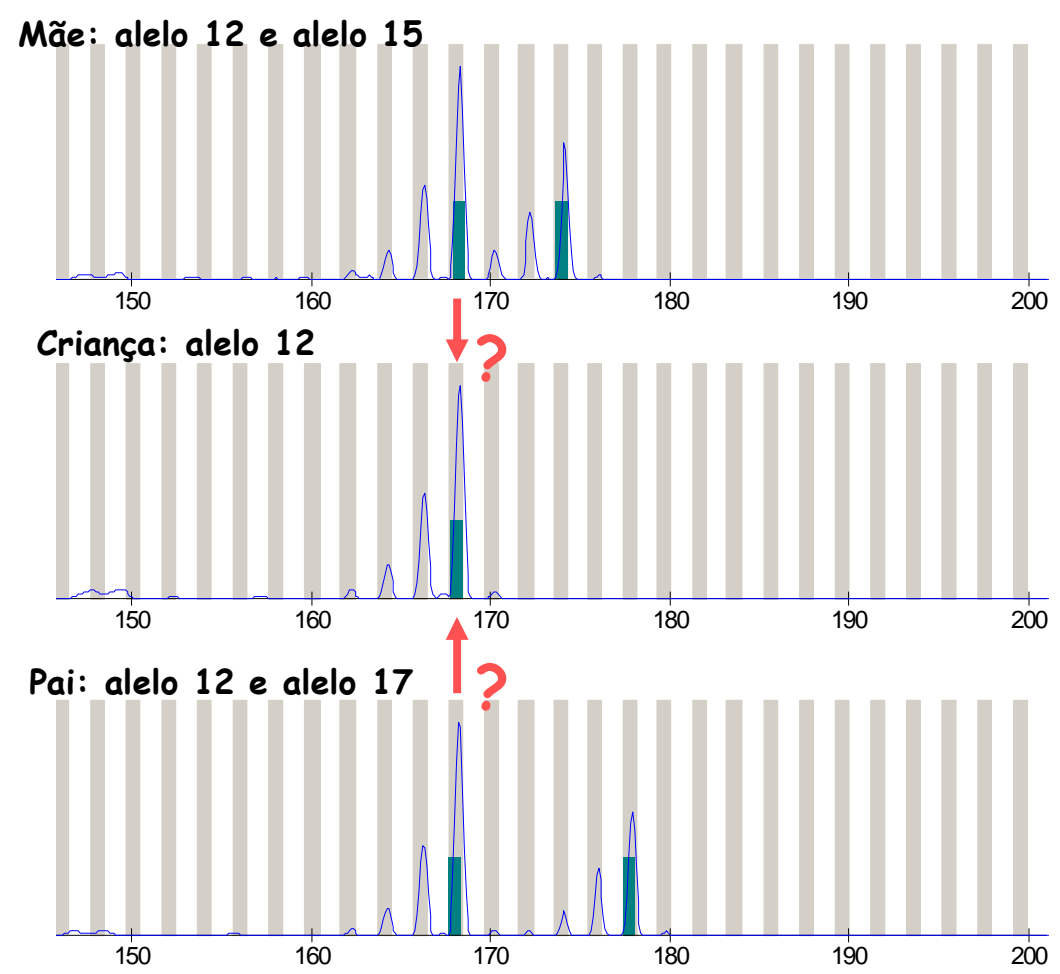

Figura 9: Resultado não informativo. A criança apresenta o alelo 12, que também está presente em ambos genitores, não sendo possível fazer a distinção entre a homozigose do locus (ou seja, herança de dois alelos, cada um proveniente de cada progenitor) da hemizigose.

A presença de um único pico na criança que está presente em apenas um dos genitores (no caso a mãe); e ausente no outro genitor, que não contribui com um alelo, nos dá o diagnóstico de deleção do lócus (Figura 10). 

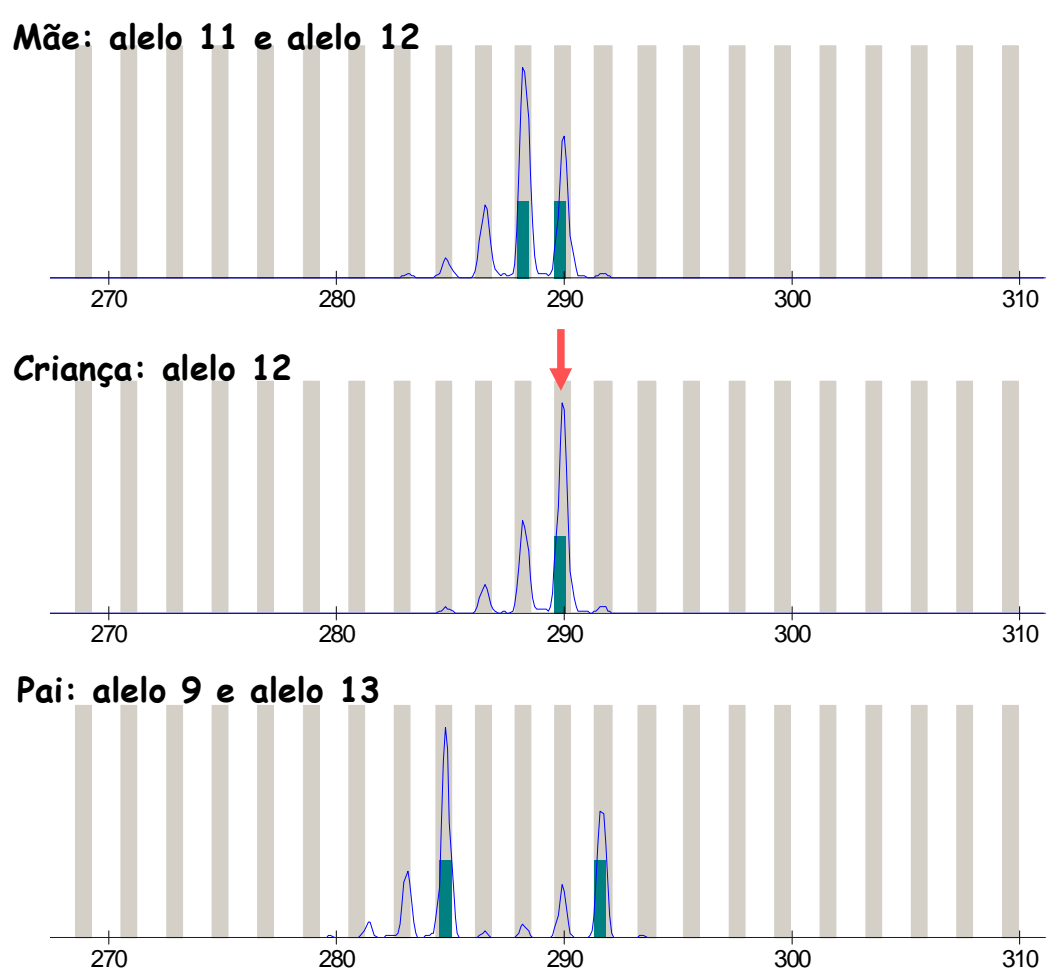

Figura 10: Deleção. A criança herdou o alelo 12 da mãe e o pai não contribuiu com um alelo.

\section{III.2.3 - Análise por MLPA}

A MLPA (multiplex ligation-dependent probe amplification) é uma técnica descrita por Schouten, et al, (2002) que permite a identificação de deleções e duplicações a partir de sondas de seqüências alvos, que são hibridadas no DNA genômico. A MLPA tem a vantagem de ser rápida e simples, e de baixo custo comparada com outras técnicas, como FISH (Hibridação in situ Fluorescente).

A análise por MLPA é feita a partir de um Kit (Salsa MLPA P026B) contendo uma sonda para cada exon do gene NSD1 (exon 2 a 23), exceto pelo exon 1 que contém duas sondas. Duas sondas para o gene FGFR4, com localização proxima 
ao promotor de $N S D 1$; duas sondas perto do telomero $5 \mathrm{q}$, as sondas dos genes FLT4 e TRIM52; e 16 sondas controles.

O protocolo para MLPA é dividido em dois dias. No primeiro dia, o DNA é quantificado e diluído para $50 \mathrm{ng} / \mu \mathrm{l}$ em volume total de 50 ou $25 \mu \mathrm{l}$ com TE. Após a diluição são adicionados $5 \mu \mathrm{l}$ deste DNA em tubos de $0,2 \mathrm{ml}$. Os tubos são colocados no termociclador no programa MLPA-Den $\left(98^{\circ} \mathrm{C}\right.$ por 5 minutos, $2^{\circ} \mathrm{C}$ "for ever"). Enquanto o DNA está na máquina, é preparada a solução de anelamento (1,5 $\mu \mathrm{l}$ probe mix, 1,5 $\mu \mathrm{l}$ de Buffer para cada reação). Quando o programa MLPA-Den termina, o DNA é retirado da máquina, são adicionados $3 \mu \mathrm{l}$ de solução de anelamento em cada tubo e os tubos voltam para a máquina no programa MLPA-Ann (95' $\mathrm{C}$ por 1 minuto e $60^{\circ} \mathrm{C}$ "for ev er"). Deixa overnight (por 16 horas).

No segundo dia, a solução Máster Mix (3 $\mu$ l de ligase Buffer A, $3 \mu$ l de ligase Buffer $B, 25 \mu$ de água mili-Q e $1 \mu$ l de ligase para cada reação) é preparada. $A$ ligase só é acrescentada na hora de adicionar a solução aos tubos. Completada as 16 horas no programa MLPA-Ann o "instant incubation" é ligado à $54^{\circ} \mathrm{C}$. A ligase é acrescentada ao Máster Mix e com os tubos ainda na máquina são adicionados $32 \mu \mathrm{l}$ da solução. O programa de PCR MLPA-Lig (54C por 15 minutos, $98^{\circ} \mathrm{C}$ por 5 minutos, $4^{\circ}$ "for ver") é ligado. Neste intervalo, a solução Máster Mix I (4 $\mu$ I PCR Buffer e $26 \mu$ l água mili-Q para cada reação) é preparada e $30 \mu$ desta solução são acrescentados em novos tubos. A solução Máster Mix II $(2 \mu$ l enzyme dilution Buffer, $2 \mu$ Primer, 5,5 $\mu$ lágua mili-Q, 0,5 $\mu$ la enzima Taq polimerase para cada reação) também é preparada; a Taq polimerase só será 
adicionada quando a solução Máster Mix II for acrescentada às reações. Terminado o programa MLPA-Lig, os tubos são retirados da máquina e são adicionados $10 \mu \mathrm{l}$ desta reação nos tubos novos com a solução Máster Mix I. Esses novos tubos são colocados na máquina em "intant incubation" à $60^{\circ} \mathrm{C}$. A enzima Taq polimerase é acrescentado à solução Máster Mix II e $10 \mu$ lesta solução são adicionados às reações que estão na máquina. O programa MLPAPCR $\left(95^{\circ} \mathrm{C}\right.$ por 30 segundos, $60^{\circ} \mathrm{C}$ por 30 segundos, $72^{\circ} \mathrm{C}$ por 1 minuto -32 ciclos $-4^{\circ} \mathrm{C}$ "for ever") é ligado. A seguir, os tub os são retirados da máquina e $1 \mu \mathrm{l}$ de cada reação é diluido com $0,25 \mu$ de "Size Standart" e $7 \mu$ de "louding solution". Essas diluições, então, são submetidas à eletroforese em um seqüenciador e os resultados armazenados em um banco de dados no computador.

\section{III.2.3.1 - Interpretação dos resultados}

Os resultados são obtidos por picos de fluorescência analisados a partir do programa Fragment Profile. Cada pico corresponde ao quociente de dosagem (DQ) de cada sonda amplificada. A interpretação dos picos se dá pela comparação dos tamanhos dos picos dos pacientes com os picos dos indivíduos controles. Se os picos forem do mesmo tamanho entre o paciente e o controle significa que o DQ é normal, ou seja, o paciente não tem a deleção. Se o pico do paciente tiver aproximadamente metade do tamanho do pico controle, então este 
paciente tem uma deleção desta seqüência alvo. Mas se o pico do paciente for maior, então ele apresenta uma duplicação desta sonda.

Para melhor confiabilidade dos resultados foi desenvolvido um programa para análise de MLPA criado em Excel (NGRL, Manchester Analysis Sheets). Este programa utiliza a média obtida do quociente de dosagem de cada produto da amplificação. Um DQ normal representa o indivíduo diplóide (2n) e tem o valor próximo a 1. Deste modo, a presença de duas cópias da seqüência alvo da sonda no DNA genômico pode variar de aproximadamente 0,85 a 1,15. Se a seqüência estiver com apenas uma cópia (haplóide - n) a variação é de aproximadamente 0,35 a 0,65 e três cópias da seqüência alvo (3n) o DQ normal é aumentado em uma vez e meia e a variação é de cerca de 1,35 a 1,65.

\section{III.2.4 - Sequenciamento direto do gene NSD1}

Para o sequenciamento direto foram utilizados 4 pares de "primers" do exon 5 do gene NSD1, descrito por Douglas et al, (2003).

\section{III.2.4.1 - Amplificação por PCR}

A amplificação por PCR é realizada utilizando $8,5 \mu$ de água, $12,5 \mu \mathrm{l}$ de Máster Mix, $1 \mu$ de cada "primer" (F e R) e $2 \mu$ de DNA dos pacientes e progenitores, totalizando um volume final de $25 \mu \mathrm{l}$. Essa reação é amplificada em um termociclador usando um protocolo "touchdown" de $67^{\circ} \mathrm{C}$ a $50^{\circ} \mathrm{C}$. 


\section{III.2.4.2 - Eletroforese em gel de agarose}

Um gel de agarose $2 \%$ é utilizado para correr os fragmentos amplificados por PCR, confirmando o funcionamento da reação com a temperatura de hibridação testada. São utilizados $2 \mu l$ da amostra de PCR e como padrão de concentração, emprega-se 100pb ladder (Pharmacia $\left.{ }^{\circledR}\right)$. A eletroforese é realizada sob a voltagem constante de 100 volts por aproximadamente 15 minutos.

\section{III.2. 4.3 - Purificação}

Para a purificação do PCR foi utilizado o GFX PCR DNA and Gel Band Purifications Kit (Amersham Biosciences), que mostrou ser mais eficiente e mais rápido do que a purificação por enzimas.

Para cada amostra a ser purificada, uma coluna GFX é colocada dentro de um tubo coletor. São adicionados $500 \mu \mathrm{l}$ de "capture buffer" em cada coluna e o produto do PCR é transferidao, misturando bem com o "Capture buffer". Essa solução é centrifuguada, em velocidade máxima, por 30 segundos. O filtrado é descartado esvaziando o tubo coletor, a coluna é colocada de volta ao seu respectivo tubo e são adicionados $500 \mu$ de "Wash buffer". Essa nova solução é centrifuguada mais uma vez, a velocidade máxima, por 30 segundos. O tubo coletor é descartado e a coluna é colocado em um novo tubo de 1,5 ml. São aplicados $30 \mu \mathrm{l}$ de água MiLiQ diretamente em cima da matriz de fibra de vidro da coluna. A amostra é incubada a temperatura ambiente por um minuto e a seguir é 
centrifuguada, a velocidade máxima, por um minuto para recuperar o produto de PCR purificado.

\section{III.2.4.4 - Reação de sequenciamento}

Nesta fase, os "primers" F e R são utilizados separadamente, cada "primer" é colocado em sua própria reação, dobrando a quantidade de amostras. Para a reação é utilizado $4 \mu \mathrm{l}$ de Prémix, $1 \mu \mathrm{l}$ do "primer" F ou $\mathrm{R}, 4 \mu \mathrm{l}$ do produto purificado de PCR e $1 \mu$ de água MiliQ, totalizando um volume de $10 \mu$ l. Essa reação é incubada no termociclador por $95^{\circ} \mathrm{C}$ por $20 \mathrm{seg}, 57^{\circ} \mathrm{C}^{*}$ por $15 \mathrm{seg}$ e $60^{\circ} \mathrm{C}$ por 1 min e 15 seg, em 30 ciclos. Depois é conservado a $4^{\circ} \mathrm{C}$ e no escuro.

* A temperatura de annealing que deve ser usada na reação de sequenciamento é a mesma que foi usada no programa de amplificação por PCR.

\section{III.2.4.5 - Purificação pós-sequenciamento}

A purificação após o sequenciamento pode ser realizada de duas formas: por precipitação com acetato de amônia e etanol ou utilizando o sephadex.

III.2.4.5.1 - Purificação por precipitação com Acetato de Amônio e Etanol

Primeiro é adicionado $1 \mathrm{uL}$ de Acetato de Amônio 7,5M e 28uL de Etanol 100\% a cada reação. Os tubos são agitados para homogeneizar. A concentração 
final do Etanol deve ser $70 \%$. Não é necessário utilizar etanol gelado ou incubar a baixas temperaturas para a precipitação. Os tubos são incubados à temperatura ambiente por 15 minutos (em ambiente escuro).

Os tubos são centrifugados à temperatura ambiente em microcentrífuga por 15 minutos em rotação máxima (aproximadamente 13.000 rpm). O sobrenadante é removido por aspiração (utilize micropipeta) e são adicionados 170uL de Etanol $70 \%$ para lavar o pellet. Essa nova solução é centrifugada novamente nas mesmas condições descritas anteriormente. O sobrenadante é retirado por aspiração e o pellet é deixado para secar ao ar (em ambiente escuro).

Por último, o pellet é diluído em 10uL de "Loading Solution", misturando bem e manter a $4^{\circ} \mathrm{C}$ protegido da luz.

III.2.4.5.2 - Purificação utilizando Sephadex

A purificação por sephadex é feita com reações de $10 \mu \mathrm{L}$. No caso da reação de sequenciamento ter menos que $10 \mu \mathrm{L}$, o volume deve ser completado com água MilliQ; depois é adicionado mais $5 \mu \mathrm{L}$ de água MiliQ em cada amostra, totalizando $15 \mu \mathrm{L}$.

Primeiro, é colocado um pouco de sephadex G-50 sobre um dos cantos do "Multiscreen column loader" (enchedor de colunas) e com o auxilio da espátula de acrílico que acompanha o enchedor, o sephadex é espalhado em todos os buraquinhos do mesmo. Todos os buracos devem ficar cheios, sem transbordar e sem sobrar espaço. 
Depois de cheio, a placa Multiscreen HV é encaixada sobre o enchedor de colunas de maneira que cada poço da placa corresponda a um poço do enchedor. O sephadex é transferido para a placa, virando o conjunto (placa + enchedor).

Com o sephadex transferido, são adicionados $300 \mu \mathrm{L}$ de água MilliQ em cada poço da placa. Com um filme plástico a placa Multiscreen é embrulhada e incubada por 3 horas à temperatura ambiente.

Passadas as três horas de incubação, uma placa de PCR de 96 orifícios é colocada embaixo da placa Multiscreen e presa com uma fita adesiva. O sephadex é centrifuguado à $650 \mathrm{~g}$ (2100 rpm na nossa centrifuga) por 5 minutos. $\mathrm{O}$ volume que passou para a placa coletora é descartado a placa Multiscreen é presa novamente à placa coletora com fita.

São acrescentados $140 \mu \mathrm{L}$ de água MilliQ em cada poço da placa Multiscreen e, novamente, é centrifugada a $650 \mathrm{~g}$ (2100 rpm na nossa centrifuga) por 5 minutos. O volume que passou para a placa coletora é descartado e novamente a placa Multiscreen é preza à placa coletora com fita.

Sem adicionar mais água, o conjunto (placa Multiscreen e placa coletora) é centrifugado a $650 \mathrm{~g}$ (2100 rpm na nossa centrifuga) por 2 minutos. A placa coletora é retirada e uma outra placa de PCR limpa é presa à placa Multiscreen.

O produto do sequenciamento é adicionado ao centro de cada poço da placa (colocar os $15 \mu \mathrm{L}$ sobre o sephadex) e é centrifugado novamente a $650 \mathrm{~g}$ (2100 rpm na nossa centrifuga) por 7 minutos. A placa Multiscreen é descartada (se a placa não tiver sido toda usada, marcar quais orifícios já foram usados, jogar 
somente o sephadex fora, tampar a placa e guardá-la apoiada num papel absorvente).

Essa diluição, então, é submetida à eletroforese em um seqüenciador e os resultados armazenados em um banco de dados no computador.

\section{III.2.4.6 - Interpretação dos resultados}

Os resultados são fornecidos por um eletroferograma, que representa graficamente o perfil do DNA. Os picos de fluorescência, do eletroferograma, são de quatro cores diferentes que representam as quatro bases nitrogenadas: adenina, timina, citosina e guanina (figura 11).

Quando há diferenças entre a seqüência de referência e a seqüência representada pelos picos, tanto na fita "forward" quanto na fita "reverse", há uma alteração nesta região, que pode indicar uma substituição, uma deleção ou uma inserção de base.

Pode ocorrer também a sobreposição de dois picos, que significa que temos uma heterozigose, ou seja, os dois nucleotídeos são representados simultaneamente, mas em cores diferentes (figura 12). 


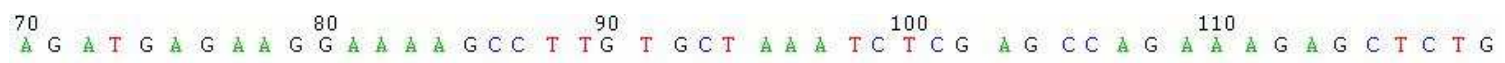

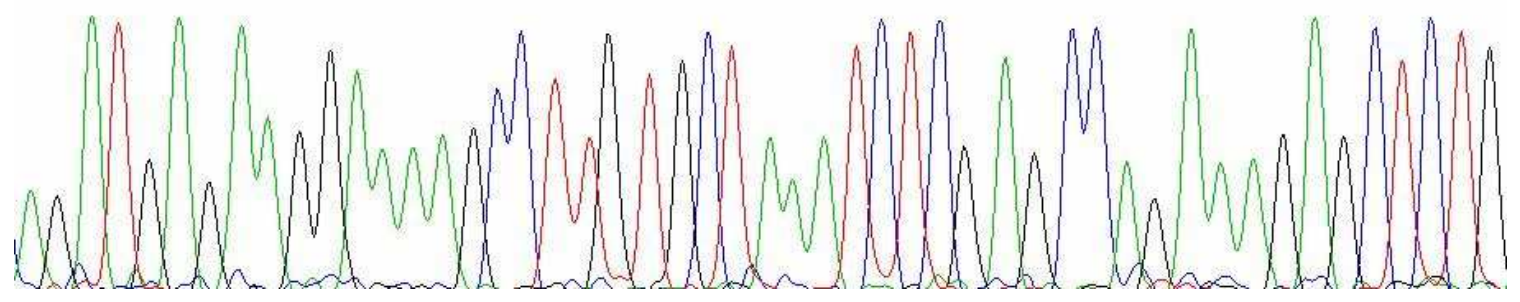

Figura 11: Eletroferograma representando as quatro bases nitrogenadas. Em verde a adenina; em preto a guanina; em vermelho a timina e em azul a citosina.

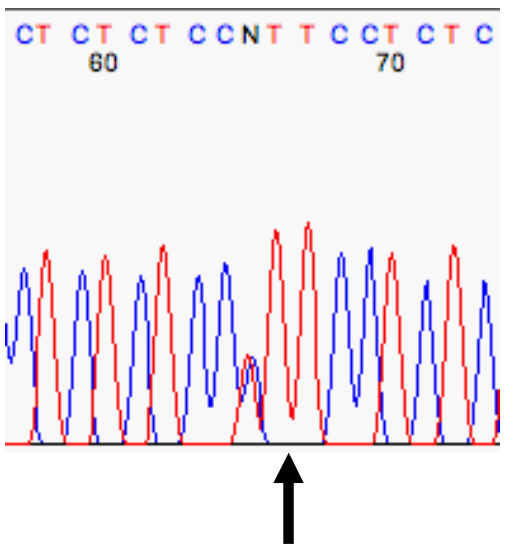

Figura 12: Representa um exemplo de um amplicon com um SNP em heterozigose. Neste caso um alelo é portador de um C, enquanto o outro tem um T. A seta mostra os dois picos presentes. 


\section{IV - RESUltAdOS}

\section{IV.1 - Análise molecular para identificação de delecões}

\section{IV.1.2 - Análise por marcadores de Microssatélites}

Dos 65 pacientes, 34 foram testados utilizando marcadores de microssatélites para a investigação de deleções do gene NSD1. Dos 34 pacientes apenas um foi identificado com deleção (figura 13). Em sete indivíduos o resultado foi não informativo e nos outros 26 a microdeleção foi excluída pela presença de dois alelos (herança biparental).

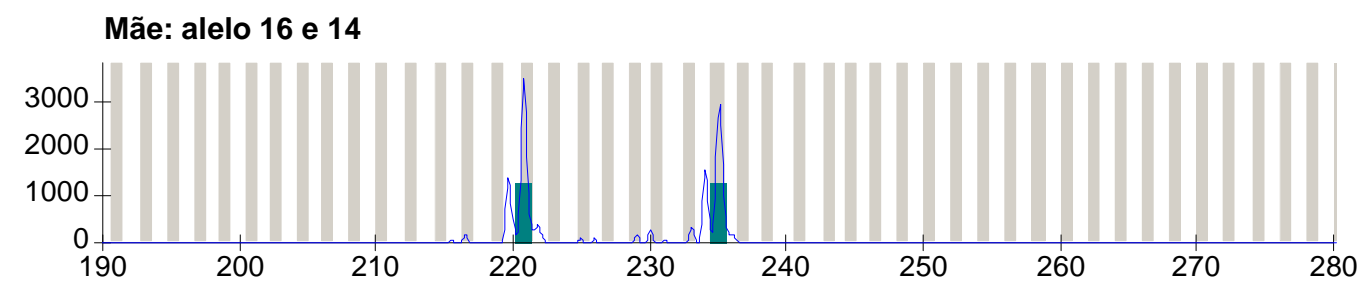

Pai: alelo 4 e 21
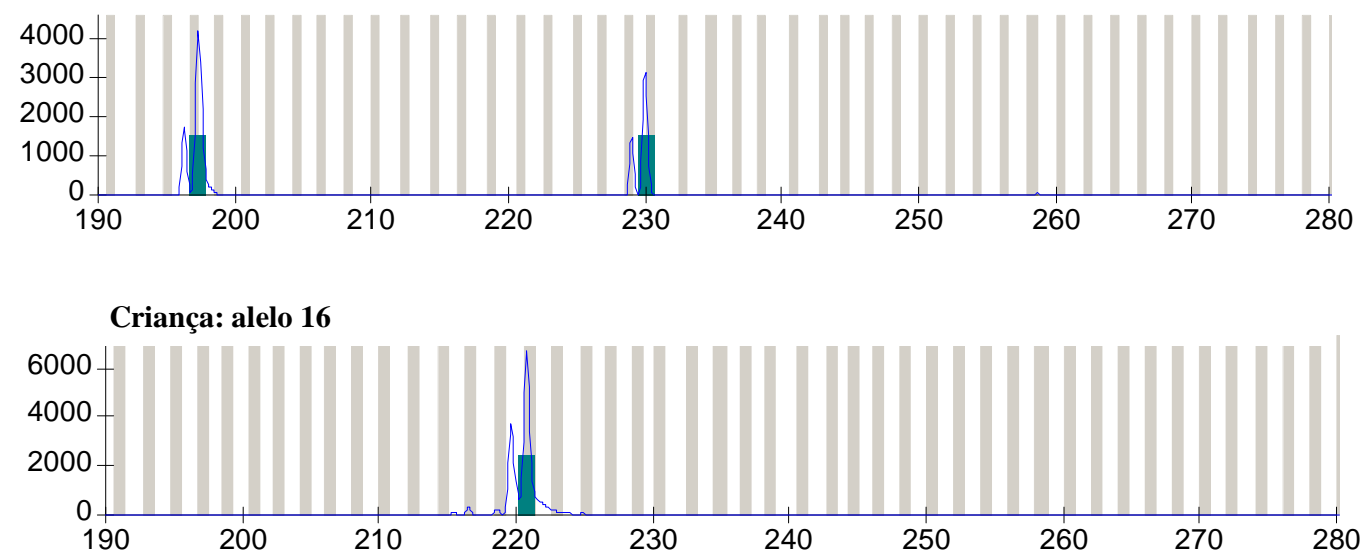

Figura 13: Paciente 28 apresenta apenas o alelo 16, que corresponde ao alelo materno, não apresentando nenhum alelo paterno. 


\section{IV.1.3 - Análise pela técnica de MLPA}

Pela análise de MLPA, os 65 pacientes foram testados, inclusive o paciente 28, com a deleção já identificada; nesse paciente foi confirmada a deleção de todo o gene NSD1, assim como a deleção do gene FGFR4, que fica aproximadamente a $35 \mathrm{~Kb}$ de NSD1 (figura 14).
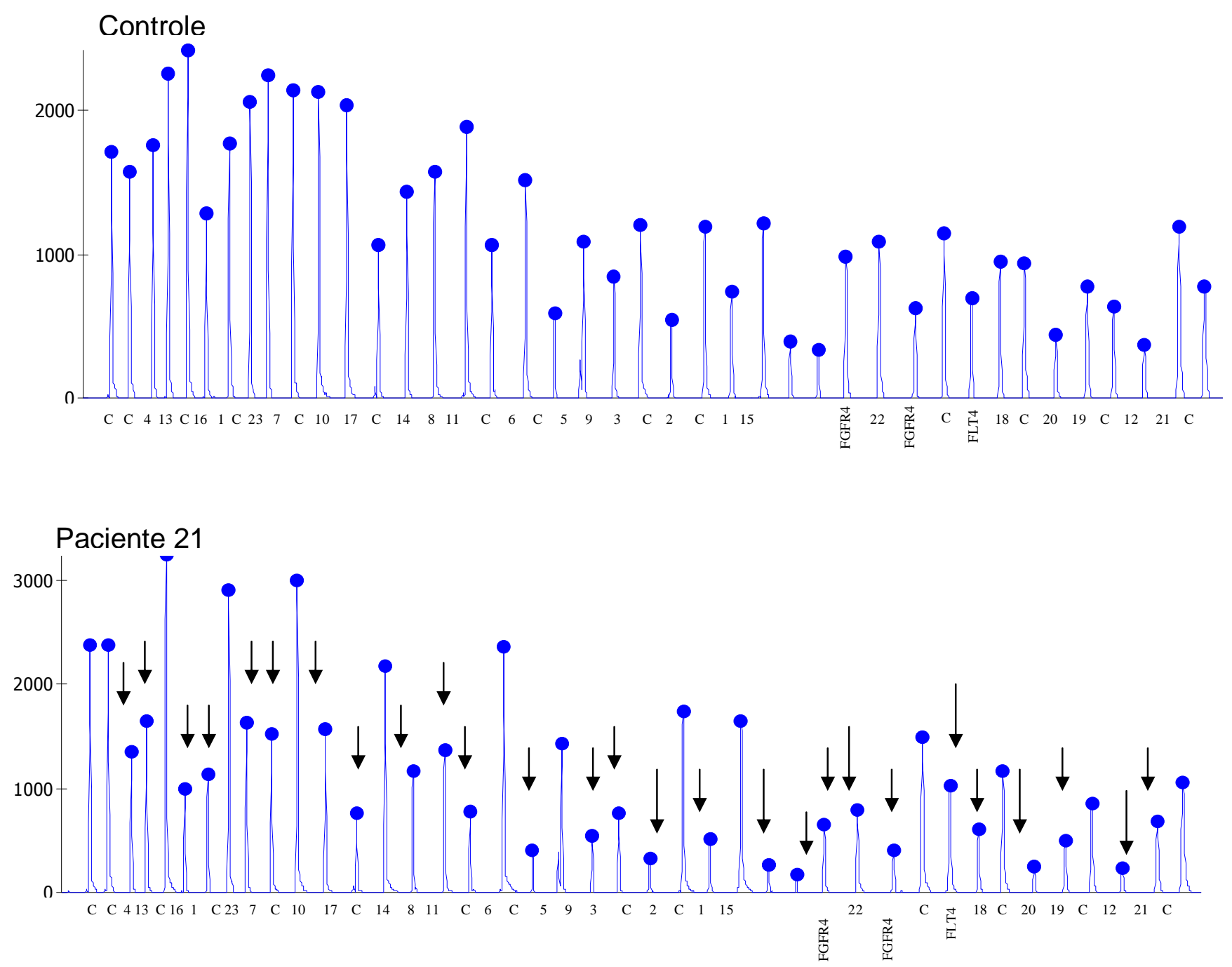

Figura 14: Deleção do gene NSD1 e FGFR4. As setas indicam a deleção. 
O paciente 2 apresentou deleção parcial do gene NSD1, com os exons 1, 2, $3,4,5,6,7,8,9,10,11,12,13,14,15,16$ e 17, além do gene FGFR4 deletados (figura 15).
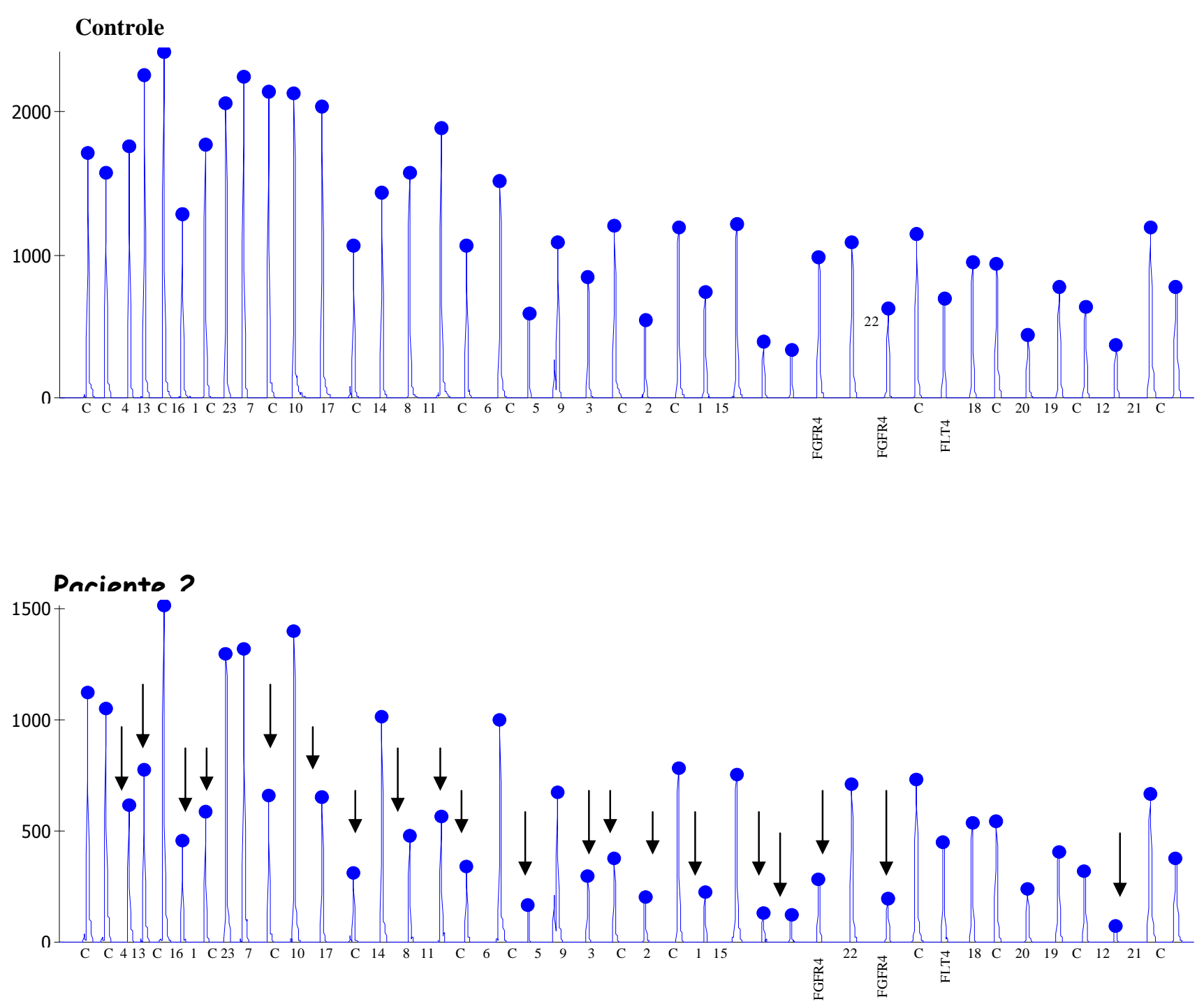

Figura 15: Deleção parcial do gene NSD1 e deleção do gene FGFR4. As setas indicam a deleção. 
No paciente 50 foi observado uma deleção parcial do gene NSD1, com apenas os exons 13 e 14 deletados (figura 16).
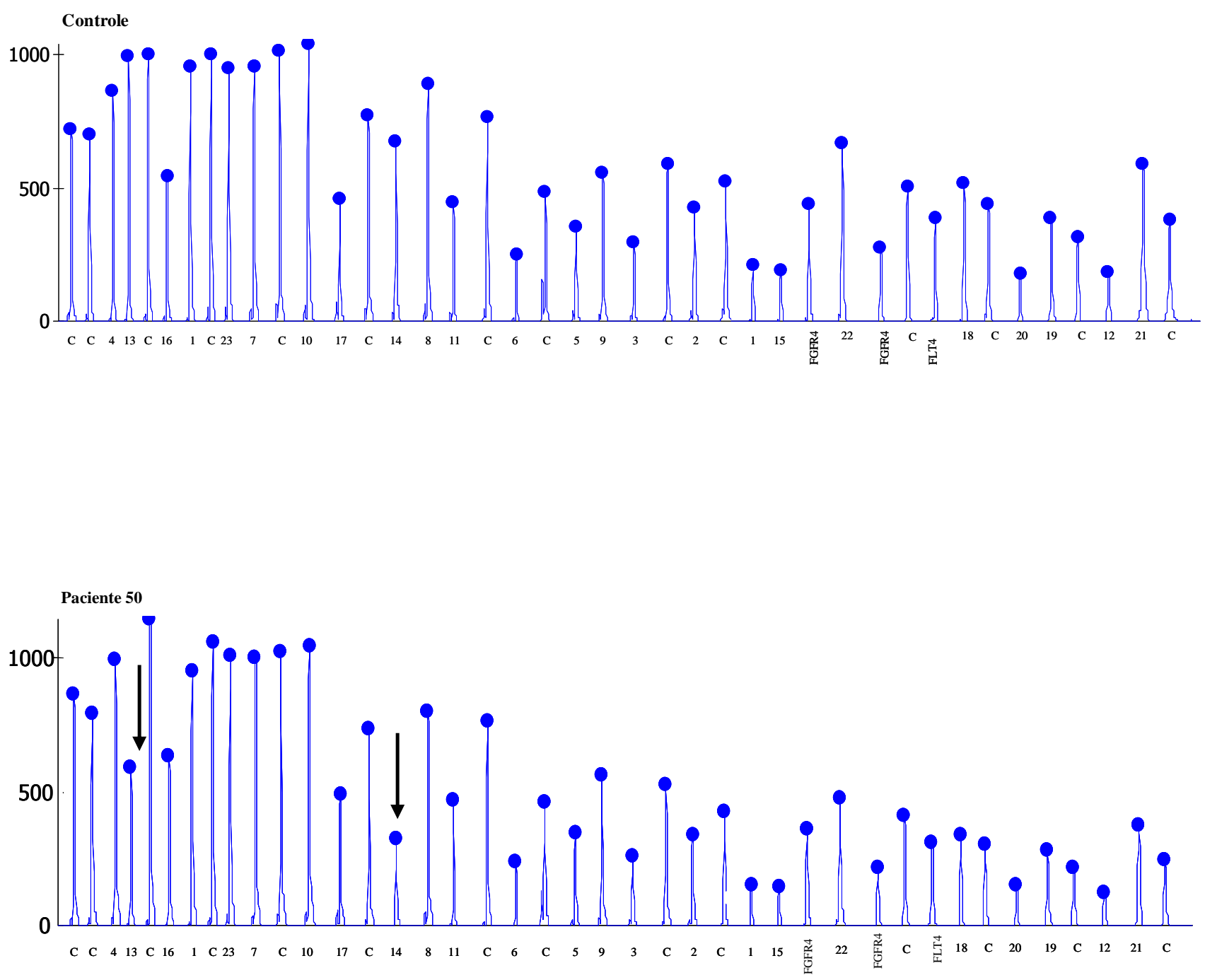

Figura 16: Deleção dos exons 13 e 14 do gene NSD1. As setas indicam a Deleção. 


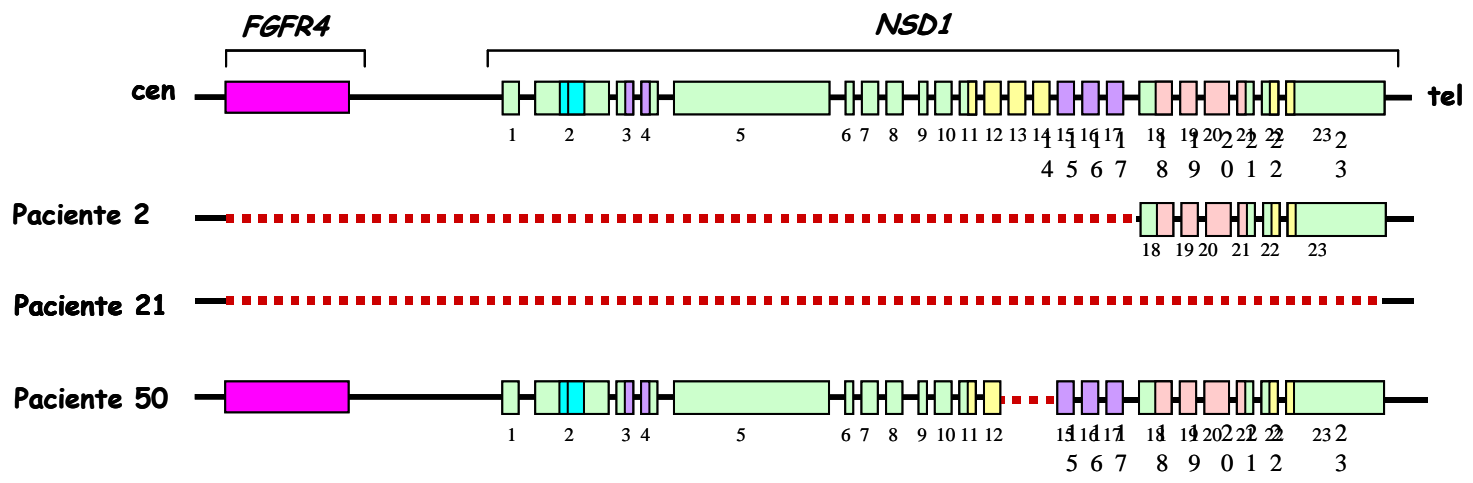

deleção

Figura 17: Representação esquemática das deleções de NSD1

Esses pacientes apresentam a face típica com abaulamento frontal, o queixo proeminente, a implantação frontal do cabelo alta; a macrocefalia, a dolicocefalia, as mãos grandes; hipotonia neonatal e icterícia também estão presentes nos três pacientes. Porém, os três pacientes nasceram com 0 comprimento e o peso dentro dos padrões de normalidade e não acima do percentil 97 como descrito para a Sos.

A altura e o peso atuais dos pacientes 2 e 50 está acima do percentil 97 . Já o paciente 21 apresenta altura no percentil 97 e o peso entre os percentis 75 e 50 $(75>p>50)$.

"Déficit" de coordenação motora, atraso na linguagem e dificuldade de aprendizagem foram observados nos pacientes 21 e 50 . A idade do paciente 2 ainda não permitiu a verificação dessas características (8 meses). 
Os pacientes 21 e 50 também apresentaram problemas de comportamento, como hiperatividade, agressividade e ansiedade. $\mathrm{O}$ paciente 2 pela idade ainda não manifestou essas características.

Anomalias cardiovasculares estão presentes nos pacientes 2 e 21 . Outras características estão relacionadas na tabela 1 (página 64). A figura 18 (página 65) mostra fotos dos três pacientes.

\section{IV.2 - Análise molecular para identificação de mutacões}

\section{IV.2.1 - Sequenciamento direto}

O gene NSD1 contém 23 exons, sendo que o exon 1 não é codificador. Apesar não haver "hotspots" para mutação neste gene, observamos que existe uma maior freqüência de mutações no exon 5 (tabela 2 - páginas 66), que é também o maior exon do gene com 2560 bp. Para a confecção da tabela 2, compilamos as mutações descritas na literatura (Douglas, et al, 2003; Faravelli, 2005; Kamikura, et al, 2003; Turkmen, et al, 2003).

Escolhemos, então, começar a sequenciar pelo exon 5 , que é analisado por meio de 11 pares de "primers" (tabela 3). 
Tabela 3: "Primers" para sequenciamento do exon 5 do gene NSD1

\begin{tabular}{|c|c|c|c|}
\hline Exon & Forward & Reverse & $\begin{array}{l}\text { Tamanho } \\
\text { (pb) }\end{array}$ \\
\hline $5 \mathrm{~A}$ & TCTGATTTCATCTCССТTTTCC & GGCTTTTCCTTCTCATCTGC & 315 \\
\hline $5 B$ & ATGCCATTTGAAGACTGCAC & TCCACAGGAAGAAAACAGAAAA & 360 \\
\hline $5 \mathrm{C}$ & TCCACAGGAAGAAAACAGAAAA & TATGGGATCCAGGTCACTGC & 323 \\
\hline $5 \mathrm{D}$ & GGAAAAGCGAAGTGATTCCA & TCTGACTGGGGTTTGTGAAC & 348 \\
\hline $5 \mathrm{E}$ & GGGTTGTACTAAGAGTGCAGAGC & TTAGAAATGCTGGCCAAAGG & 348 \\
\hline $5 F$ & TATGGCAGAACCCCCAGTTA & CGCTGCTCCTTCGTCTTACT & 381 \\
\hline $5 G$ & TGGAACATCAAAGCCATCAA & CGCCAGATAATGCAGAGTCA & 332 \\
\hline $5 \mathrm{H}$ & GGCTCCACACACAATTCAGA & CTCCCTGCAGTACAGCATCA & 334 \\
\hline 51 & ATGCTTTTTCAGCCCAAATG & CTGGGCCTTTTCCGTTTT & 312 \\
\hline $5 \mathrm{~J}$ & GATGTGCATTTCGATAGCAAG & GCTCTGTCAGTGGTTCCTCA & 343 \\
\hline $5 K$ & GGTCTTACTTCCTAGTGACC & TATCACATTTAGATGTCCTTAC & 255 \\
\hline
\end{tabular}

Dos 65 pacientes da amostra, 30 pacientes foram selecionados para 0 sequenciamento do gene NSD1 por apresentarem características típicas da síndrome de Sotos, principalmente a face típica (gestalt).

Com o primer $5 \mathrm{~A}$, os 30 pacientes foram seqüenciados. Nesse fragmento do exon 5 não observamos alterações.

Com o primer 5B, foram seqüenciados 30 pacientes. Em nove foi encontrada uma alteração em heterozigose, com uma substituição de uma citosina 
por uma timina $(C>T)$ (figura 19). Nesta amostra a freqüência deste SNP é de 0,3 .

A

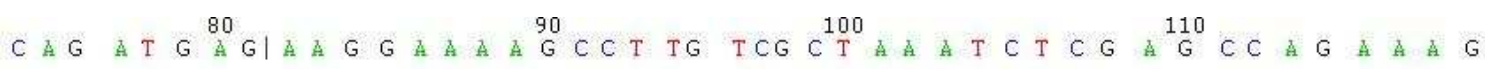

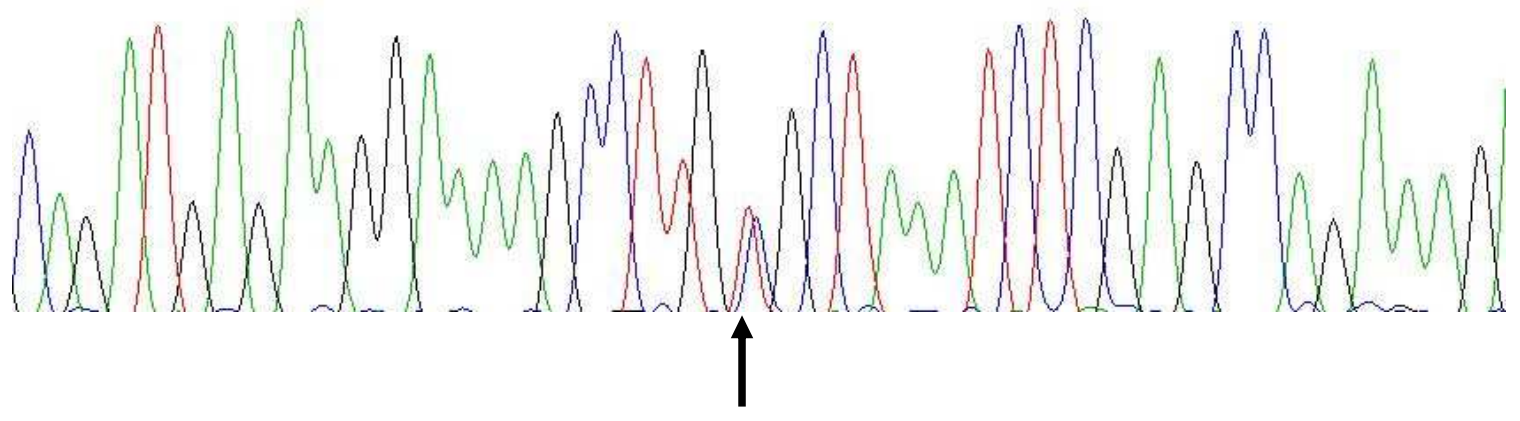

\section{B}

ATGCCATTTGAAGACTGCACaatgatcctgagtcagaacatgacctgtt gcttaatggctgtttgaatcactggctttgattctgaacattctgcagatgagaagg aaagccttgcgctaatctcgagccagaagagctctgataatccaaaa $\uparrow$

Figura 19: A. Eletroferograma representando a heterozigose c/t. A seta mostra a alteração. B. Seqüência referencia do fragmento do exon 5 (primer 5B). Em azul, o primer 5B foward. Em amarelo, a seqüência representada no cromatograma. Em vermelho o alelo selvagem c. 
Nesta amostra, com uma freqüência de 0,06 (2/30) também foi observado esse polimorfismo em homozigose (Figura 20).

A $\underset{A}{70} G$ A T G A G A A G G G A A A A G C C T T T \begin{tabular}{l}
90 \\
\hline
\end{tabular}

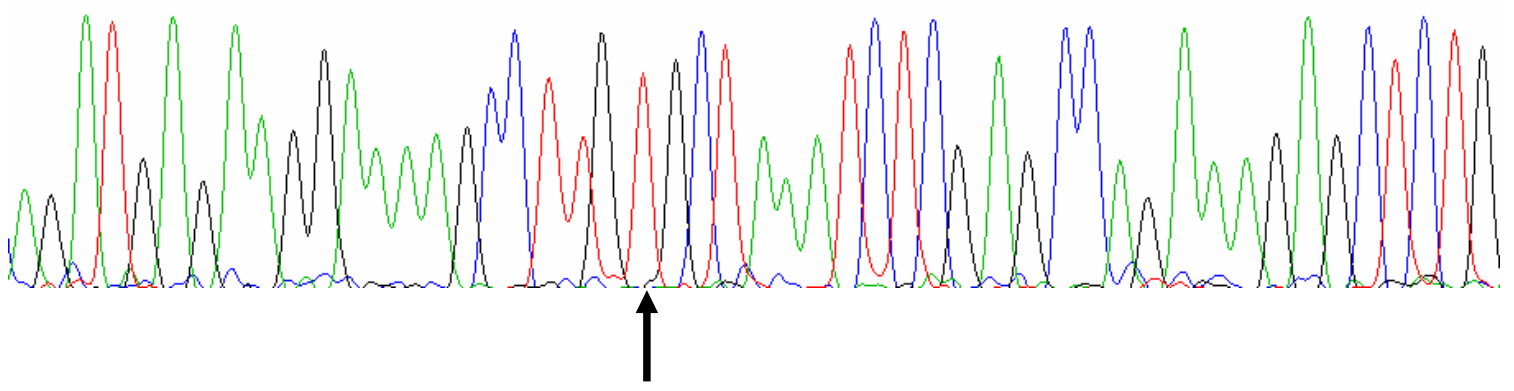

B

ATGCCATTTGAAGACTGCACaatgatcctgagtcagaacatgacctgtt gcttaatggctgtttgaa a cactggctttgattctgaacattctgcagatgagaagg aaagccttgtgctaatctcgagccagaagagctctgataatccaaaa $\uparrow$

Figura 20: A. Eletroferograma representando o polimorfismo homozigoto t/t. A seta mostra a alteração. B. Seqüência referencia do fragmento do exon 5 (primer 5B). Em azul, o primer 5B foward. Em amarelo, a seqüência representada no cromatograma. Em vermelho o alelo selvagem C. 
Com o primer 5D, os 30 pacientes foram seqüenciados e foi observado outro polimorfismo (SNP) com uma substituição de uma citosina por uma timina (C $>\mathrm{T}$ ) em sete pacientes (figura 21). Nesta amostra a freqüência deste SNP é de 0,23 .

A
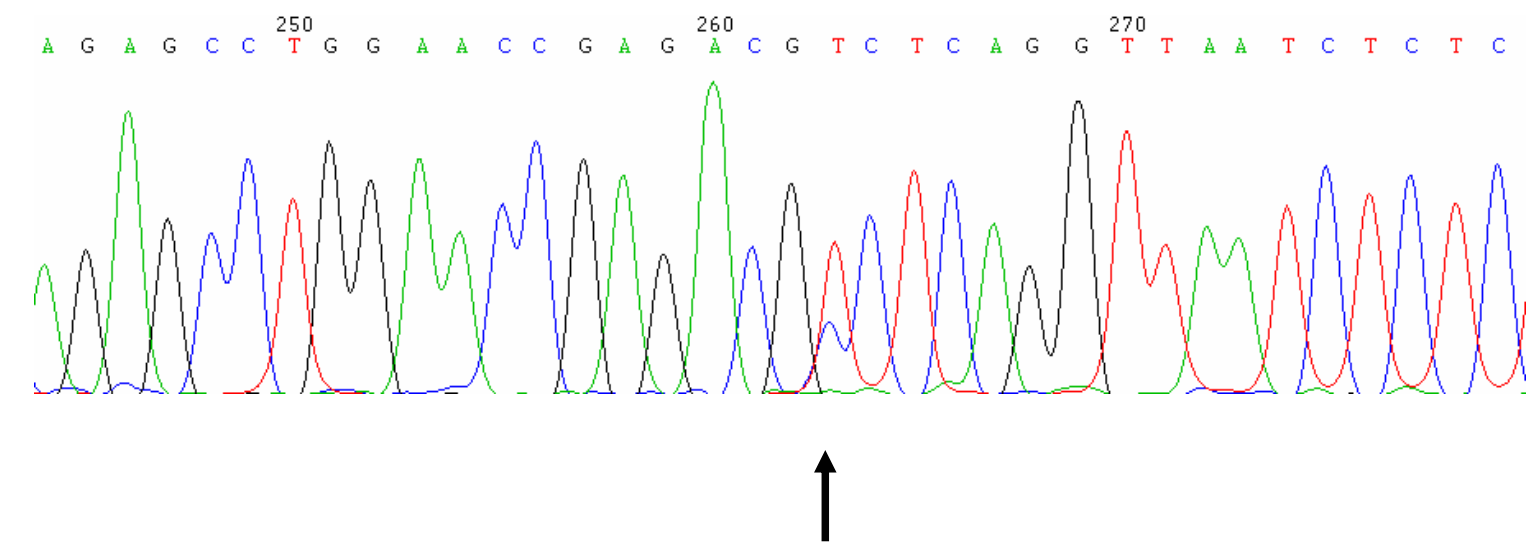

B

agggtaaagcaaacagaagcctctcattagtaactcacatacagacc acttaatgggttgtactaagagtgcagagcctggaaccgagacgtctcag gttaatctctctgatctg

Figura 21: A. Eletroferograma representando o polimorfismo heterozigoto $t / c$. A seta mostra a alteração. B. Seqüência referencia do fragmento do exon 5 (primer 5B). Em amarelo, a seqüência representada no cromatograma. Em vermelho o alelo selvagem $\mathrm{t}$. 
Os trinta pacientes também foram seqüenciados com o primer $5 \mathrm{E}$. Nesses não foram encontradas alterações.

\section{IV.3 - Achados Clínicos dos pacientes}

A casuística conta com 65 pacientes com suspeita de diagnóstico clínico da Síndrome de Sotos.

As principais características clínicas dos 30 pacientes selecionados pelas suas características típicas ("fácies típica” e macrocefalia) estão relacionadas na tabela 4 (página 70).

A idade dos 30 pacientes varia de 1 ano até 14 anos e 6 meses. A idade materna varia de 16 a 36 anos e a paterna de 20 a 45 anos.

O comprimento ao nascer acima do percentil 97 está presente em 5/24 $(20,8 \%)$ dos pacientes. A altura acima do percentil 97 foi observado em 22/30 (73,3\%) dos pacientes e o peso, acima do percentil 97 , em 20/29 (68,9\%) dos pacientes.

A macrocefalia está presente em 29/30 (96,6\%) dos pacientes, mas a macrocefalia ao nascer foi observado em apenas $8 / 18(44,4 \%)$. A dolicocefalia foi observado em 16/27 (59,2\%) dos pacientes.

As características da face típica são: abaulamento frontal, que aparece em 25/29 (86,2\%); prognatismo, observado em 12/29 (41,3\%); queixo proeminente presente em 25/30 (83,3\%); hipertelorismo, observado em 22/29 (76,8\%); fissura 
palpebral antimongolóide está presente em 16/29 (55,1\%); estrabismo em 13/28 $(46,4 \%)$; implantação alta de cabelo na fronte foi observado em 25/28 (89,2\%).

As orelhas grandes, acima do percentil 97 , estão presentes em 12/28 $(43,8 \%)$.

Em 17/22 (77,2\%) dos pacientes a idade óssea está avançada. A articulação frouxa foi observada em 8/22 (36,3\%) e genu valgo em 7/22 (31,8\%) dos pacientes.

Mãos grandes, acima do percentil 97, foram observadas em 19/29 (65,5\%) e sindactilia nas mãos está presente em 3/27 (11,1\%). Já os pés grandes ( $p>97)$ estão presentes em 14/28 (50\%), a sindactilia nos pés foi observada em 13/27 $(48,1 \%)$ e o pé plano em $7 / 27(25,9 \%)$ dos pacientes. As unhas quebradiças, tanto das mãos quanto dos pés foram observadas em 10/27 (37\%).

O "déficit" de coordenação motora está presente em 19/25 (76\%). A dificuldade da linguagem foi observada em 26/30 (86,6\%), a dificuldade de aprendizagem em 18/23 (78,2\%) e a hipotonia neonatal está presente em 16/25 (64\%) dos pacientes.

Convulsões foram observadas em 9/28 (32,1\%) dos pacientes, destes aproximadamente $55 \%$ acompanhadas por febres. Anomalias cerebrais, como ventriculomegalia, foram observadas em 14/24 (58,3\%) dos pacientes.

Foi observado dificuldade de alimentação em 4/28 (14,3\%), sialorréia em 9/28 (32,1\%), icterícia em $16 / 30(53,3 \%)$ e otite recorrente em $7 / 28$ (25\%) dos pacientes.

Distúrbios comportamentais estão presentes em todos os pacientes: mau humor (8/28 - 28,5\%), agressividade (13/28 - 46,4\%), hiperatividade (11/27 - 
$40,7 \%)$, ansiedade $(18 / 27-66,6 \%)$ e comportamento anti-social $(10 / 29-34,4 \%)$. A figura 22 (página 78) apresenta as fotos dos pacientes estudados evidenciando algumas das características clínicas da síndrome de Sotos.

As características clínicas e comportamentais observadas nos pacientes considerados não típicos estão descritos na tabela 7 no anexo VIII.4. 
Tabela 1: Características Fenotípicas dos Pacientes com Deleção

\begin{tabular}{|c|c|c|c|}
\hline \multirow[t]{2}{*}{ Características clínicas } & \multicolumn{3}{|c|}{ Pacientes com deleções } \\
\hline & 2 & 21 & 50 \\
\hline Idade & $8 m$ & $5 a$ & $7 a$ \\
\hline Idade Materna & $25 a$ & $20 a$ & $32 a$ \\
\hline Idade Paterna & $23 a$ & $27 a$ & $42 a$ \\
\hline Comprimento ao nascer $p>97$ & $p=90$ & $10>p>3$ & $75>p>50$ \\
\hline Altura atual p>97 & p>97 & $p=97$ & $\mathrm{p}>97$ \\
\hline Peso ao nascer $p>97$ & $10>p>3$ & $25>p>50$ & $\mathrm{p}<2,5$ \\
\hline Peso atual $p>97$ & $p>97$ & $75>p>50$ & $p>97$ \\
\hline Macrocefalia & S & S & S \\
\hline Macrocefalia ao nascer & $S$ & $?$ & $?$ \\
\hline Dolicocefalia & S & S & S \\
\hline Abaulamento frontal & $\mathrm{S}$ & $\mathrm{S}$ & $\mathrm{N}$ \\
\hline Queixo proeminente & $\mathrm{S}$ & $S$ & $\mathrm{~N}$ \\
\hline Hipertelorismo & $\mathrm{S}$ & $\mathrm{S}$ & $\mathrm{N}$ \\
\hline Fissura palpebral antimongolóide & $\mathrm{S}$ & $S$ & $\mathrm{~N}$ \\
\hline Estrabismo & $\mathrm{N}$ & $\mathrm{S}$ & $\mathrm{S}$ \\
\hline Orelhas grandes & $S$ & $\mathrm{~N}$ & $\mathrm{~N}$ \\
\hline $\begin{array}{l}\text { Implantação frontal do cabelo } \\
\text { alta }\end{array}$ & S & $\mathrm{S}$ & $\mathrm{S}$ \\
\hline Idade óssea avançada & $?$ & $\mathrm{~N}$ & $\mathrm{~S}$ \\
\hline Articulação frouxa & $?$ & $\mathrm{~N}$ & S \\
\hline Genu valgus & $?$ & $\mathrm{~N}$ & $?$ \\
\hline Mãos grandes (p>97) & S & S & S \\
\hline Pés grandes ( $p>97)$ & $\mathrm{N}$ & $\mathrm{N}$ & $S$ \\
\hline Pé plano & $S$ & $\mathrm{~S}$ & $\mathrm{~N}$ \\
\hline Sindactilia nos pés & $S$ & $\mathrm{~N}$ & $S$ \\
\hline Unhas quebradiças e finas & $?$ & $\mathrm{~N}$ & $\mathrm{~N}$ \\
\hline Idade que sentou & $8 m$ & $10 \mathrm{~m}$ & $8 m$ \\
\hline Idade que andou & & $2 a$ & $2 \mathrm{a} 1 \mathrm{~m}$ \\
\hline Defict de coordenação motora & $?$ & $S$ & S \\
\hline Hipotonia neonatal & $\mathrm{S}$ & S & S \\
\hline Atraso da linguagem & & $\mathrm{S}$ & $S$ \\
\hline Dificuldade de aprendizagem & & $\mathrm{S}$ & S \\
\hline $\begin{array}{c}\text { Dificuldade de alimentação ao } \\
\text { nascer }\end{array}$ & S & $\mathrm{N}$ & S \\
\hline Sialorréia & $\mathrm{N}$ & S & $\mathrm{N}$ \\
\hline Icterícia & $\mathrm{S}$ & $S$ & $\mathrm{~S}$ \\
\hline Otite & $\mathrm{N}$ & $S$ & $\mathrm{~N}$ \\
\hline Mau humor & & $\mathrm{N}$ & $\mathrm{S}$ \\
\hline Agressividade & & $\mathrm{S}$ & $S$ \\
\hline Hiperatividade & & S & $\mathrm{S}$ \\
\hline Ansiedade & & $S$ & $\mathrm{~S}$ \\
\hline Comportamento anti-social & & $\mathrm{N}$ & $S$ \\
\hline Outros & $\begin{array}{c}\text { Anomalias } \\
\text { cardiovasculares, } \\
\text { Hipoglicemia ao } \\
\text { nascer }\end{array}$ & $\begin{array}{c}\text { Anomalias } \\
\text { cardiovasculares }\end{array}$ & $\begin{array}{l}\text { Braços longos, } \\
\text { Nistagmo, palato } \\
\text { alto e estreito }\end{array}$ \\
\hline
\end{tabular}


Figura 18: Fotos dos pacientes com deleções

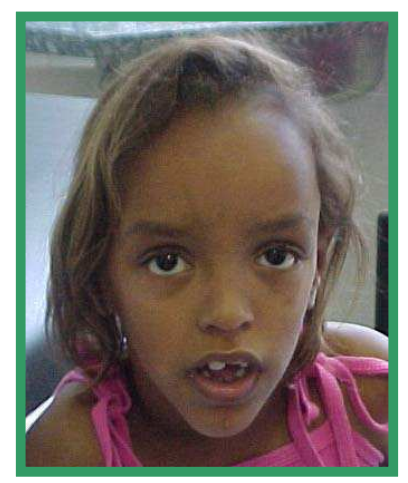

Deleção Total do gene NSD1, incluíndo o gene FGFR4

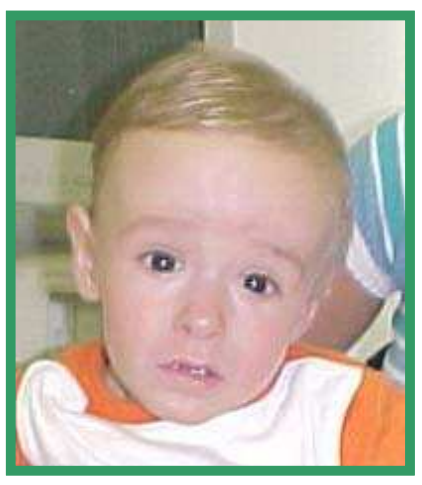

Deleção parcial: gene FGFR4 até exon 17 do gene NSD1

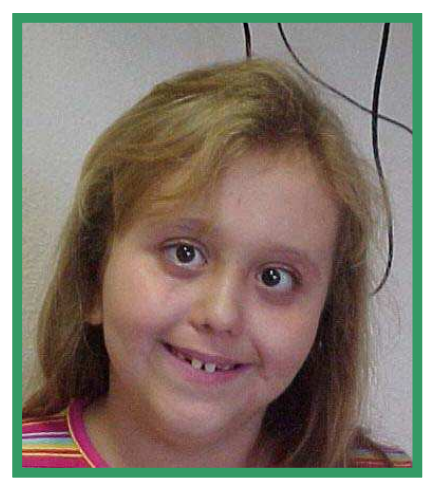

Deleção parcial: exons 13 e 14 
Tabela 2: Mutações intragênicas e exônicas no gene NSD1

\begin{tabular}{|c|c|c|}
\hline Exon & Mutação & Tipo mutação \\
\hline 2 & 896delC & Deleção \\
\hline 4 & 1171delC & deleção \\
\hline 4 & $1130 \mathrm{G}>\mathrm{A}$ & Nonsense \\
\hline 5 & 1727delA & deleção \\
\hline 5 & 2576delAT & deleção \\
\hline 5 & 3383delCT & deleção \\
\hline 5 & 2807-8insA & inserção \\
\hline 5 & 3549-50insT & inserção \\
\hline 5 & $1492 \mathrm{C}>\mathrm{T}$ & Nonsense \\
\hline 5 & $1810 \mathrm{C}>\mathrm{T}$ & Nonsense \\
\hline 5 & $2323 C>T$ & Nonsense \\
\hline 5 & 1807delT & deleção \\
\hline 5 & 2053-2057del & Deleção \\
\hline 5 & 2363delG & Deleção \\
\hline 5 & 2386delGAAA & Deleção \\
\hline 5 & 2432delG & Deleção \\
\hline 5 & 2760delTAGG & Deleção \\
\hline 5 & 3141delC & Deleção \\
\hline 5 & 3160delA & Deleção \\
\hline 5 & 3197delC & Deleção \\
\hline 5 & 3273delT & Deleção \\
\hline 5 & $3355 \mathrm{delC}$ & Deleção \\
\hline 5 & 3536delA & Deleção \\
\hline 5 & 3541delGAAA & Deleção \\
\hline 5 & 3708delTTGT & Deleção \\
\hline 5 & $1310 C>G$ & Nonsense \\
\hline 5 & $1318 \mathrm{C}>\mathrm{T}$ & Nonsense \\
\hline 5 & $1828 \mathrm{C}>\mathrm{T}$ & Nonsense \\
\hline 5 & $3063 T>A$ & Nonsense \\
\hline 5 & $3091 \mathrm{C}>\mathrm{T}$ & Nonsense \\
\hline 5 & $3214 \mathrm{C}>\mathrm{T}$ & Nonsense \\
\hline 5 & 2362delG & Deleccão \\
\hline 5 & 3196delC & Deleção \\
\hline 5 & 3316-7insT & inserção \\
\hline 5 & 3705-8delTTGT & Deleção \\
\hline 5 & $2362 \mathrm{C}>\mathrm{T}$ & Nonsense \\
\hline 5 & $3067 \mathrm{C}>\mathrm{T}$ & Nonsense \\
\hline 5 & $3071 C>G$ & Nonsense \\
\hline 5 & 1283delC & Deleção \\
\hline 5 & 2011delA & Deleção \\
\hline 5 & 2100_2101delGA & Deleção \\
\hline 5 & 2603_2604delCT & Deleção \\
\hline 5 & 2852delG & Deleção \\
\hline 5 & 2954 2955delCT & Deleccão \\
\hline 5 & 32̄84delG & Deleção \\
\hline 5 & 1456dupT & Duplicação \\
\hline
\end{tabular}


Tabela 2: Mutações intragênicas e exônicas no gene NSD1

\begin{tabular}{|c|c|c|}
\hline rav." & 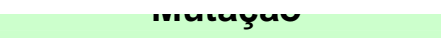 & 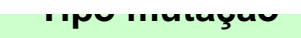 \\
\hline 5 & 2239dupA & Duplicação \\
\hline 5 & 2602dupT & Duplicação \\
\hline 5 & 3125dupC & Duplicação \\
\hline 5 & 3442dupC & Duplicação \\
\hline 5 & 3597dupG & Duplicação \\
\hline 5 & $1845 \mathrm{~T}>\mathrm{A}$ & Nonsense \\
\hline 5 & $2654 C>G$ & Nonsense \\
\hline 5 & $3290 T>A$ & Nonsense \\
\hline 5 & $3439 G>T$ & Nonsense \\
\hline 5 & 3530_3535delTTAAAG & Deleção \\
\hline 5 & $3661 \mathrm{C}>\mathrm{T}$ & Nonsense \\
\hline 5 & $3775 \mathrm{C}>\mathrm{T}$ & Nonsense \\
\hline 5 & $3062 T>A$ & Missense \\
\hline 5 & $3090 \mathrm{C}>\mathrm{T}$ & Missense \\
\hline 5 & $1262 \mathrm{G}>\mathrm{A}$ & Nonsense \\
\hline 5 & 2167-2168insA & inserção \\
\hline 5 & 3146-3147insA & inserção \\
\hline 5 & 1456delT & Deleção \\
\hline 5 & 3578 3582delGTGAC & Deleção \\
\hline 6 & 3841delC & Deleção \\
\hline 6 & 3844delTTGGAinsGATC & Deleção/inserção \\
\hline 6 & $3886 \mathrm{~A}>\mathrm{T}$ & Nonsense \\
\hline 7 & 4139delAAGTinsCTG & Deleção/inserção \\
\hline 7 & $3958 \mathrm{C}>\mathrm{T}$ & Nonsense \\
\hline 7 & $3964 \mathrm{C}>\mathrm{T}$ & Nonsense \\
\hline 7 & 4160insC & Inserção \\
\hline 7 & $4138 \mathrm{G}>\mathrm{T}$ & Nonsense \\
\hline 7 & $4057 \mathrm{G}>\mathrm{T}$ & Nonsense \\
\hline 9 & 4308_4311dupTGAA & Duplicação \\
\hline 10 & $4411 \mathrm{C}>\mathrm{T}$ & Nonsense \\
\hline 10 & $4417 \mathrm{C}>\mathrm{T}$ & Nonsense \\
\hline 10 & 4390delATATins8 & Deleção/inserção \\
\hline 10 & $4411 \mathrm{C}>\mathrm{G}$ & Missense \\
\hline 10 & 4479_4488dup & Duplicação \\
\hline 12 & $4731-2$ delAA & Deleção \\
\hline 13 & 4883delT & deleção \\
\hline 13 & $4847 \mathrm{~A}>\mathrm{T}$ & Missense \\
\hline 13 & $4910 T>C$ & Missense \\
\hline 13 & 4806delTGTTAAA & Deleção \\
\hline 13 & $4895 \mathrm{delG}$ & Deleção \\
\hline 13 & $4885 \mathrm{C}>\mathrm{T}$ & Nonsense \\
\hline 13 & 4769insT & Inserção \\
\hline 13 & $4818 C>A$ & Nonsense \\
\hline 13 & $4786 \mathrm{~T}>\mathrm{C}$ & Missense \\
\hline 14 & 5008-9insG & inserção \\
\hline 14 & $5022 C>G$ & Missense \\
\hline 14 & $5060 T>A$ & Missense \\
\hline
\end{tabular}


Tabela 2: Mutações intragênicas e exônicas no gene NSD1

\begin{tabular}{|c|c|c|}
\hline Exon & Mutação & Tipo mutação \\
\hline 14 & $4987 C>T$ & Missense \\
\hline 14 & 5020delT & Deleção \\
\hline 14 & $5098 \mathrm{C}>\mathrm{T}$ & Nonsense \\
\hline 14 & $5069 \mathrm{C}>\mathrm{T}$ & Missense \\
\hline 14 & $5737 \mathrm{~T}>\mathrm{G}$ & Missense \\
\hline 14 & $5059 \mathrm{~T}>\mathrm{A}$ & Missense \\
\hline 15 & $5194 G>T$ & Nonsense \\
\hline 15 & $5229 G>A$ & Nonsense \\
\hline 15 & $5178 \mathrm{~T}>\mathrm{C}$ & Missense \\
\hline 15 & $5179 G>C$ & Missense \\
\hline 15 & $5296 \mathrm{C}>\mathrm{T}$ & Nonsense \\
\hline 15 & $5198 \mathrm{G}>\mathrm{C}$ & Missense \\
\hline 15 & $5201 \mathrm{~T}>\mathrm{C}$ & Missense \\
\hline 16 & $5332 \mathrm{C}>\mathrm{T}$ & Nonsense \\
\hline 16 & $5375 \mathrm{G}>\mathrm{T}$ & Missense \\
\hline 16 & $5341 \mathrm{delC}$ & Deleção \\
\hline 16 & $5431 \mathrm{C}>\mathrm{T}$ & Nonsense \\
\hline 16 & 5398ins T & Inserção \\
\hline 16 & $5386 G>T$ & Missense \\
\hline 16 & $5414 \mathrm{~T}>\mathrm{A}$ & Nonsense \\
\hline 16 & $5431 \mathrm{C}>\mathrm{T}$ & Missense \\
\hline 17 & $5611 \mathrm{~A}>\mathrm{T}$ & Nonsense \\
\hline 17 & $5566 \mathrm{C}>\mathrm{T}$ & Nonsense \\
\hline 17 & $5581 \mathrm{C}>\mathrm{T}$ & Nonsense \\
\hline 17 & $5513 T>C$ & Missense \\
\hline 17 & 5615delTA & Deleção \\
\hline 18 & 5744-5insT & inserção \\
\hline 18 & $5861 \mathrm{G}>\mathrm{A}$ & Nonsense \\
\hline 18 & $5773 \mathrm{~T}>\mathrm{C}$ & Missense \\
\hline 18 & $5684 G>A$ & Missense \\
\hline 18 & $5864 G>A$ & Missence \\
\hline 18 & $5740 \mathrm{C}>\mathrm{T}$ & Missense \\
\hline 18 & $5854 \mathrm{C}>\mathrm{T}$ & Missense \\
\hline 18 & 5737delA & Deleção \\
\hline 18 & $5691 \mathrm{~T}>\mathrm{G}$ & Missense \\
\hline 18 & $5885 T>C$ & \\
\hline 19 & $6001 \mathrm{delC}$ & deleção \\
\hline 19 & 5998insT & Inserção \\
\hline 19 & $5951 \mathrm{G}>\mathrm{A}$ & Missense \\
\hline 19 & $5990 A>G$ & Missense \\
\hline 19 & $5950 \mathrm{C}>\mathrm{T}$ & Nonsense \\
\hline 19 & $5965 C>T$ & Nonsense \\
\hline 19 & 5927_5928delTA & Deleção \\
\hline 19 & 5938_5940delGAA & Deleção \\
\hline 19 & $5951 \mathrm{G}>\mathrm{A}$ & Missense \\
\hline 19 & $5989 A>G$ & Missense \\
\hline 19 & 5903delT & Deleção \\
\hline
\end{tabular}


Tabela 2: Mutações intragênicas e exônicas no gene NSD1

\begin{tabular}{|c|c|c|}
\hline Exon & Mutação & Tipo mutação \\
\hline 19 & 5911delT & Deleção \\
\hline 19 & 5989T>C & Missense \\
\hline 20 & $6014 \mathrm{G}>\mathrm{A}$ & Missense \\
\hline 20 & $6050 \mathrm{G}>\mathrm{A}$ & Missense \\
\hline 20 & $6013 C>T$ & Nonsense \\
\hline 20 & $6049 \mathrm{C}>\mathrm{T}$ & Missence \\
\hline 20 & $4642-2 A>T$ & Splice-site \\
\hline 20 & $6026 \mathrm{C}>\mathrm{T}$ & Missense \\
\hline 20 & $6062 A>G$ & Missense \\
\hline 20 & $6080 \mathrm{G}>\mathrm{A}$ & Missense \\
\hline 20 & $6095 \mathrm{G}>\mathrm{T}$ & Missense \\
\hline 20 & $6048 \mathrm{C}>\mathrm{T}$ & Missense \\
\hline 20 & $6059 A>G$ & \\
\hline 22 & 6302delA & Deleção \\
\hline 22 & $6431-2$ ins 17 & inserção \\
\hline 22 & $6450-1$ ins C & inserção \\
\hline 22 & $6429 \mathrm{C}>\mathrm{G}$ & Missense \\
\hline 22 & 6291-4delGAAA & Deleção \\
\hline 22 & 6311-2delAG & Deleção \\
\hline 22 & $6454 \mathrm{C}>\mathrm{T}$ & Nonsense \\
\hline 22 & 6363delT & Deleção \\
\hline 22 & 6290dupA & Duplicação \\
\hline 22 & 6383dupG & Duplicação \\
\hline 22 & 6403_6404insT & Inserção \\
\hline 22 & $62 \overline{8} 0 \mathrm{G}>\mathrm{T}$ & Nonsense \\
\hline 22 & 6291delG & Deleção \\
\hline 22 & $6356 A>G$ & \\
\hline 23 & $6548 \mathrm{G}>\mathrm{C}$ & Missense \\
\hline 23 & 6532delTGCCCCAGC & Deleção \\
\hline 23 & $6499 \mathrm{~T}>\mathrm{C}$ & Missense \\
\hline 23 & $6680 \mathrm{C}>\mathrm{T}$ & Missense \\
\hline 23 & $6559 \mathrm{C}>\mathrm{T}$ & Nonsense \\
\hline 23 & $6476 \mathrm{G}>\mathrm{A}$ & Missense \\
\hline 23 & 6521delTCT & Missense \\
\hline 23 & $6533 G>A$ & Missense \\
\hline 23 & $6472 \mathrm{G}>\mathrm{T}$ & Nonsense \\
\hline Int 8 & IVS8-2A>G & Splice-site \\
\hline Int 15 & IVS15-1G>C & Splice-site \\
\hline Int 15 & IVS15-1G>T & Splice-site \\
\hline Int 15 & IVS15+1G>C & Splice-site \\
\hline Int 16 & IVS16-2delA & Splice-site \\
\hline Int 18 & IVS18-2A>G & Splice-site \\
\hline Int 19 & IVS19-2A>G & Splice-site \\
\hline Int 20 & $6151+1 G>A$ & Splice-site \\
\hline \multirow[t]{3}{*}{ Int 21} & IVS21+1G>A & \\
\hline & $4641+1 G>A$ & Splice-site \\
\hline & $59-892+1 \mathrm{G}>\mathrm{T}$ & Splice-site \\
\hline
\end{tabular}




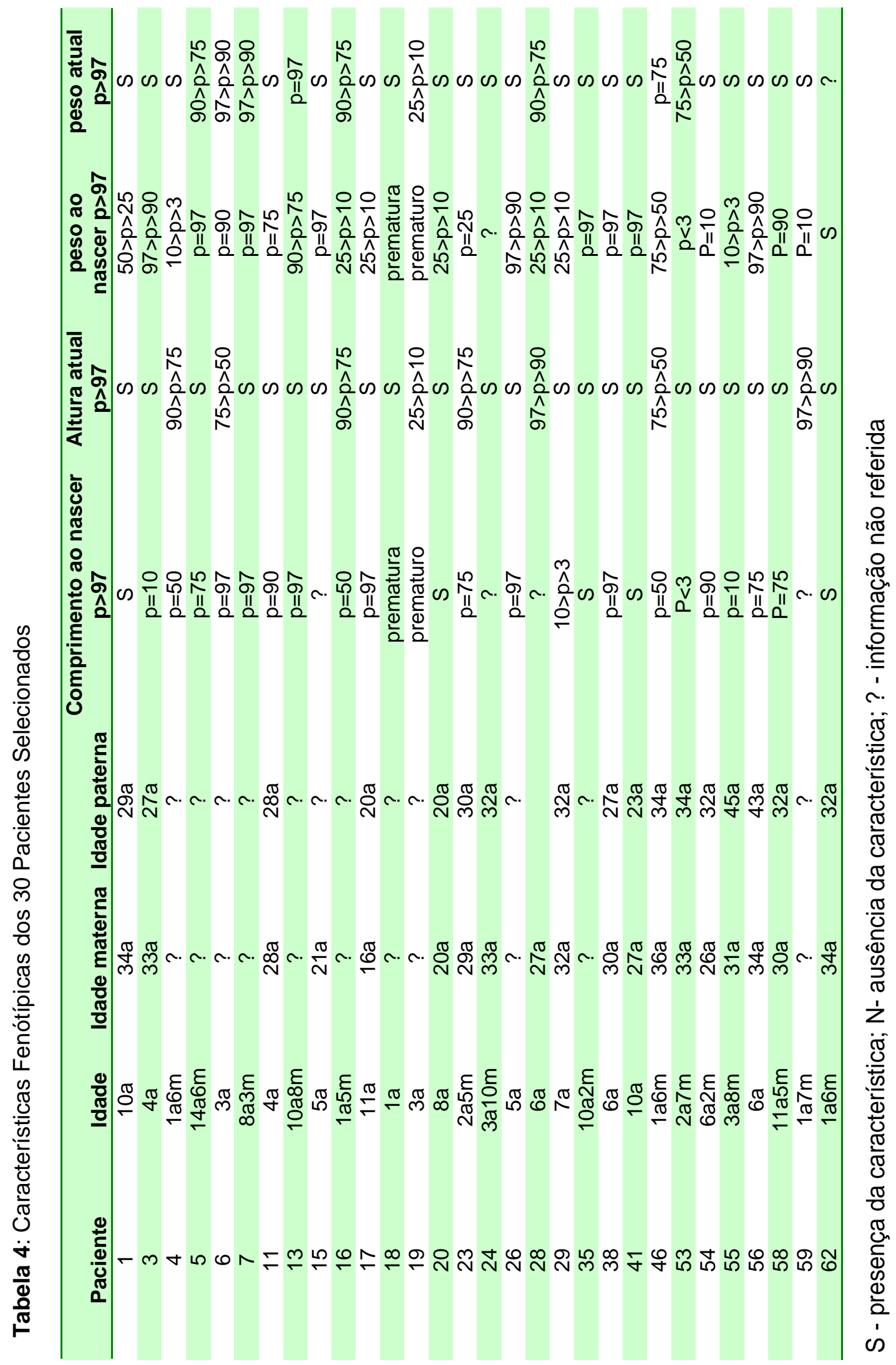




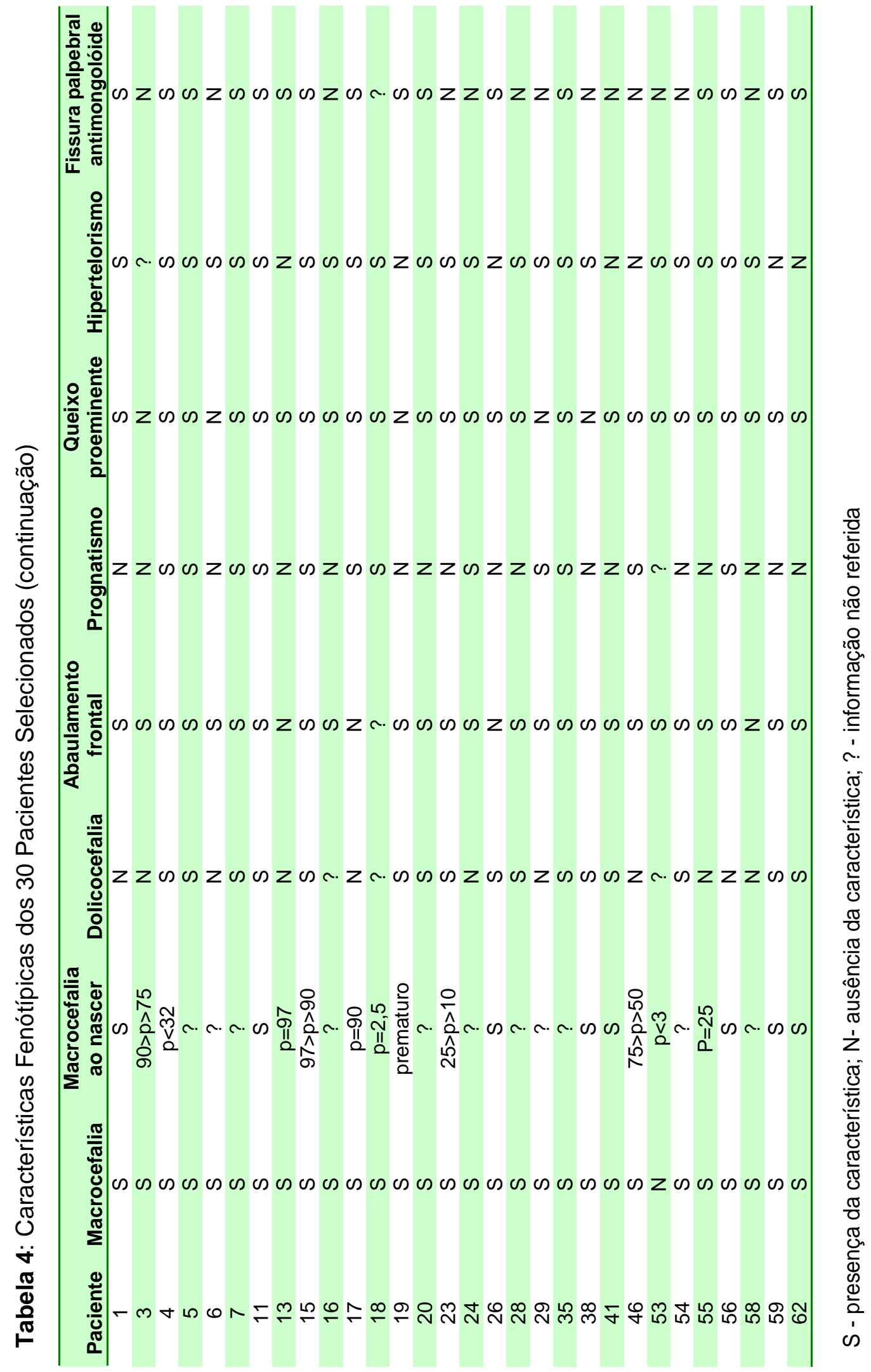




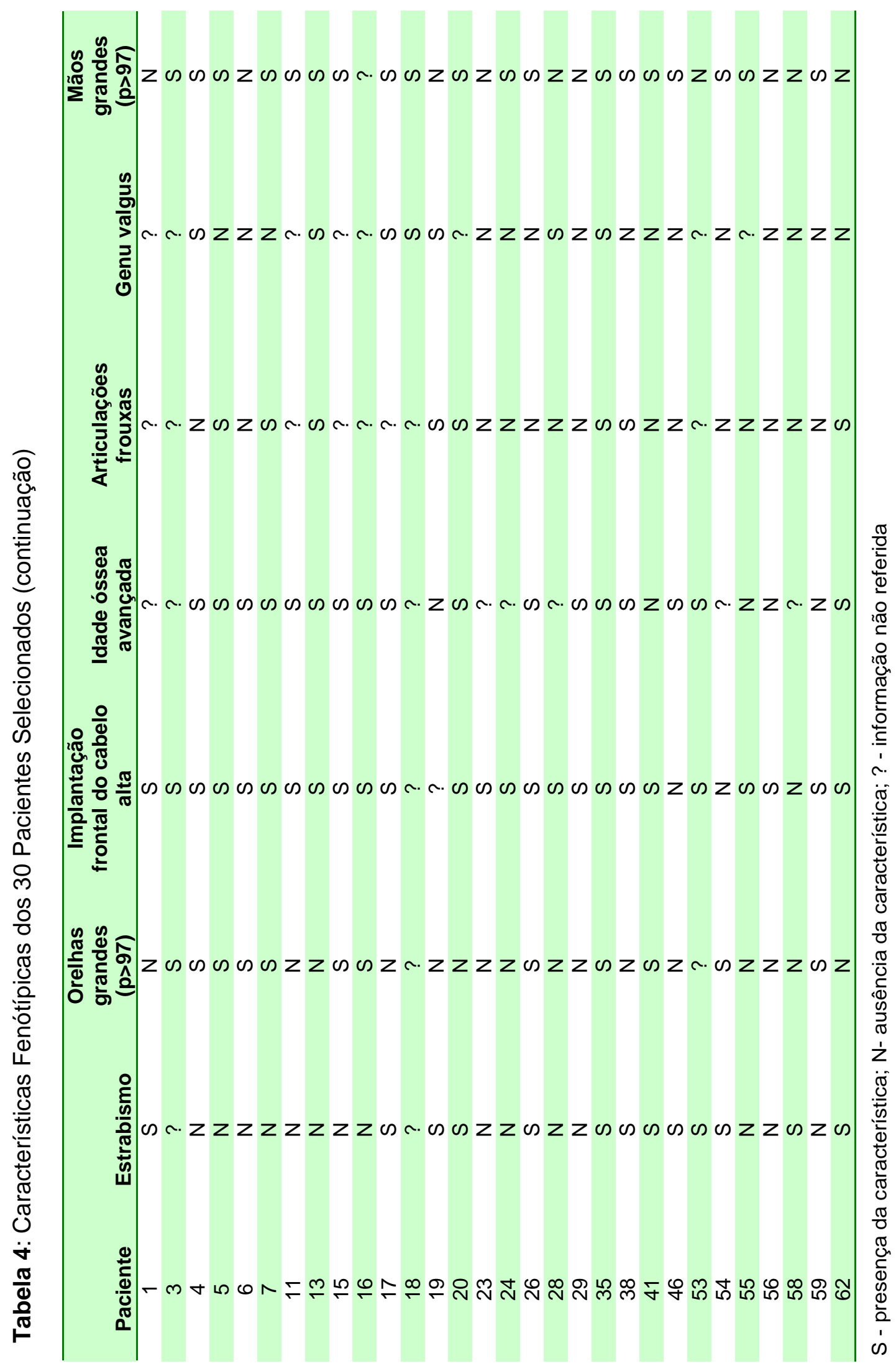




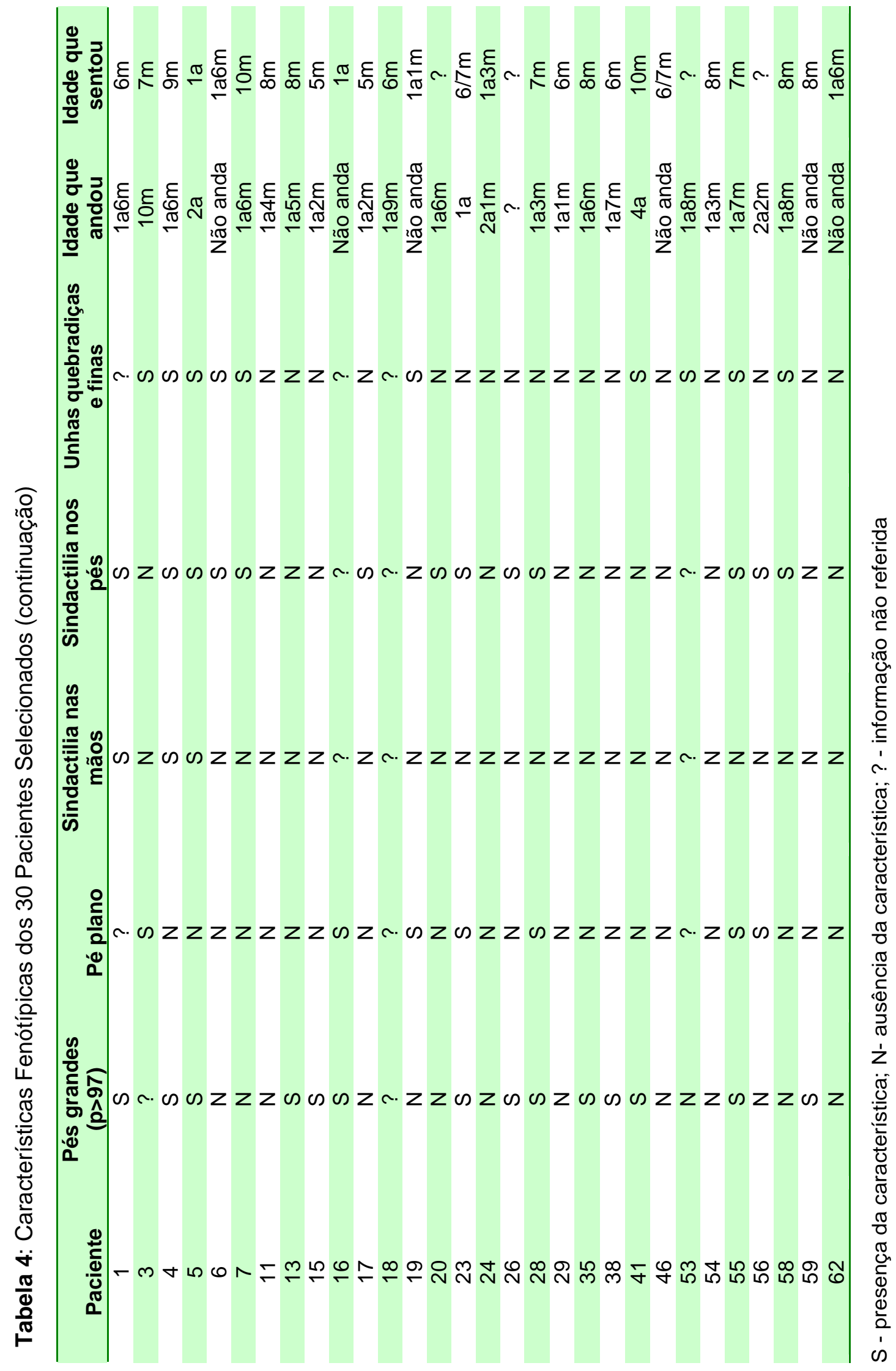




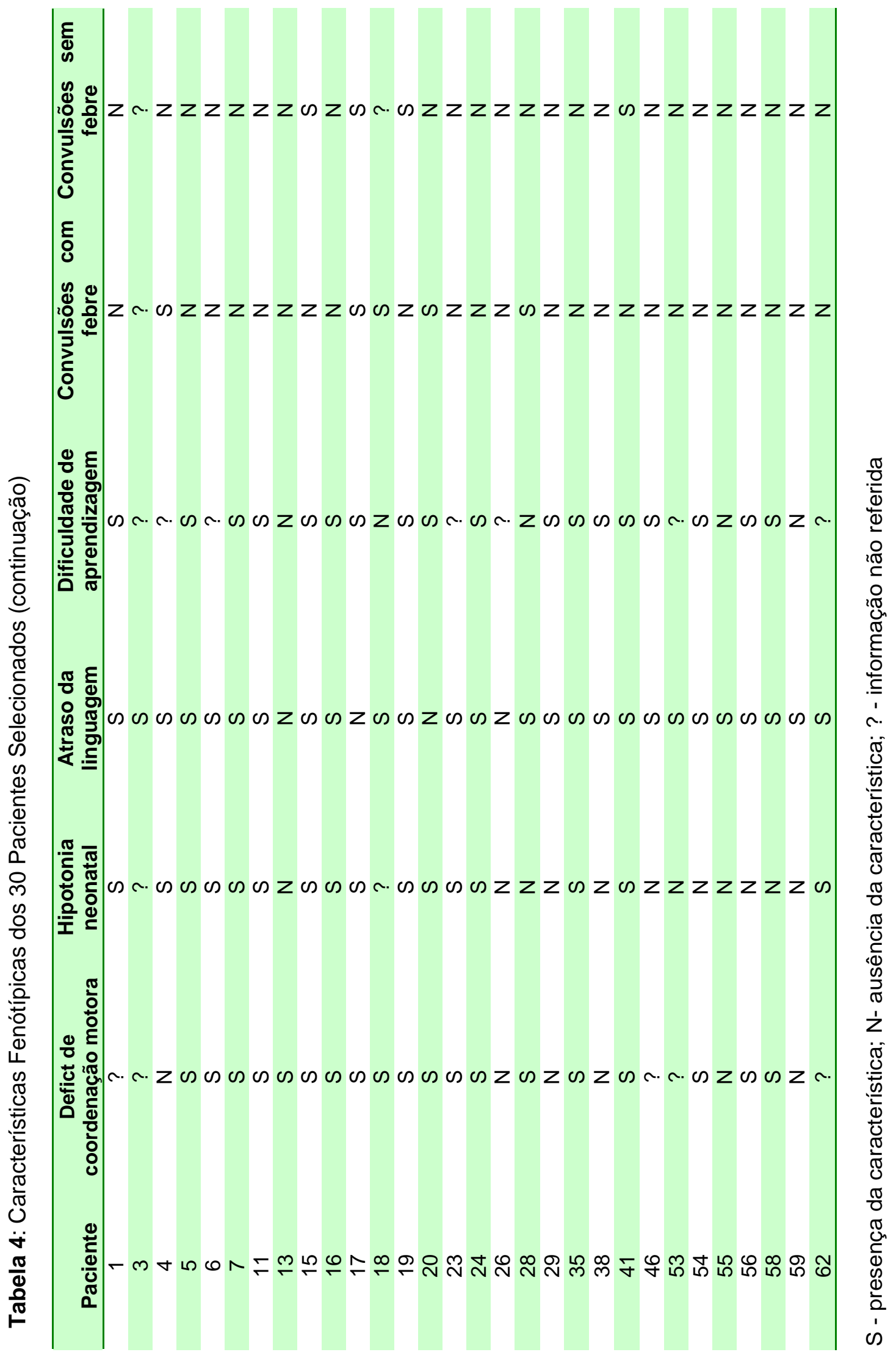




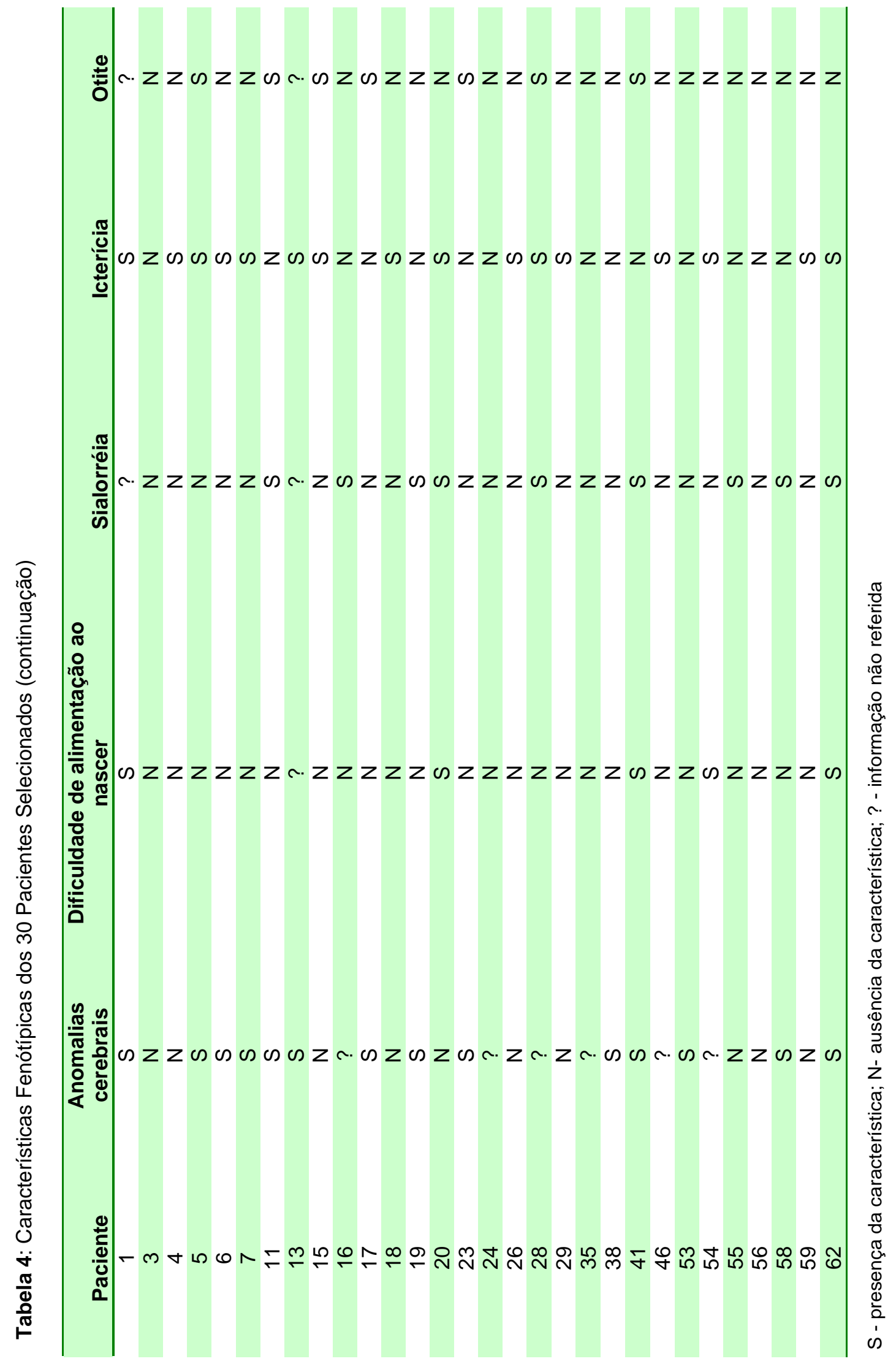




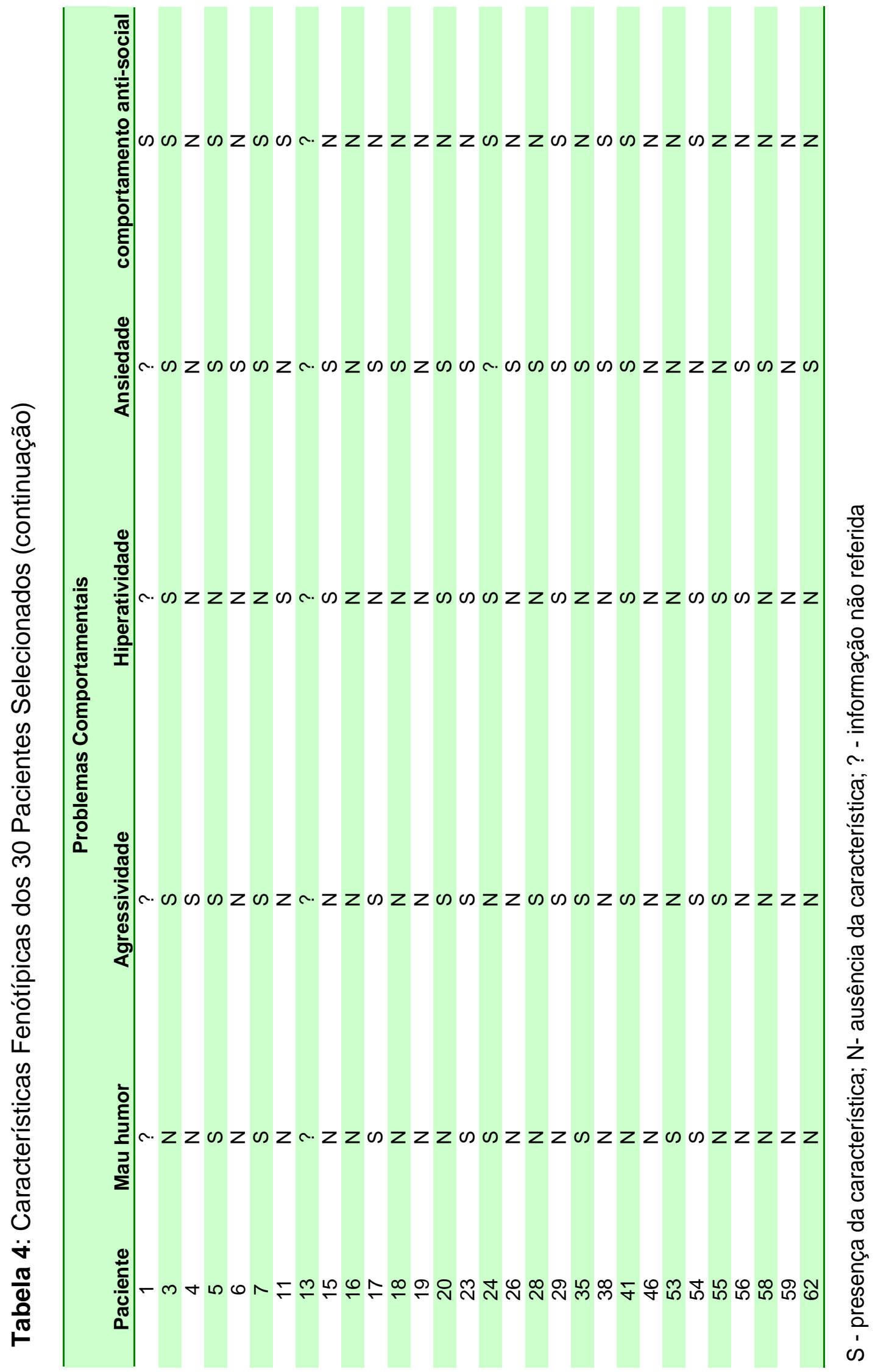




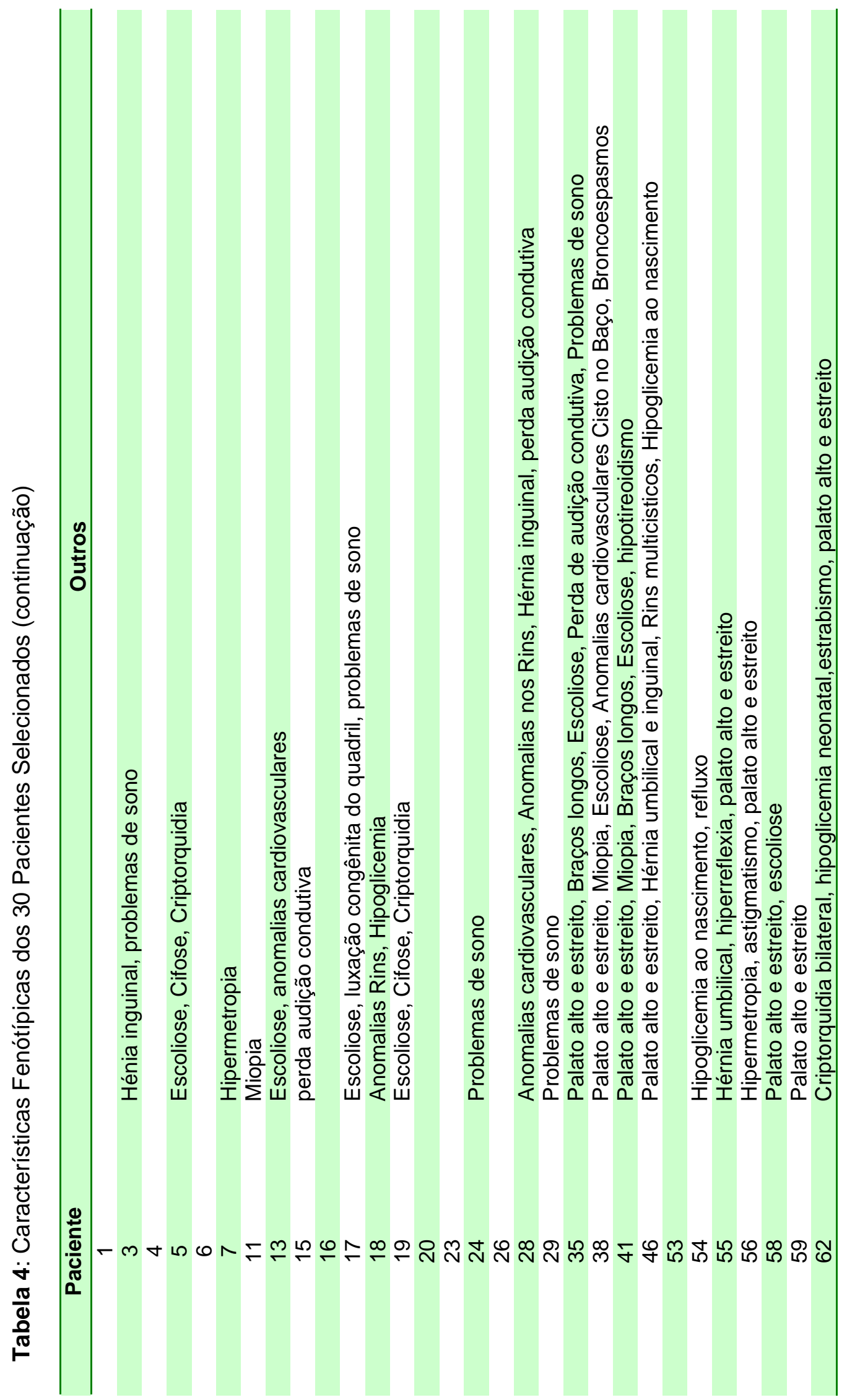



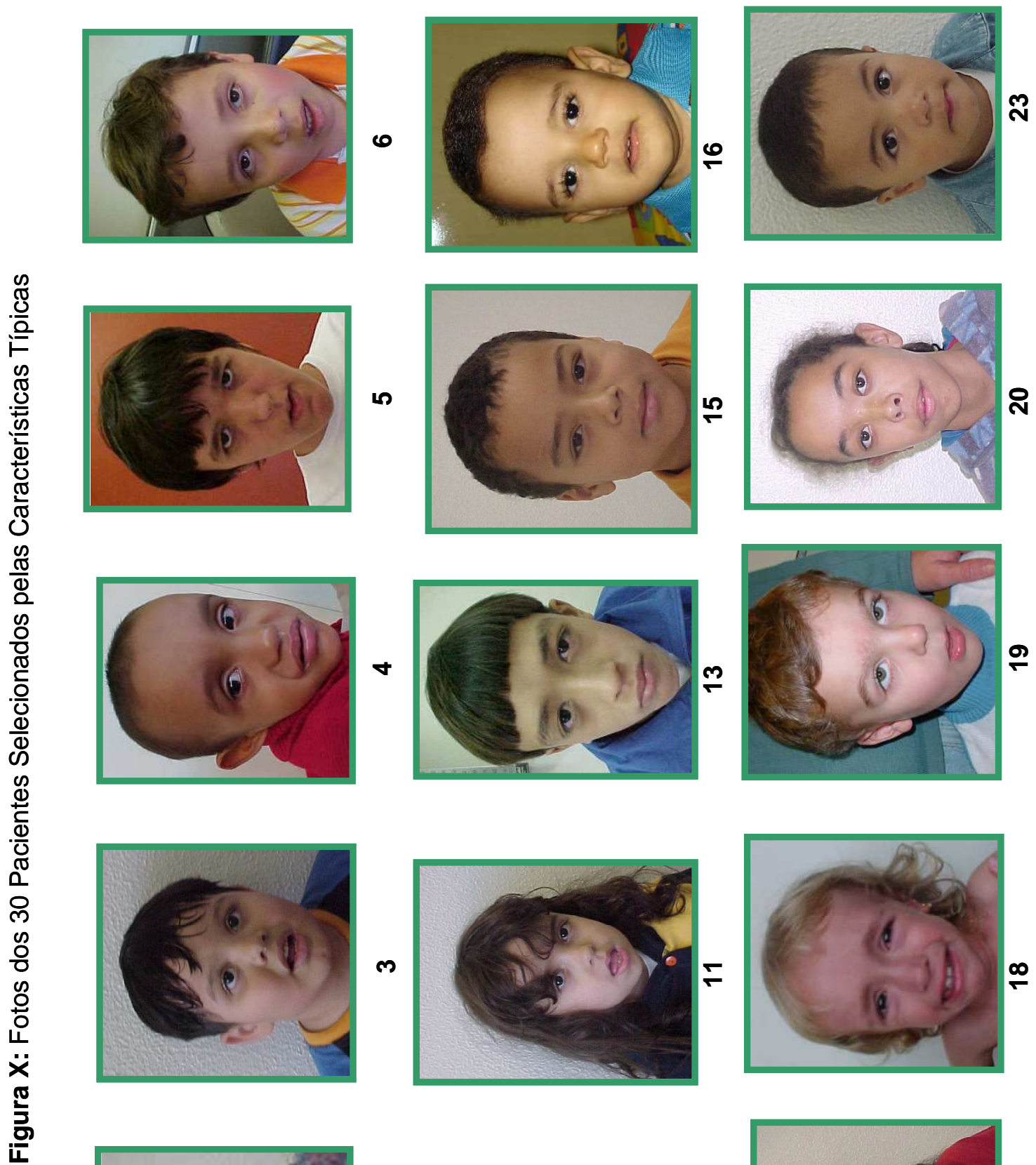

里
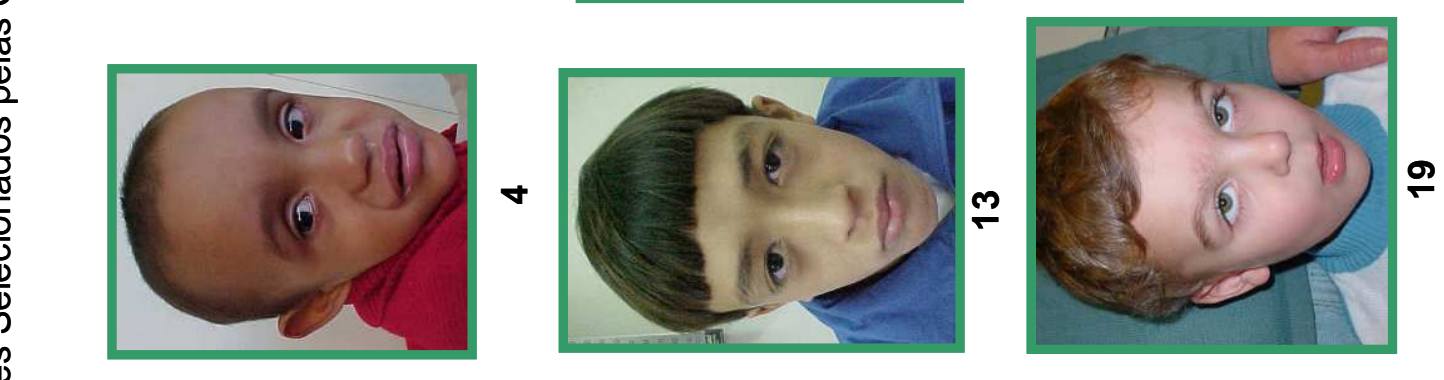

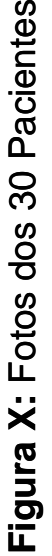
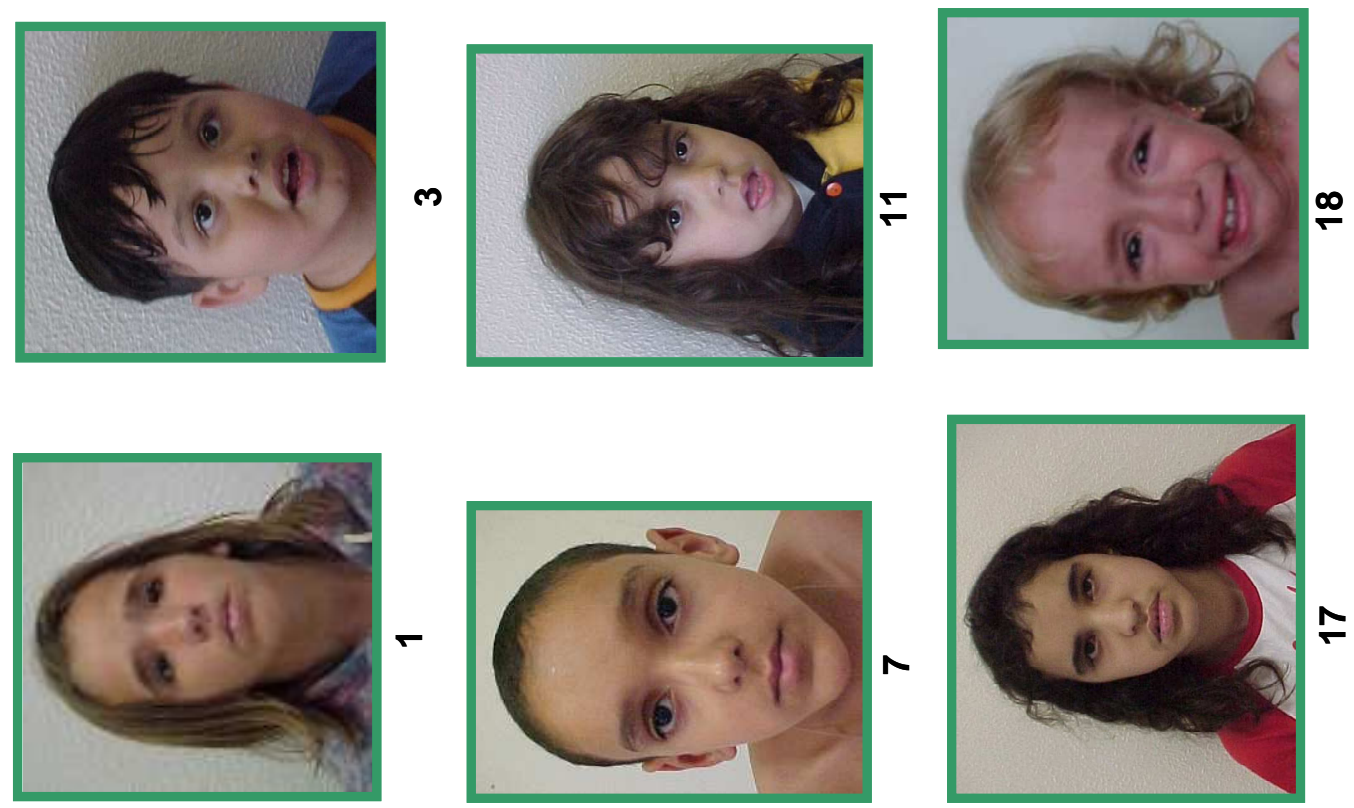


\section{V - Discussão}

\section{V.1 - $\underline{\text { Aspectos genéticos }}$}

\section{V.1.1 - Identificação de deleções}

Para a identificação de deleções, trinta e quatro pacientes foram testados por marcadores de microssatélites, utilizando o "primer" intragênico SOT3 descrito em Douglas et al, (2003). O paciente 21 foi o único a apresentar a deleção para este marcador. A deleção nesse paciente foi confirmada pela técnica de MLPA que mostrou que a deleção do gene NSD1 era total e que havia também a deleção do gene FGFR4.

Deleções de todo o gene NSD1 e regiões flanqueadoras incluindo genes adjacentes, como identificado neste caso, podem ocorrer como conseqüência da presença de duas LCR (low copy repeats) encontradas nos pontos de quebra, uma proximal ou centromérica e outra distal ou telomérica que servem como substrato para a recombinação homóloga não-alélica (NAHR) (Kurotaki, et al, 2005). As LCRs, centromérica e telomérica, do gene NSD1 são de orientação invertida. Mas, uma inversão da subunidade 2B da LCR telomérica pode ocorrer, predispondo à deleção por recombinação homóloga não alélica, (Kurotaki, et al, 2005). Deste modo, a subunidade $2 B$ da LCR telomérica se pareia com a subunidade 2 da LCR centromérica e ocorre a recombinação, resultando em uma deleção ou uma duplicação, como mostra a figura 6 (pagina 26). 
A freqüência desta deleção na nossa amostra é de $1 / 34$, enquanto que a encontrada por Douglas, et al, (2003) foi de 3/37 na população de eurodescendentes.

A origem desta deleção é paterna, assim como a maior parte das deleções descritas são de origem paterna (Miyake, et al,2003). A origem paterna das deleções pode ser explicada, pelo menos em parte, pela posição do telomero em relação ao gene $N S D 1$, levando em consideração que a taxa de recombinação do telomero $5 q$ no cromossomo paterno é bem maior do que no cromossomo materno (Tatton-Brown e Rahman, 2006).

Pela análise por MLPA foram detectados dois casos de deleções parciais, o paciente 2 , em que os exons $1,2,3,4,5,6,7,8,9,10,11,12,13,14,15,16$ e 17, além do gene FGFR4 estão deletados, e o paciente 50, com apenas os exons 13 e 14 deletados. Não há descrições de deleções semelhantes. Segundo Douglas, et al, (2005b), cada deleção parcial tem um tamanho único, sugerindo que as deleções parciais não seriam as causas predominantes da síndrome de Sotos e que para a identificação dessas deleções é necessário a análise do gene todo. Essas deleções são diferentes das deleções de 2Mb que são a causa principal da síndrome de Sotos entre os japoneses.

Os pontos de quebra dessas deleções parciais, como as dos pacientes $2 \mathrm{e}$ 50, podem não estar localizados dentro de elementos repetitivos, como no caso das deleções de $2,2 \mathrm{Mb}$. Nestes casos, pode ter ocorrido uma "junção das extremidades não homólogas" (NHEJ) (figura 7 - página 28). Esse mecanismo foi proposto por Douglas, et al, (2005b) pela observação de pouca homologia entre as seqüências flanquedoras dos pontos de quebra. Entretanto, Visser, et al, (2005), 
encontraram um elemento LINE 1 próximo ao ponto de quebra, sugerindo uma instabilidade genômica nestes locais.

A deleção do paciente 2 também poderia ser explicada pela grande quantidade de seqüências Alu distribuídas no gene NSD1 e ao seu redor, que sofrem recombinação homóloga não alélica (Douglas, et al, 2005b).

Segundo Douglas, et al, (2005b), o gene NSD1 é rico em seqüências Alu com uma densidade de $40,2 \%$ comparado com a de $10,6 \%$ do genoma. Particularmente, o intron 2 contém 115 elementos Alu.

A deleção dos exons 13 e 14 do paciente 50 também pode ser explicada pela recombinação homóloga não alélica entre seqüências Alu. Douglas, et al (2005b) descreveram uma seqüência Alu no intron 13 que resultou em uma deleção incluindo os exons 9-13.

Tanto o paciente 21 como o paciente 2 tem o gene FGFR-4 (fibroblast growth factor receptor-4) deletado.

O gene FGFR-4 faz parte da família dos genes FGFR (fibroblast growth factor receptor) que têm um papel importante na proliferação e diferenciação celular (Citores, et al, 2007), sugerindo que esses pacientes com alterações neste gene possam sofrer problemas de crescimento, como o crescimento acelerado.

Os aspectos clínicos desses três pacientes são bastante semelhantes. 0 paciente 2, com oito meses, apresenta "fácies típica", com abaulamento frontal, queixo proeminente, hipertelorismo e fissura palpebral antimongolóide. A macrocefalia (presente ao nascer), a dolicocefalia, a altura acima do percentil 97 e as mãos grandes também estão presentes. Além disso, foram observados atraso do desenvolvimento neuropsicomotor, icterícia, dificuldade de alimentação, 
hipoglicemia no período neonatal e anomalias cardiovasculares (tabela 1, pagina 64).

No paciente 21, com cinco anos, foram observados a "fácies típica" com abaulamento frontal, queixo proeminente, hipertelorismo, fissura palpebral antimongolóide e estrabismo. A altura está no percentil 97 e há a presença de macrocefalia, dolicocefalia e mãos grandes. O paciente apresenta também sialorréia, "defict" de coordenação, hipotonia neonatal, atraso na linguagem, atraso do desenvolvimento neuropsicomotor, dificuldade de aprendizagem e icterícia. Os distúrbios de comportamento, como agressividade, hiperatividade e ansiedade também estão presentes. Além disso, anomalias cardiovasculares também foram observadas neste paciente.

O paciente 50, com sete anos, apresenta "fácies típica" com abaulamento frontal, queixo proeminente e estrabismo. A altura e o peso estão acima do percentil 97. Foram observados também a macrocefalia (presente ao nascer), a dolicocefalia, o nistagmo, o palato alto e estreito, as mãos e pés grandes e a sindactilia nos pés. Neste paciente a idade óssea está avançada, além de apresentar atraso do desenvolvimento neuropsicomotor, coordenação motora afetada, atraso de linguagem e dificuldade de aprendizagem. Apresentou icterícia e hipotonia neonatal e dificuldade de alimentação ao nascer. Além dos distúrbios comportamentais como comportamento anti-social principalmente em relação a crianças, mau humor, agressividade, hiperatividade e ansiedade, apresenta também problemas de sono.

A partir dos dados clínicos desses pacientes observamos que os três apresentaram "fácies típica" e macrocefalia, com dolicocefalia e mãos grandes 
sugerindo que essas características sejam as principais características para o diagnóstico clínico da síndrome de Sotos. Em contrapartida, os três pacientes nasceram com o comprimento e o peso dentro dos padrões da normalidade, evidenciando que peso e comprimento ao nascimento não fazem parte dos critérios obrigatórios de diagnóstico para a síndrome de Sotos.

Foi proposto por Nagai, et al, (2003) que os aspectos clínicos da síndrome de Sotos deveriam ser classificados em duas categorias: as causadas pela haploinsuficiencia de NSD1 (crescimento acelerado e dificuldade de aprendizagem) e aqueles causados pela deleção de outros genes localizados na região deletada (anomalias cardiovasculares e renais). Na nossa amostra, os pacientes 2 e 21, que tem o gene FGFR4, além do gene NSD1, deletado apresentaram anomalias cardiovasculares. Já o paciente 50 , que tem apenas os exons 13 e 14 deletados não apresenta essa característica, mas o crescimento acelerado e a dificuldade de aprendizagem estão presentes.

Porém, de acordo com Tatton-Brown, et al (2005b), que estudaram 266 pacientes, não existe correlação entre o tamanho das deleções e o fenótipo clínico da síndrome de Sotos.

\section{V.1.2 - Triagem de mutações}

Os trinta pacientes selecionados, pelas suas características típicas, foram seqüenciados em quatro pares de primers referentes ao exon 5: 5A, 5B, 5D e 5E.

Dois SNPs (single nucleotide polymorphism) foram observados, um no fragmento $5 \mathrm{~B}$ e outro no 5D. 
O SNP em 5B ocorreu por uma substituição da base citosina (C) por uma timina ( $\mathrm{T})$. Essa substituição não acarreta em mudança de aminoácido, ou seja, o códon TGC que traduz o aminoácido cisteína mudou para o códon TGT, que também traduz o mesmo aminoácido e, deste modo, não há alteração na proteína.

Neste estudo o genótipo $\mathrm{C} / \mathrm{T}$ foi observado com freqüência de 0,3 . De acordo com o estudo populacional "International HapMap Project" (ensemble, http://www.ensembl.org), esse polimorfismo em heterozigose (C/T) é encontrado nas populações européias com freqüência de 0,288. Nas populações africanas do sub-Saara o genótipo $\mathrm{C} / \mathrm{T}$ tem freqüência de 0,333 . Mas a freqüência mais alta do SNP em heterozigose $(\mathrm{C} / \mathrm{T})$ encontra-se nas populações asiáticas com 0,556. Comparando essas freqüências verificamos que a freqüência encontrada nesta amostra é bastante próxima à encontrada para a população africana.

Identificamos também indivíduos com o genótipo T/T na mesma posição do SNP (C/T). A freqüência do genótipo em homozigose (T/T) nesta amostra foi de 0,06, bem abaixo das freqüências observadas pelo estudo populacional "International HapMap Project". A freqüência de $T / T$ nas populações asiáticas varia de 0,356 a 0,227, na população africana do sub-Saara é de 0,617 e em afroamericanos é de 0,2.

O outro polimorfismo encontrado neste estudo está localizado no fragmento 5D e ocorreu por uma substituição da base citosina (C) por uma base timina (T). Essa substituição alterou o códon CGT para CGC sem alterar a proteína, pois esses dois códons traduzem o aminoácido arginina.

O SNP $\mathrm{C} / \mathrm{T}$ observado em 5D, nesta amostra, foi encontrado com freqüência de 0,23. De acordo com o estudo populacional AGI_ASP Population 
(ensemble, http://www.ensembl.org), esse SNP (C/T) tem freqüência baixa nas populações estudadas. O genótipo C/T apenas foi encontrado na população afroamericana com freqüência de 0,211. Apesar do genótipo C/T apenas ser encontrado na população afro-americana, segundo o estudo AGI_ASP Population, sua freqüência $(0,211)$ é muito próxima da freqüência observada neste estudo $(0,23)$.

Segundo Waggoner e colaboradores (2005), o gene NSD1 tem muitos polimorfismos descritos. Além disso, vários desses polimorfismos são intrônicos e resultam na troca sinônima d e aminoácidos (Douglas, et al, 2003).

O sequenciamento do gene NSD1 não foi concluído.

\section{V.2 - Aspectos clínicos}

O diagnóstico clínico da síndrome de Sotos ainda é um desafio. Muitas características não são específicas para a síndrome de Sotos e podem ser observadas em várias outras síndromes.

A casuística inicial contava com 65 pacientes enviadas ao laboratório com suspeita clínica de síndrome de Sotos. Destes selecionamos trinta pacientes que apresentavam a "fácies típica" (abaulamento frontal, testa proeminente, hipertelorismo, estrabismo, fissura palpebral antimongolóide) e a macrocefalia.

A síndrome vem sendo caracterizada pelo crescimento acelerado pré e pósnatal, idade óssea avançada nos 4 a 5 primeiros anos de vida, retardamento mental ou dificuldade de aprendizagem, macrocefalia e fácies típica (Agwu et al, 1999; Ambler, 2002; Nagai et al, 2003; Kamimura et al, 2003). 
Tatton-Brown, et al, (2005b) estudaram 266 pacientes nos quais o mecanismo genético que deu origem à síndrome de Sotos foi esclarecido. A amostra era composta por 33 pacientes com microdeleção e 233 pacientes com mutações intragênicas. Esses autores dividiram as características clínicas presentes na síndrome de Sotos em três grupos: características essenciais, características principais e outras características. As características essenciais são as encontradas em $90 \%$ ou mais dos pacientes. As características principais são as presentes em $15 \%$ ou mais dos pacientes com síndrome de Sotos. E por último as características encontradas em menos de $15 \%$ dos pacientes.

As freqüências das características clínicas da síndrome de Sotos da nossa amostra e da amostra de Tatton-Brown, et al, 2005b, estão relacionadas na tabela 5 (páginas 92/93).

A partir das freqüências encontradas na nossa amostra, verificamos que as características obrigatórias, ou seja, aquelas que estão presentes em $90 \%$ ou mais dos pacientes, são a "fácies típica", que está presente em 100\% dos pacientes e a macrocefalia observada em $96,6 \%$ dos pacientes. Em Tatton-Brown, et al, (2005b), as características essenciais são quatro: a "fácies típica", a dificuldade de aprendizagem e o crescimento acelerado, com altura acima do percentil 97 e macrocefalia.

A face típica é facilmente reconhecida em crianças de 1 a 6 anos de idade. Em pacientes com sobrepeso a face típica é menos pronunciada porque o formato longo e fino da face é menos aparente (Tatton-Brown, et al, 2004).

A altura acima do percentil 97 foi observada, nessa amostra, em $73 \%$ dos pacientes, sendo classificada como uma característica principal e não uma 
característica obrigatória como relata Tatton-Brown, et al, (2005b) que observaram a estatura acima do percentil 97 em $90 \%$ dos seus pacientes. Porém, Rio, et al, (2003), Turkmen, et al, (2003) e Tatton-Brown e Rahman (2004) relataram que o crescimento acelerado é uma característica menos específica para a síndrome de Sotos e por isso não pode ser considerada uma característica obrigatória. Fato semelhante ao que ocorreu em nossa amostra.

Em $77,2 \%$ dos pacientes desta amostra a idade óssea está avançada. Freqüência próxima à encontrada por Tatton-Brown, et al, (2005b) que descreveu $76 \%$ dos pacientes com idade óssea avançada. Essa característica tanto em nossa amostra como na amostra de Tatton-Brown é considerada como característica principal.

Classificamos a dificuldade de aprendizagem como uma característica principal, pois foi observada em $78,2 \%$ dos pacientes da nossa amostra. Enquanto que em Tatton-Brown, et al, (2005b) essa característica é classificada como obrigatória sendo observada em $97 \%$ dos pacientes. A dificuldade de aprendizagem tem níveis diferentes que podem variar desde uma leve dificuldade até dificuldades graves em que um adulto não é capaz de viver independentemente (Tatton-Brown, et al, 2004). Essa diferença pode ser atribuída ao fato de que na nossa amostra 9 indivíduos ainda não estão em fase de alfabetização e 6 indivíduos ainda não atingiram a idade escolar e por isso não foi possível verificar essa característica.

A hipotonia neonatal é uma característica principal tanto na nossa amostra como na amostra de Tatton-Brown, et al, (2005b). Na nossa amostra a hipotonia neonatal foi observada em $64 \%$ dos pacientes. Enquanto que na amostra de 
Tatton-Brown, et al, (2005b) a característica foi relatada em cerca de $70 \%$ dos pacientes.

A dificuldade de alimentação ao nascer é atribuída por Tatton-Brown, et al, (2005b) à hipotonia neonatal e em sua amostra foi observado que aproximadamente $70 \%$ dos recém-nascidos com síndrome de Sotos apresentaram essa característica. Segundo Tatton-Brown e Rahman (2006) essa dificuldade no período neonatal, geralmente, desaparece com o tempo e não indica problemas a longo prazo. Apesar da alta incidência de hipotonia neonatal em nossa amostra, apenas em 14\% dos indivíduos a dificuldade de alimentação está presente.

Outro problema no período neonatal observado em nossa amostra foi a icterícia que está presente em aproximadamente 53\% dos pacientes, sendo classificada como característica principal. Assim como em Tatton-Brown, et al (2005b) que observaram essa característica em $70 \%$ dos pacientes com a síndrome de Sotos.

As convulsões também são características principais observadas em cerca de $32 \%$ dos pacientes da nossa amostra enquanto que, em Tatton-Brown, et al, (2005b) 25\% dos pacientes apresentaram convulsões.

A escoliose não era reconhecida como uma característica da síndrome de Sotos, entretanto foi observado por Tatton-Brown et al (2004) em $43 \%$ dos pacientes com a síndrome de Sotos e por isso hoje é considerada uma característica clínica associada à síndrome de Sotos. Em nossa amostra a escoliose está presente em cerca de $30 \%$ dos pacientes, freqüência aproximada à relatada por Tatton-Brown, et al, (2005b) de 33\%. É também uma característica classificada como principal. 
As anomalias cerebrais, que foram observadas em $58 \%$ da nossa amostra, foram classificadas como características principais tanto na nossa amostra como na de Tatton-Brown, et al, (2005b).

Anomalias cardíacas, dificuldade de alimentação ao nascer e anomalias renais foram classificadas neste estudo como "outras características" por estarem presentes em menos de $15 \%$ dos pacientes, enquanto que na classificação de Tatton-Brown, et al, (2005b) essas características são consideradas principais.

As anomalias cardíacas podem variar de uma leve lesão que não compromete a função cardíaca até problemas cardíacos complexos em que a cirurgia pode ser necessária (Tatton-Brown, et al, 2004).

Os distúrbios comportamentais, como mau humor, agressividade, hiperatividade, ansiedade e comportamento anti-social, estão presentes em $86,6 \%$ dos indivíduos da nossa amostra, sendo classificados como característica principal. Enquanto que na classificação de Tatton-Brown, et al, (2005b) os distúrbios comportamentais estão classificados como "outras características", ou seja, estão presentes em menos de $15 \%$ dos pacientes. A alta freqüência desta característica em nossa amostra pode ser atribuída ao fato de perguntas específicas sobre comportamento terem sido feitas aos genitores (ficha de anamnese em anexo).

O atraso da linguagem, o "déficit" de coordenação motora, as mãos grandes, a dolicocefalia e os pés grandes estão presentes em mais de $50 \%$ da nossa amostra. Entretanto, Tatton-Brown, et al, (2005b) não mencionou essas características fenotípicas. 
O atraso de desenvolvimento (atraso para andar) foi observado em $31 \%$ da nossa amostra e não foi mencionado por Tatton-Brown, et al, (2005b), entretanto, Waggoner, et al (2005) relatou o atraso de desenvolvimento em $100 \%$ de sua amostra.

Para a suspeita de diagnóstico clinico da síndrome de Sotos a "fácies típica" (gestalt) é essencial sendo acompanhado na maior parte dos casos por macrocefalia. A presença das características principais, ou seja aquelas presentes em $15 \%$ ou mais dos pacientes (altura acima do percentil 97 , anomalias cerebrais, articulação frouxa, atraso da linguagem, comprimento ao nascer acima do percentil 97, convulsões, déficit de coordenação motora, dificuldade de aprendizagem, distúrbios comportamentais, dolicocefalia, genu valgus, hipotonia neonatal, icterícia, idade óssea avançada, macrocefalia ao nascer, mãos grandes, orelhas grandes, otite de repetição, pé plano, pés grandes, peso acima do percentil 97, sialorréia, sindactilia nos pés, unhas quebradiças e finas), não necessariamente todas presentes, devem ser investigadas (tabela 6 - páginas 94/95).

Inclusive, Krepiske-Santos, et al, (2006) relataram um caso em que uma criança do sexo feminino, com 3 anos, que apresentava atraso de desenvolvimento, abaulamento frontal e implantação frontal alto do cabelo, hipertelorismo, fissura palpebral estreita, rotação da orelha incompleta e anomalias no rim esquerdo, era portadora da deleção total do gene NSD1. No entanto, esta paciente não apresentava 0 crescimento acelerado nem a macrocefalia. Portanto, o dismorfismo facial típico da síndrome de Sotos presente em pacientes com ausência de crescimento acelerado e perímetro cefálico normal 
associados à malformações congênitas e/ou retardo mental indicam a pesquisa de microdeleções em 5q35, segmento cromossômico no qual o gene NSD1 está localizado.

A identificação de mutações no gene NSD1 confirma o diagnóstico de síndrome de Sotos. 
Tabela 5: Freqüências das Características Fenotípicas da Nossa Amostra e da Amostra de Tatton-Brown, et al, 2005b

\begin{tabular}{|c|c|c|}
\hline$\underline{\text { Características }}$ & $\begin{array}{l}\text { Nossa } \\
\text { amostra }\end{array}$ & $\begin{array}{l}\text { Tatton-Brown, et al, } \\
\text { (2005b) }\end{array}$ \\
\hline Fácies típica & $100 \%$ & $100 \%$ \\
\hline Macrocefalia & $96,6 \%$ & $90 \%$ \\
\hline Atraso da linguagem & $86,6 \%$ & \\
\hline Distúrbios comportamentais & $86,6 \%$ & \\
\hline Dificuldade de aprendizagem & $78,2 \%$ & $97 \%$ \\
\hline Déficit de coordenação motora & $78 \%$ & \\
\hline Idade óssea avançada & $77,2 \%$ & $76 \%$ \\
\hline Altura acima do percentil 97 & $73 \%$ & $90 \%$ \\
\hline Mãos grandes & $65 \%$ & \\
\hline Hipotonia neonatal & $64 \%$ & $70 \%$ \\
\hline Anomalias cerebrais & $58 \%$ & \\
\hline Dolicocefalia & $56 \%$ & \\
\hline Icterícia & $53 \%$ & $70 \%$ \\
\hline Pés grandes & $50 \%$ & \\
\hline Sindactilia nos pés & $48 \%$ & \\
\hline Orelhas grandes & $43 \%$ & \\
\hline Unhas quebradiças e finas & $37 \%$ & \\
\hline Articulação frouxa & $36 \%$ & \\
\hline Macrocefalia ao nascer & $33 \%$ & \\
\hline Convulsões & $32 \%$ & $25 \%$ \\
\hline Genu valgus & $32 \%$ & \\
\hline Salorréia & $32 \%$ & \\
\hline Escoliose & $30 \%$ & $33 \%$ \\
\hline Palato alto e estreito & $30 \%$ & \\
\hline Pé plano & $26 \%$ & \\
\hline Otite de repetição & $25 \%$ & \\
\hline $\begin{array}{l}\text { Comprimento ao nascer acima do percentil } \\
97\end{array}$ & $20,8 \%$ & \\
\hline Dificuldade de alimentação ao nascer & $14 \%$ & $70 \%$ \\
\hline Problemas de sono & $16,6 \%$ & \\
\hline Hipoglicemia & $13,3 \%$ & \\
\hline Sindactilia as mãos & $11,1 \%$ & \\
\hline
\end{tabular}


Tabela 5: Freqüências das Características Fenotípicas da Nossa Amostra e da Amostra de Tatton-Brown, et al, 2005b (continuação)

\begin{tabular}{|l|l|l|}
\hline Características (continuação) & Nossa & $\begin{array}{l}\text { Amostra tatton-Brown, et } \\
\text { al, (2005b) }\end{array}$ \\
\hline Anomalias cardiovasculares & $10 \%$ & $21 \%$ \\
\hline Anomalias renais & $10 \%$ & $15 \%$ \\
\hline Criptorquidia & $10 \%$ & \\
\hline Hérnia inguinal & $10 \%$ & \\
\hline Miopia & $10 \%$ & \\
\hline Perda de audição condutiva & $10 \%$ & \\
\hline Cifose & $6,6 \%$ & \\
\hline Hérnia umbilical & $6,6 \%$ & \\
\hline Hipermetropia & $6,6 \%$ & \\
\hline Peso acima do percentil 97 & $3,7 \%$ & \\
\hline Peso ao nascer acima do percentil 97 & $3,7 \%$ & \\
\hline "Pads" das mãos proeminentes & $3,3 \%$ & \\
\hline Astigmatimo & $3,3 \%$ & \\
\hline Bronco-espasmos & $3,3 \%$ & \\
\hline Cisto no baço & $3,3 \%$ & \\
\hline Epicanto & $3,3 \%$ & \\
\hline Hiperreflexia & $3,3 \%$ & \\
\hline Hipotireoidismo & $3,3 \%$ & \\
\hline Luxação congênita do quadril & $3,3 \%$ & \\
\hline Refluxo & & \\
\hline
\end{tabular}


Tabela 6: Classificação das Características Fenotípicas da Nossa Amostra Características essenciais (presente em $\geq 90 \%$ dos pacientes)

Fácies típica

Macrocefalia

Características principais (presente em $\geq 15 \%$ dos pacientes)

Altura acima do percentil 97

Anomalias cerebrais

Articulação frouxa

Atraso da linguagem

Comprimento ao nascer acima do percentil 97

Convulsões

Déficit de coordenação motora

Dificuldade de aprendizagem

Distúrbios comportamentais

Dolicocefalia

Escoliose

Genu valgus

Hipotonia neonatal

Icterícia

Idade óssea avançada

Macrocefalia ao nascer

Mãos grandes

Orelhas grandes

Otite

Palato alto e estreito

Pé plano

Pés grandes

Peso acima do percentil 97

Problemas de sono

Salorréia

Sindactilia nos pés

Unhas quebradiças e finas 
Tabela 6: Classificação das Características Fenotípicas da Nossa Amostra (continuação)

Outras características (presente em $\leq 15 \%$ dos pacientes)
Anomalias cardiovasculares
Anomalias renais
Cifose
Criptorquidia
Dificuldade de alimentação ao nascer
Hérnia inguinal
Hérnia umbilical
Hipermetropia
Hipoglicemia
Hipotireoidismo
Luxação congênita do quadril
Miopia
Perda de audição condutiva
Peso ao nascer acima do percentil 97
Sindactilia as mãos
Bronco-espasmos
Cisto no baço
Epicanto
"Pads" das mãos proeminentes
Refluxo
Hiperreflexia
Astigmatimo




\section{VI - RESUMO E CONCLUSÕES}

A síndrome de Sotos (MIM 117550) é caracterizada pelo crescimento pré e pós-natal acelerado, fácies típica com testa proeminente, hipertelorismo, estrabismo, fissura palpebral antimongolóide, as orelhas grandes, o palato alto e estreito, mãos e pés grandes e possibilidade de erupção prematura dos dentes. É também freqüentemente associada com anomalias cerebrais, cardiovasculares e urinárias, e, ocasionalmente, é acompanhado por lesões malignas, como tumor de Wilms e hepatocarcinoma. Com o avanço da idade, a face gradualmente se alonga, o queixo fica mais proeminente, a altura chega próxima ao normal e a macrocefalia não é mais pronunciada.

A casuística total foi de 65 pacientes com suspeita de diagnóstico clínico da síndrome de Sotos. Esses 65 pacientes foram testados por MLPA com o Kit Salsa P026B e três deleções foram encontradas: deleção total do gene NSD1 e regiões flanqueadas, incluindo o gene FGFR4 e dois casos de deleções parciais do gene, uma com os exons 13 e 14 deletados, e outra com deleção desde o gene FGFR4 até o exon 17 do gene NSD1, todas "de novo". Na nossa amostra a freqüência de deleções foi de cerca de $5 \%$, semelhante à observada nas populações nãojaponesas.

Os pacientes com as deleções apresentam a "fácies típica" com abaulamento frontal, o queixo proeminente, a implantação frontal do cabelo alta; a macrocefalia, a dolicocefalia, as mãos grandes; a hipotonia neonatal e a icterícia neonatal também estão presentes nos três pacientes. Entretanto, os três pacientes 
nasceram com o comprimento e o peso dentro dos padrões de normalidade e não acima do percentil 97 como descrito para a Sos.

Para a pesquisa de mutações no gene NSD1, foram selecionados trinta pacientes com "fácies típica" da síndrome de Sotos e macrocefalia. O seqüenciamento até o momento foi realizado em quatro pares de "primers" referentes ao exon 5 do gene NSD1. Dois SNPs foram encontrados, um no fragmento $5 \mathrm{~B}$ e um no fragmento $5 \mathrm{D}$. Os dois SNPs ocorreram por uma substituição da base nitrogenada $\mathrm{C} \rightarrow \mathrm{T}$ e são substituições sinônimas.

A comparação do estudo de Tatton-Brown, et al, (2005b) que analisou as características clínicas e comportamentais de 266 pacientes com síndrome de Sotos, cujo mecanismo genético foi desvendado, com a nossa amostra de 30 pacientes nos permitiu sugerir como critérios mínimos para o diagnóstico clínico da síndrome de Sotos a "fácies típica" (abaulamento frontal, testa proeminente, hipertelorismo, estrabismo, fissura palpebral antimongolóide) e a macrocefalia.

As alterações no gene NSD1 (microdeleções e mutações) são essencialmente específicas para a síndrome de Sotos e, por isso, o diagnóstico genético para qualquer caso em que haja alteração do gene $N S D 1$, é o de síndrome de Sotos. 


\section{VII - ABSTRACT}

Sotos syndrome (MIM 117550) is autosomal dominant condition characterized by prenatal and postnatal overgrowth, macrocephaly and a typical facial gestalt with frontal bossing, hypertelorism, antimongoloid slant of the palpebral fissures, prominent jaw, large ears, high and narrow palate and large hands and feet. The syndrome is also frequently associated with brain, cardiovascular, and urinary anomalies and is occasionally accompanied by malignant lesions such Wilms tumour and hepatocarcinoma.

NSD1 microdeletions were investigated in sixty five patients with clinical diagnosis of Sotos syndrome by multiplex ligation dependent probe amplification ( MLPA, Kit Salsa P026B). We identified one patient with a total deletion of NSD1 and FGFR4, one with NSD1 exon13-14 deletion and another with a deletion that included FGFR4 and NSD1 exon1-17. All deletions were "de novo". In our sample, the frequency of deletions was $\sim 5 \%$, similar to that found in non-Japanese populations.

The clinical features of the three patients with microdeletions are: the typical facial gestalt with frontal bossing, prominent jaw and high anterior hairline; macrocephaly, dolichocephaly, large hands; neonatal hypotonia and jaundice. However, those three patients presented normal length and weight at birth.

Clinical and behavioral features of 30 patients presenting a typical facial gestalt and macrocephaly, cardinal characteristics of Sotos syndrome were described. 
The comparison of the clinical and behavioral features to those described for 266 patients with a genetic diagnosis of Sotos syndrome indicates that a high clinical suspition of Sotos syndrome includes the typical facial gestalt (frontal bossing, hipertelorism, strabismus, prominent jaw, antimongoloid slant of the palpebral fissures) and macrocephaly. Other features associated with Sotos syndrome, such as overgrowth, learning disability, behavioral problems confirms the clinical diagnosis.

NSD1 microdeletion investigations detects only $5 \%$ of the Brazilian patients with Sotos syndrome. Screening for intragenic NSD1 mutations may not be necessary in classic Sotos syndrome cases. However, identification of an NSD1 abnormality is diagnostic of Sotos syndrome. 


\section{VIII.1 - Ficha de Anamnese para Síndrome de Sotos}

\section{Critério de diagnóstico para Síndrome de Sotos}

Crescimento:

( ) Crescimento acelerado pré-natal: exames pré-natal

( ) Comprimento ao nascer (média de $55,2 \mathrm{~cm}$ em gravidez a termo)

( ) Altura atual $(p>97)$

( ) peso ao nascer (média de 3,9 Kg)

( ) peso atual

Face típica:

( ) Macrocefalia : Perímetro Cefálico $(p>97)$ $\mathrm{PC}$ ao nascimento

( ) Dolicocefalia

( ) Abaulamento frontal

( ) Prognatismo

( ) Queixo proeminente

( ) Hipertelorismo

( ) Fissura palpebral antimongolóide

( ) Estrabismo

( ) Hipermetropia

( ) Miopia,

( ) Catarata,

( ) Nistagmos

( ) Orelhas grandes $(p>97)$

( ) Palato alto e estreito

( ) Nariz avermelhado

( ) Bochechas avermelhadas

( ) Implantação frontal do cabelo alta

( ) Erupção prematura dos dentes : idade

Aspectos Estruturais:

( ) Idade óssea avançada

( ) Braços longos

( ) Articulações frouxas

( ) Genu valgus

( ) Mãos grandes ( $p>97)$ ( ) sindactilia

( ) Maturação desarmônica da falange e ossos carpais

( ) Pés grandes ( $p>97)$

( ) Pé plano

( ) Sindactilia

( ) Unhas quebradiças e finas

( ) Escoliose

( ) cifose 
Aspectos Neurológicos:

( ) Atraso no desenvolvimento motor:

( ) Atraso para andar: idade

( ) Atraso para sentar : idade

( ) Coordenação afetada

( ) Retardamento mental variável

( ) Hipotonia neonatal

( ) Hiperreflexia

( ) Atraso da linguagem

( ) Dificuldade de aprendizagem

( ) Convulsões ( ) com febre ( ) sem febre

( ) Anomalias cerebrais

( ) ventriculomegalia

Temperamento: ( ) mal humorado, ( ) agressivo, ( ) Hiperatividade, ( ) Ansioso, ( ) comportamento anti-social

( ) Anomalias cardiovasculares:

Anomalias urogenitais:

( ) Rins: ( ) ausência, ( ) bífido, ( )outros

( ) Bexiga/ ureter/ uretra

( ) Criptorquidia

( ) Redução dos testículos

( ) Hérnia inguinal

Neoplasias:

( ) Tumor de Wilms

( ) Hepatocarcinoma

( ) Outros

Outros:

( ) Luxação congênita do quadril

( ) Dificuldade de alimentação ao nascer

( ) Sialorréia

( ) Icterícia

( ) Hipoglicemia

( ) Hipotiroidismo

( ) Problemas de sono

( ) Otite

( ) Perda de audição condutiva 
VIII.2 - Ficha de Anamnese Geral

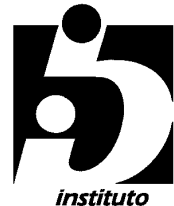

UNIDADE DE ACONSELHAMENTO GENÉTICO

FICHA DE ANAMNESE GENÉTICA

NOME:

UAG oo

IDADE:

SEXO: ( ) F ( ) M COR:

EST.CIVIL:

FONE:

ENDEREÇO:

PROCEDÊNCIA.:

MÉDICO: Dr(a)

MOTIVO DA CONSULTA:

H.C. RG no:

\section{ANTECEDENTES FAMILIAIS}

PAI:

IDADE:

PROFISSÃO:

ESCOLARIDADE:

NATURAL DE:

MÃE:

IDADE:

PROFISSÃO:

ESCOLARIDADE:

NATURAL DE:

CONSANGÜINIDADE:

Irmãos do Propósito (nome, idade, estado civil, filhos normais e afetados): 


\section{Outros Problemas na Família:}

Irmãos do Pai (nome, idade, estado civil e filhos normais e afetados):

Irmãos da Mãe (nome, idade, estado civil e filhos normais e afetados):

OBSERVAÇÕES:

\section{HEREDOGRAMA:}




\section{ANTECEDENTES GESTACIONAIS}

Duração da Gravidez: Data de Nascimento:

Febres ( ) Período: Rubéola:

Período:

Outras Infecções:

Período:

Radiografias toráxicas ou abdominais ( ) Período:

Outras exposições à radiação:

Perdas sangüíneas ( ) Período: Medicações ( ) Motivo:

Tipo: Período: Anovulatórios ( ) Tipo: Período:

Anticonvulsivo ( ) Tipo: Período: Sofre de gota ( )

Remédio: Período: Mãe Fumante ( ) Período Gestação:

Quantidade: Pai Fumante ( ) Quantidade:

Mãe Alcoólatra ( ) Período Gestação: Quantidade:

Pai Alcoólatra ( ) Quantidade:

Consumo de drogas mãe ( ) Período Gestação:

Pai ( ) Quantidade: Quantidade: Tipo: ...... Tipo:

OBS.:

\section{PARTO}

Hospitalar ( ) Domiciliar ( ) Médico ( ) Parteira ( ) Curiosa ( ) Normal ( ) Apresentação Tipo: Fórceps ( ) Duração:

Cesariana ( ) Motivo:

OBS.:

\section{CONDIÇÕES DO RECÉM-NASCIDO}

Peso: Comprimento:

P.C.: Choro ( )

Sucção: Cianose ( ) Perm. na Matern.:

Icterícia ( ) Época: . Banho de Luz ( ) Transfusão ( ) OBS.:

\section{EVOLUÇÃO PEDIÁTRICA}

Firmou a cabeça: Sentou sem apoio: Andou: Frases:

Controle (esfincteriano): Bexiga:

D ( ) N ( ) Entrou na escola (idade):

Doenças pertinentes : 
Lê: Escreve:

Faz Contas:

OBS.

\section{EXAME SOMATOSCÓPICO}

Estatura:

Peso:

Envergadura:

Cabeça: PC

Dolicocefalia ( ) Braquicefalia ( ) Assimetria craniana ( ) Crânio dismórfico ( ) Alterações:

Abaulamento frontal ( ) Fronte alta ( ) Baixa ( ) Estreita ( ) Larga ( ) Implantação de cabelos na fronte: Baixa ( ) Alta ( ) Entradas temporais ( ); Implantação de cabelos na nuca: Baixa ( )

OBS.:

\section{ORELHAS}

Grandes ( ) Pequenas ( ) Medida: ........................... Implantação baixa ( ) Posteriorizada ( ) Apêndices auriculares ( ) Em abano ( ) Grosseiras ( ) Lóbulo:

OBS:

\section{REGIĀO OCULAR}

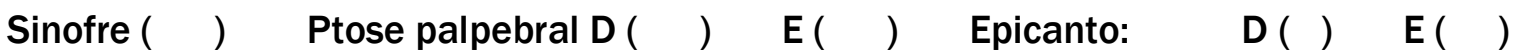
Telecanto: D( ) E( ) Anoftalmia: D( ) E( ) Microftalmia: D( ) E( ) Exoftalmia: D( ) E( ) Enoftalmia: E( ) E ( ) Blefarofimose: D( ) E( ) Nistagmo（）Cataratas: D（）E（）Estrabismo: D（）E（）Coloboma: D（）E（ ) Distância Intercantal Interna: Distância Intercantal Externa: Inclinação: Mongólica ( ) Antimongólica ( ) OBS.:

\section{$\underline{\text { NARIZ }}$}

Grande( ) Pequeno( ) Em Sela( ) Narinas Antivertidas( ) Em bico( ) Bífido( ) Hipoplasia alar( ) OBS.:

\section{REGIÃO BUCAL}

Microstomia ( ) Macrostomia ( ) Micrognatismo ( ) Macrognatismo ( ) Prognatismo ( ) Retrognatismo ( ) Boca de carpa ( ) Lábio leporino ( ) 
Lábio superior: Grosso ( ) Fino ( ) Lábio inferior: Grosso ( ) Fino ( ) Macroglossia ( ) Língua escrotal ( ) Pálato: Alto ( ) Ogival ( ) Pálato fendido ( ) Dentes mal implantados ( ) Inclusos ( ) Maloclusão ( ) Filtro: Medida: Curto ( ) Longo ( ) Alargado ( ) Bem desenhado ( ) liso ( ) hiperplasia gengival ( ) Início de dentição:.

OBS.:

PESCOÇO

Curto ( ) Grosso ( ) Alado ( ) OBS.:

\section{TÓRAX}

PT: Distância Intermamilar:

Esterno Curto ( ) Pectus: carinatum ( ) escavatum ( ) em barril ( ) Afastamento dos mamilos ( ) mamilos extras ( ) escápulas salientes ( ) escoliose ( ) lordose ( ) cifose ( )

OBS.:

\section{ABDÔMEN}

Protuso ( ) Hérnia umbilical ( ) Diastases do reto ( )

OBS.:

Região glútea:

\section{GENITAIS}

Normais ( ) Hipogenitalismo ( )

OBS.:

\section{MEMBROS SUPERIORES}

MÃOS: Pequenas（） Grandes （） Medida:

Braquidactilia ( )

Aracnodactilia ( ) Polidactilia ( ) Tipo: Clinodactilia ( )

Tipo: Camptodactilia ( ) Tipo: Sindactilia ( ) Tipo:

Baqueteamento ( ) Cúbito valgo ( )

OBS.:

\section{MEMBROS INFERIORES}

PÉS: Pequenos ( ) Grandes ( ) Medida:

Polidactilia ( ) Tipo: .............. Sindactilia ( ) Tipo: 
Dist. maior halux $2^{0}$ dedo $($ ) Pé torto $($ ) Tipo:

Pé Plano ( ) Joelho valgo ( ) Joelho varo ( )

OBS.:

\section{PELE E ANEXOS}

Albinismo ( ) Vitiligo ( ) Hemangiomas e teleangectasias ( ) Nevos ( )

Alopecia ( ) Hirsutismo ( ) Deformidade das unhas ( ) Tipo:

Manchas ( ) Tipo:

OBS.:

\section{CONDICÕES GERAIS}

Fácies:

Fala:

Marcha:

Movimentos involuntários:

Hipotonia ( ) Hipertonia ( )

INFORMANTE (Parentesco):

Reações emocionais: Tranqüila ( ) Ansiosa ( )

Condições cognitivas: Congruente ( ) Incongruente ( )

Exames indicados:

Resultados:

Cromatina $X$

Cromatina $Y$

Cariótipo: simples ( ) bandeamento ( ) Dermatóglifos

Heredograma (confirmação)

Fotografia

Outros

Exames clínicos solicitados:

Exame de progenitores:

Características principais do paciente:

Hipótese Diagnóstica: 
VIII.3 - Termo de Consentimento Livre e Esclarecido

Universidade de São Paulo

Instituto de Biociências

\section{TERMO DE CONSENTIMENTO LIVRE E ESCLARECIDO}

(menores de 18 anos)

ESTUDO: "Síndrome de Sotos: pesquisa de microdeleções e mutações intragênicas no gene NSD1".

Seu filho está sendo convidado a participar do projeto de pesquisa acima citado. $O$ documento abaixo contém todas as informações necessárias sobre a pesquisa que estamos realizando. Se concordar com as informações abaixo, por favor, assine o documento, pois só então daremos início a pesquisa.

Eu portador do RG , concordo de livre e espontânea vontade que meu(minha) filho(a) , seja voluntário

do estudo "Síndrome de Sotos: pesquisa de microdeleções e mutações intragênicas no gene NSD1", esclareço que obtive todas informações necessárias e fui esclarecido(a) de todas as dúvidas apresentadas.

I) O estudo se faz necessário para que possam descobrir as possíveis causas da doença denominada síndrome de Sotos e de seus diagnósticos diferenciais;

II) Será feita a coleta de $10 \mathrm{ml}$ de sangue do(a) meu(minha) filho(a) e $10 \mathrm{ml}$ do meu sangue para que seja realizado o estudo;

III) O material colhido será armazenado pelo tempo necessário para a identificação e caracterização do(s) gene(s) ou segmentos cromossômicos responsáveis pela doença genética na minha família; 
IV) A participação neste projeto não tem a finalidade de chegar a um tratamento para os problemas clínicos meu (minha) filho(a);

V) Não terei que fazer pagamentos pelos testes realizados para a pesquisa dos diagnósticos diferenciais;

VI) Tenho a liberdade de desistir ou interromper a colaboração neste estudo no momento em que desejar, sem necessidade de qualquer explicação;

VII) A desistência de participar do projeto não irá interferir na realização de outros exames diagnósticos que por acaso se fizerem necessários;

VIII) Os resultados obtidos na pesquisa serão mantidos em sigilo, mas concordo que sejam divulgados em publicações científicas, desde que nem o meu nome nem o de meu filho sejam mencionados;

IX) Caso eu desejar, poderei tomar conhecimento dos resultados ao final desta pesquisa

( ) Desejo conhecer os resultados desta pesquisa

( ) Não desejo conhecer os resultados desta pesquisa

São Paulo,

de

de 200

\section{Assinatura do Responsável}




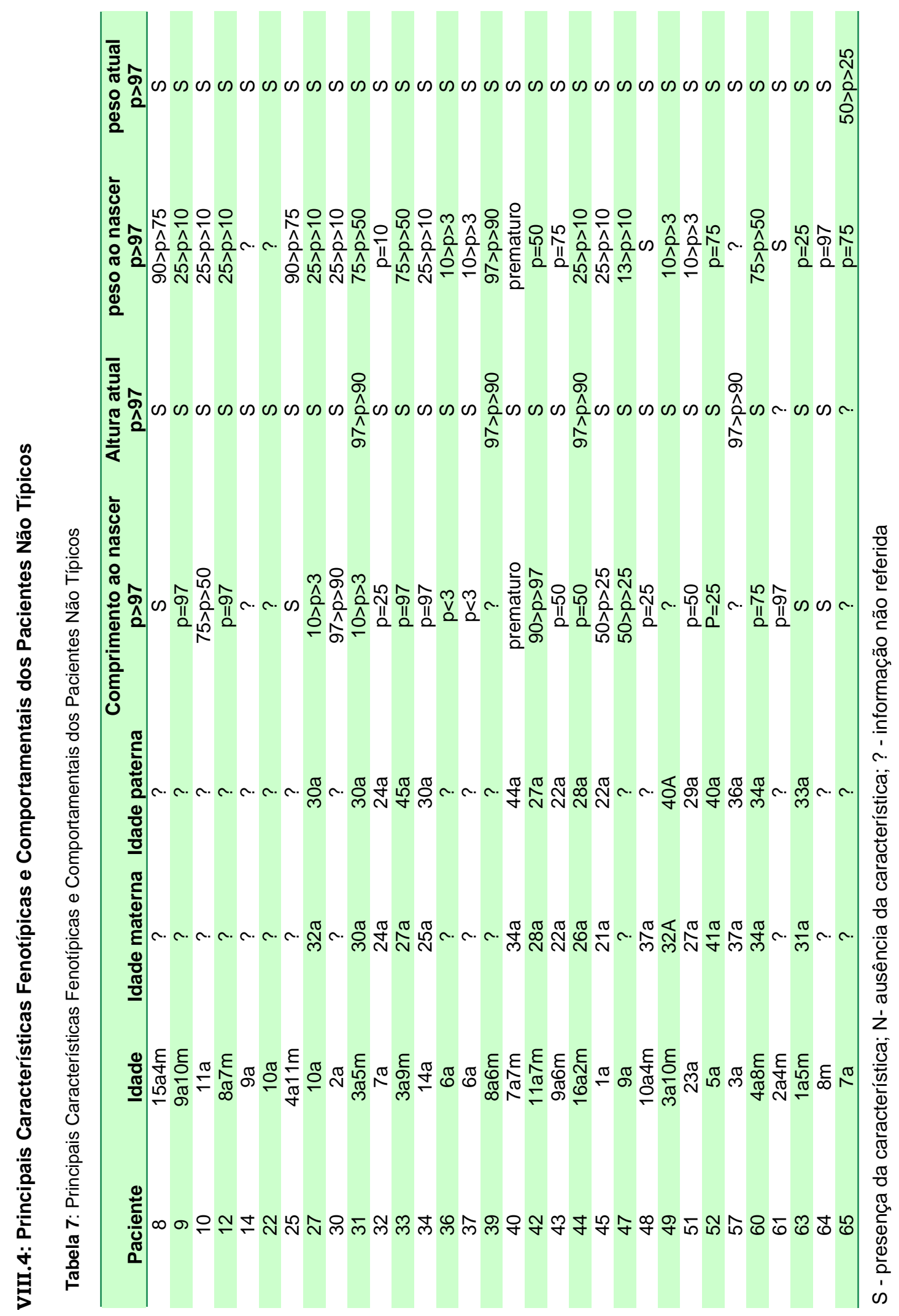




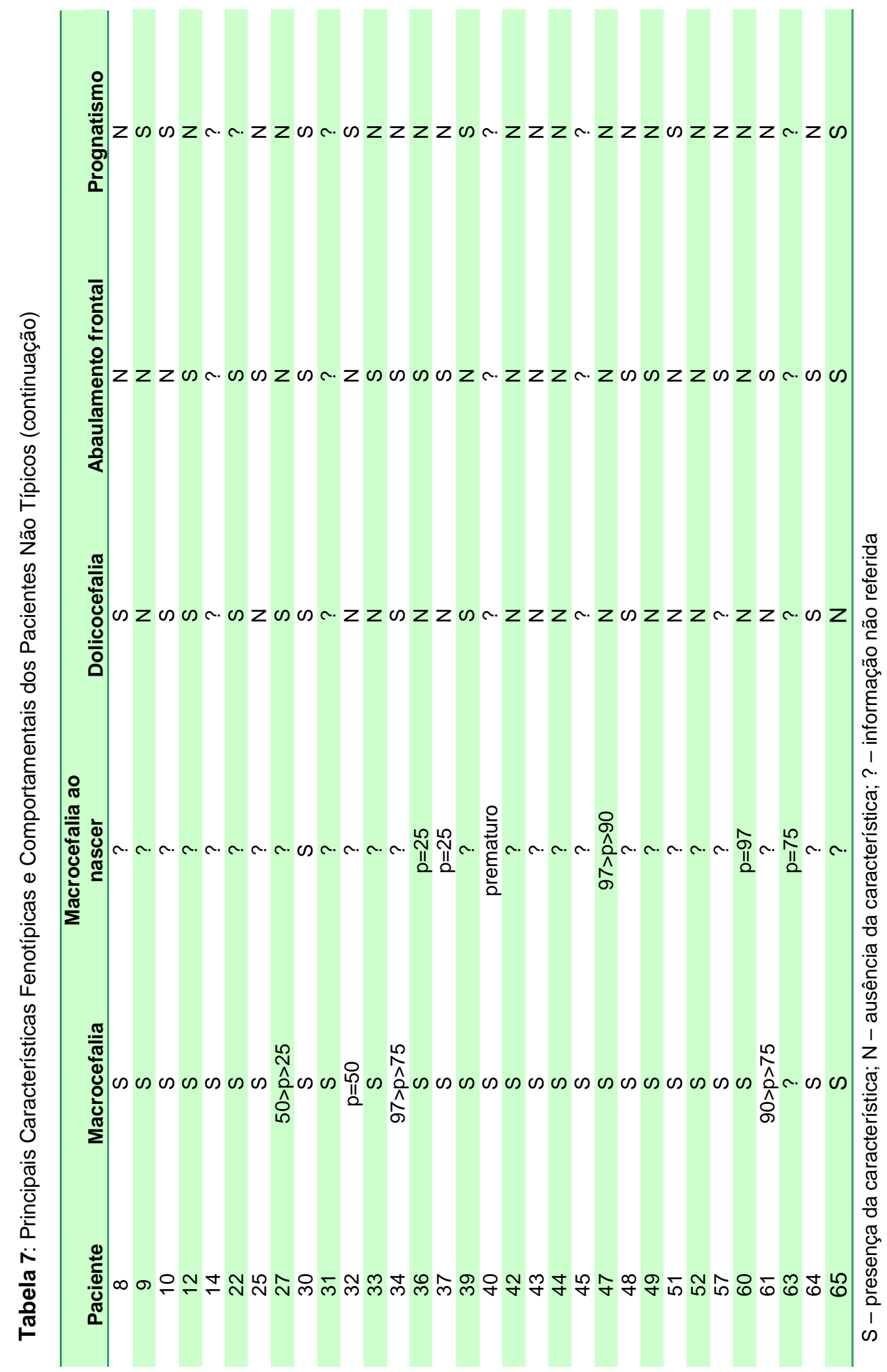




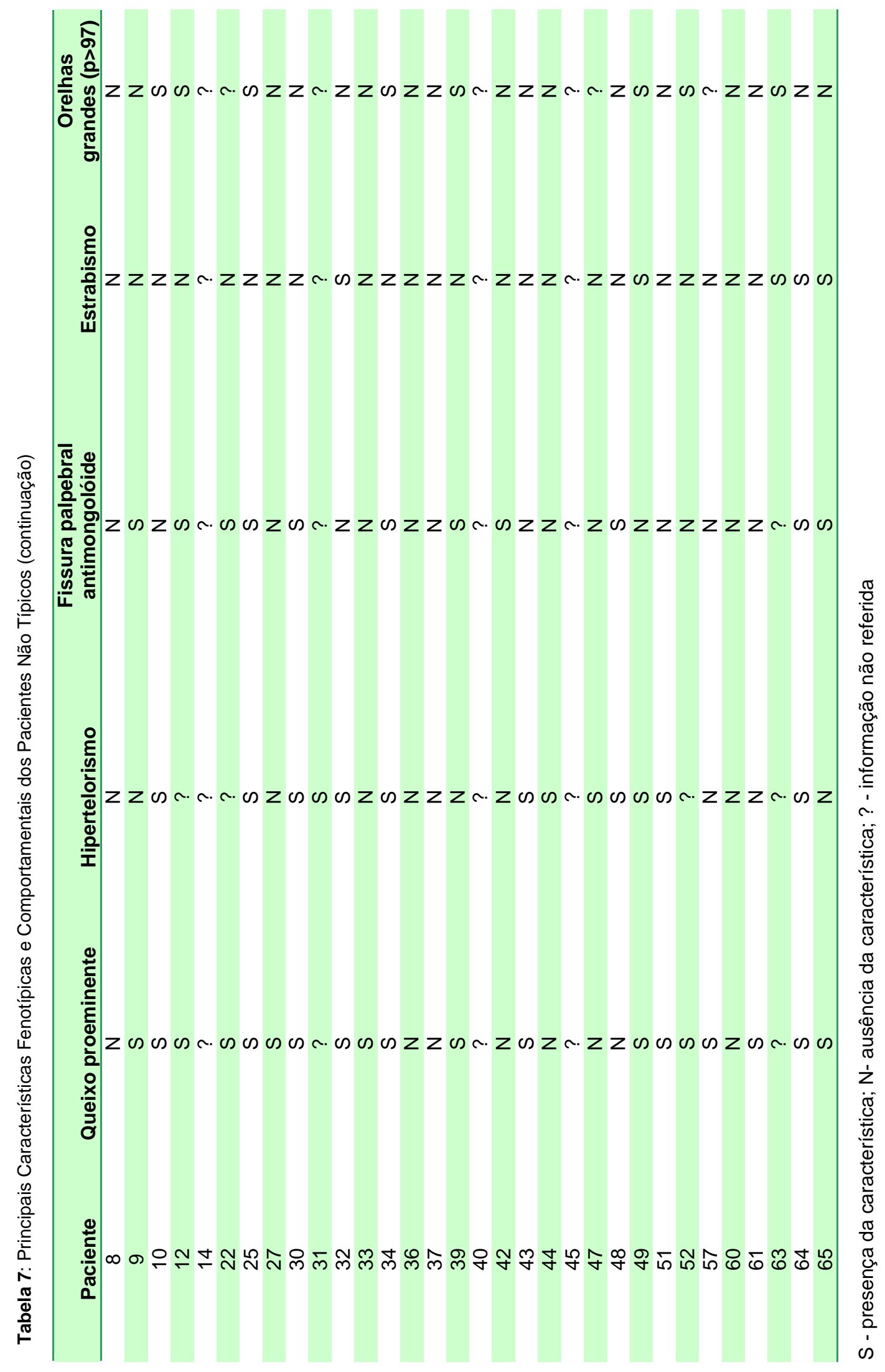




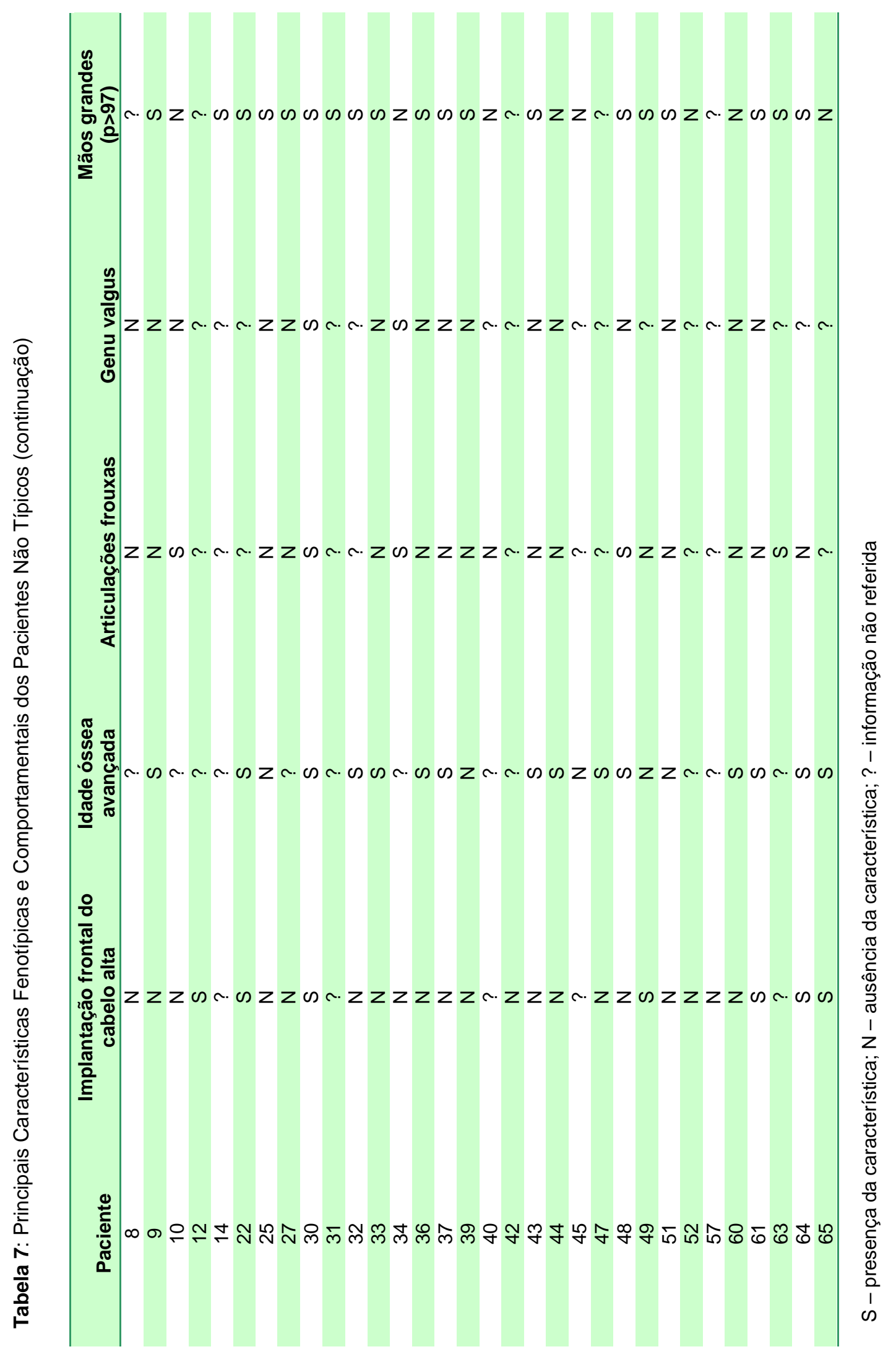




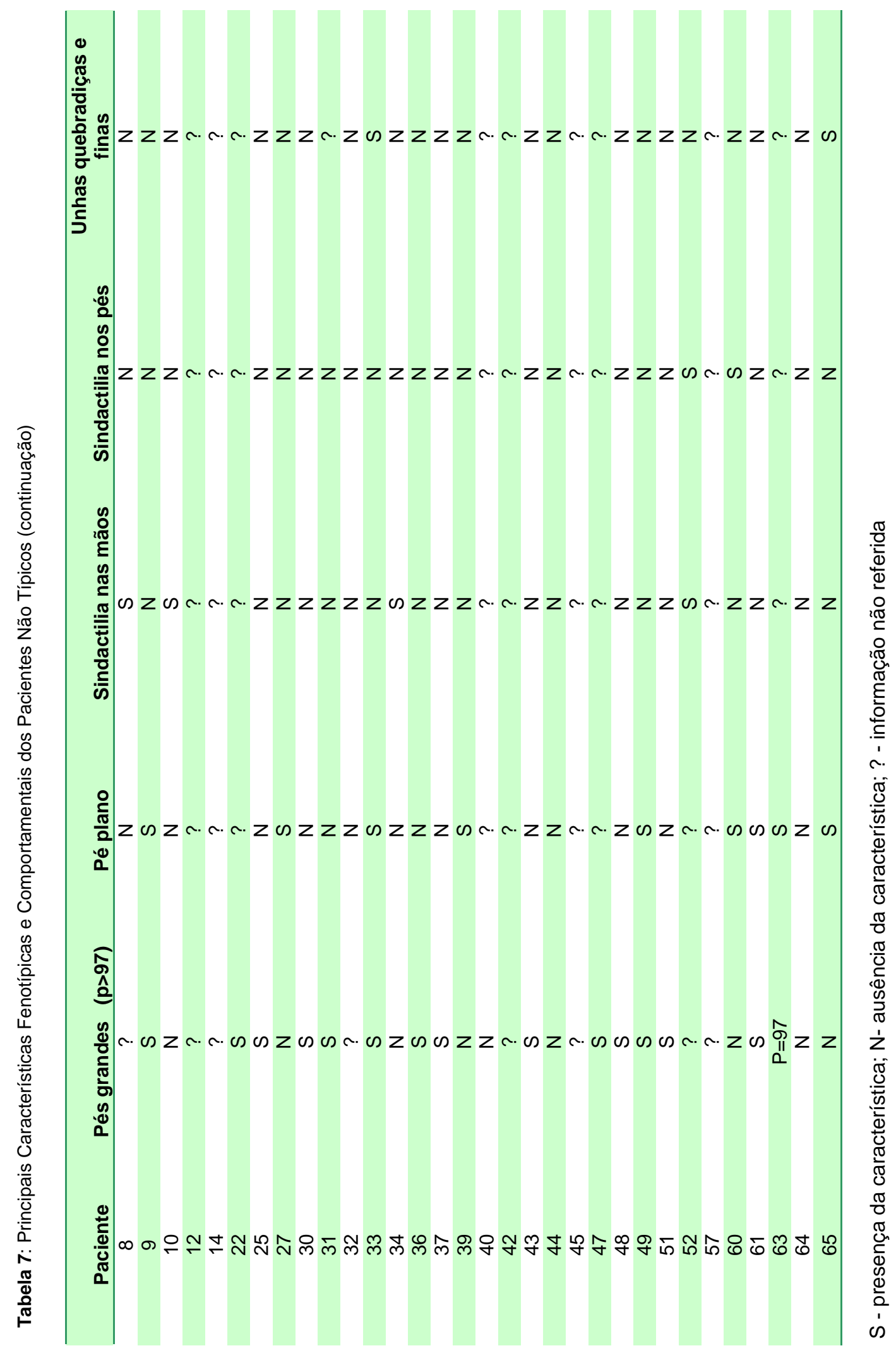




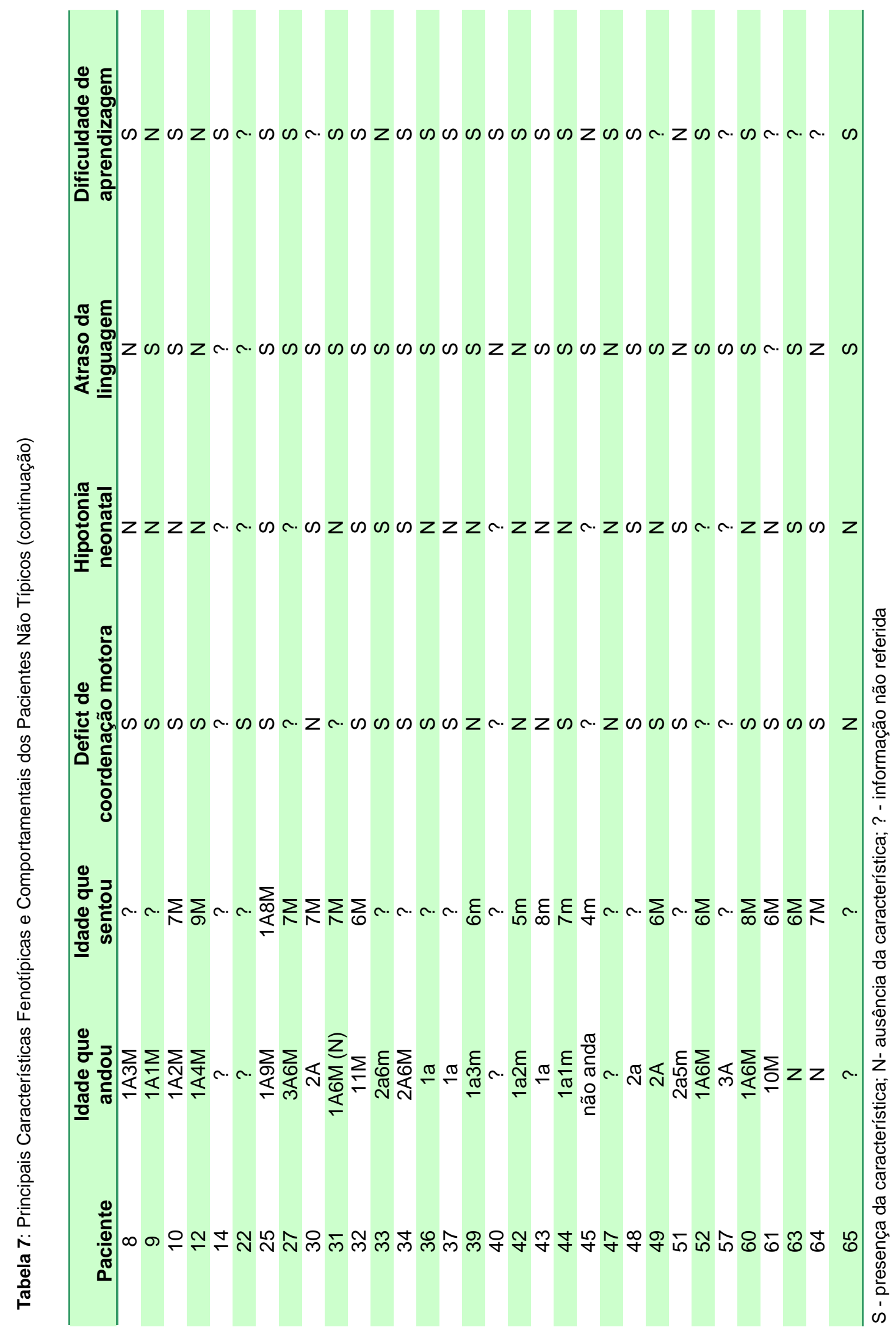




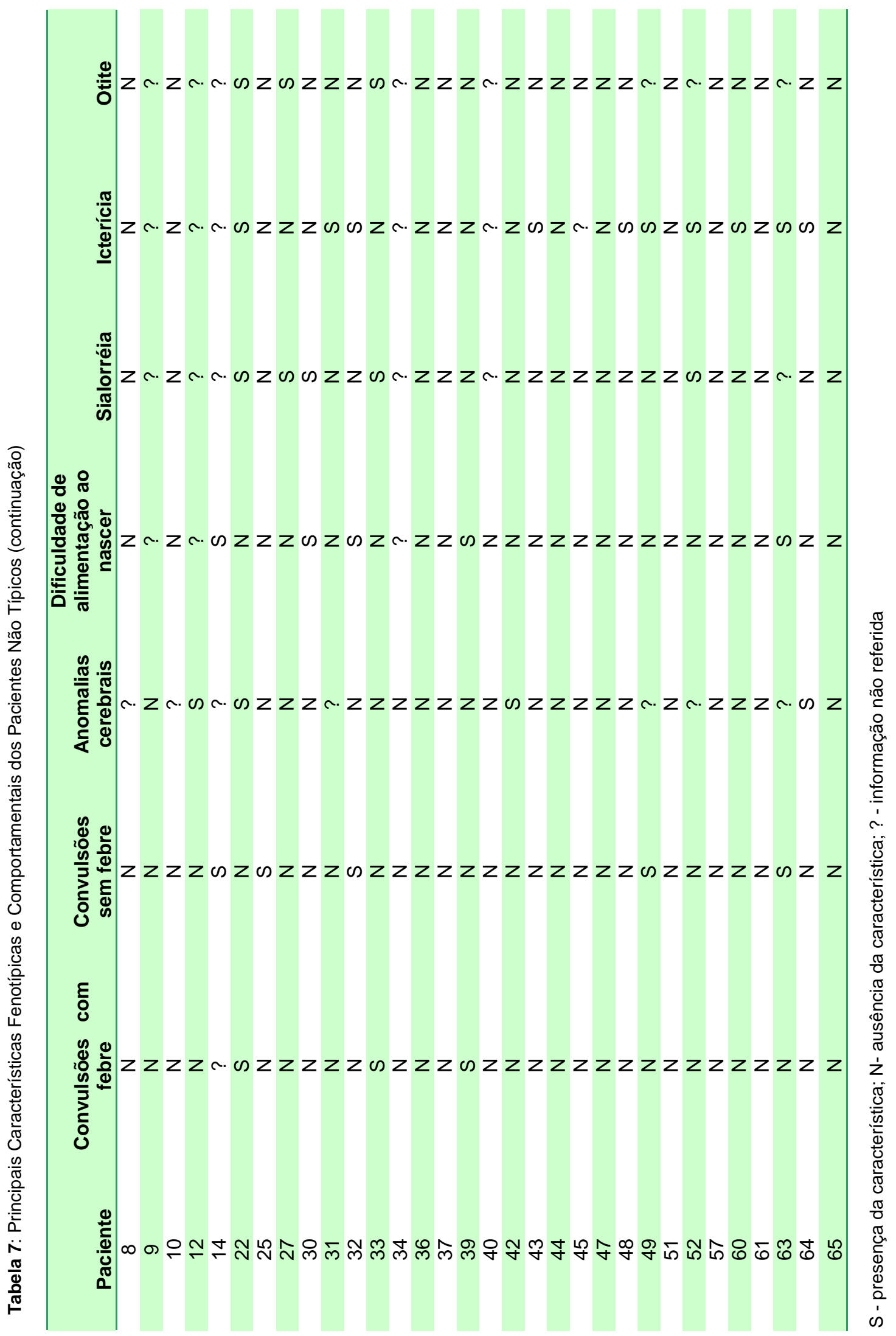




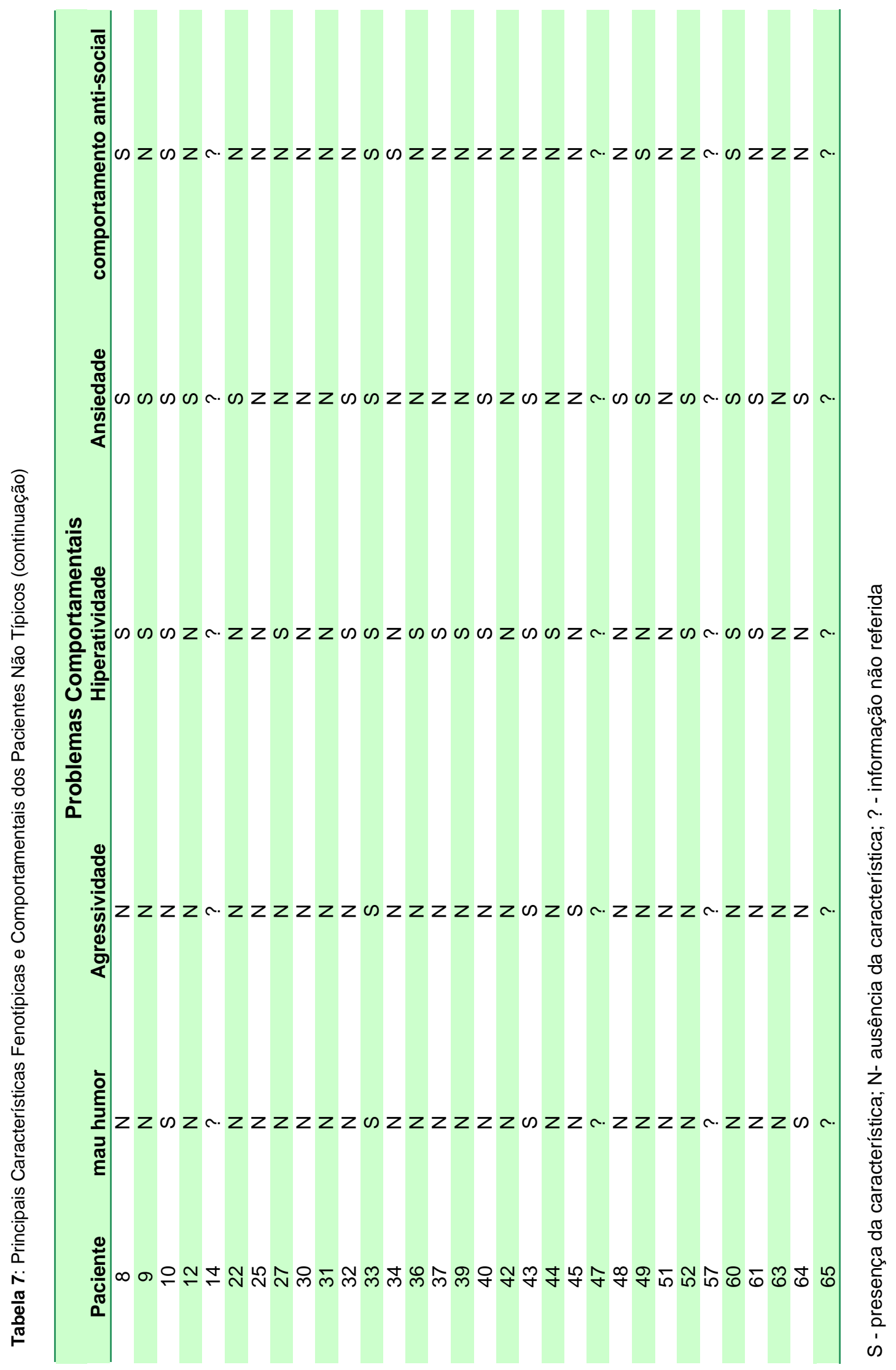




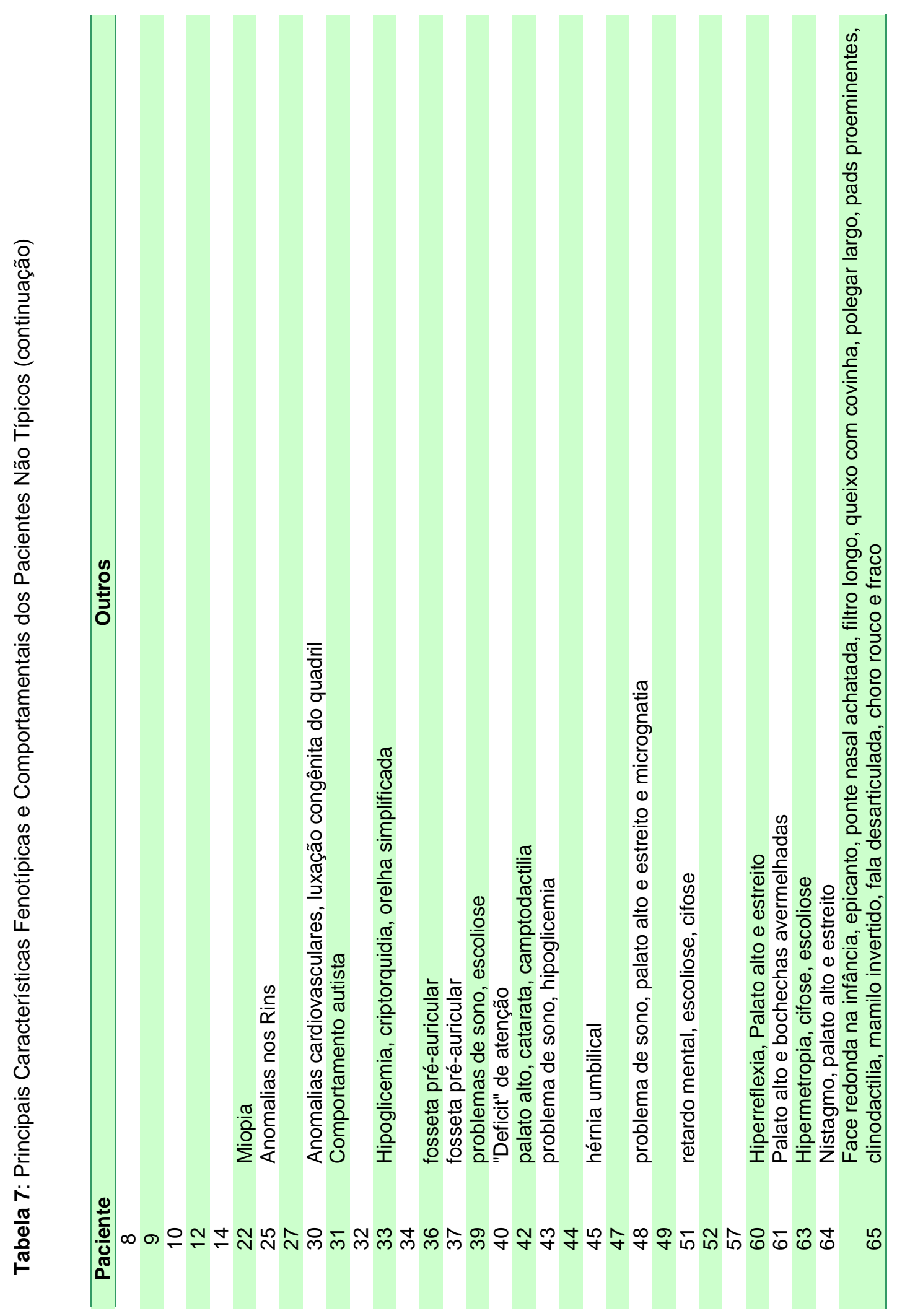


VIII.5 - Freqüências das características fenotípica dos pacientes não-típicos

Tabela 8: Freqüências das características fenotípica dos pacientes não-típicos

\begin{tabular}{|c|c|}
\hline Características clínicas & $\%$ \\
\hline Comprimento ao nascer $p>97$ & 15,4 \\
\hline Altura atual $p>97$ & 86,6 \\
\hline Peso ao nascer $p>97$ & 7,1 \\
\hline Peso atual $p>97$ & 96,9 \\
\hline Macrocefalia & 87 \\
\hline Macrocefalia ao nascer & 0 \\
\hline Dolicocefalia & 38,5 \\
\hline Abaulamento frontal & 51,8 \\
\hline Prognatismo & 26,9 \\
\hline Queixo proeminente & 70,4 \\
\hline Hipertelorismo & 52 \\
\hline Fissura palpebral antimongolóide & 17,8 \\
\hline Estrabismo & 17,8 \\
\hline Orelhas grandes & 32 \\
\hline Implantação frontal do cabelo alta & 25,9 \\
\hline Idade óssea avançada & 75 \\
\hline Articulação frouxa & 23,8 \\
\hline Genu valgus & 11,8 \\
\hline Mãos grandes ( $p>97)$ & 70,4 \\
\hline Pés grandes ( $p>97)$ & 58,3 \\
\hline Pé plano & 39,1 \\
\hline Sindactilia nas mãos & 17,4 \\
\hline Sindactilia nos pés & 8,7 \\
\hline Unhas quebradiças e finas & 9,1 \\
\hline Defict de coordenação motora & 76 \\
\hline Hipotonia neonatal & 36 \\
\hline Atraso da linguagem & 78,6 \\
\hline Dificuldade de aprendizagem & 80 \\
\hline Convulsões com febre & 9,7 \\
\hline Convulsões sem febre & 15,6 \\
\hline Anomalias cerebrais & 16 \\
\hline Dificuldade de alimentação ao nascer & 17,2 \\
\hline Sialorréia & 19,2 \\
\hline Icterícia & 38,5 \\
\hline Otite & 12,5 \\
\hline Mau humor & 14,3 \\
\hline Agressividade & 10,7 \\
\hline Hiperatividade & 53,6 \\
\hline Ansiedade & 53,6 \\
\hline Comportamento anti-social & 21,4 \\
\hline
\end{tabular}




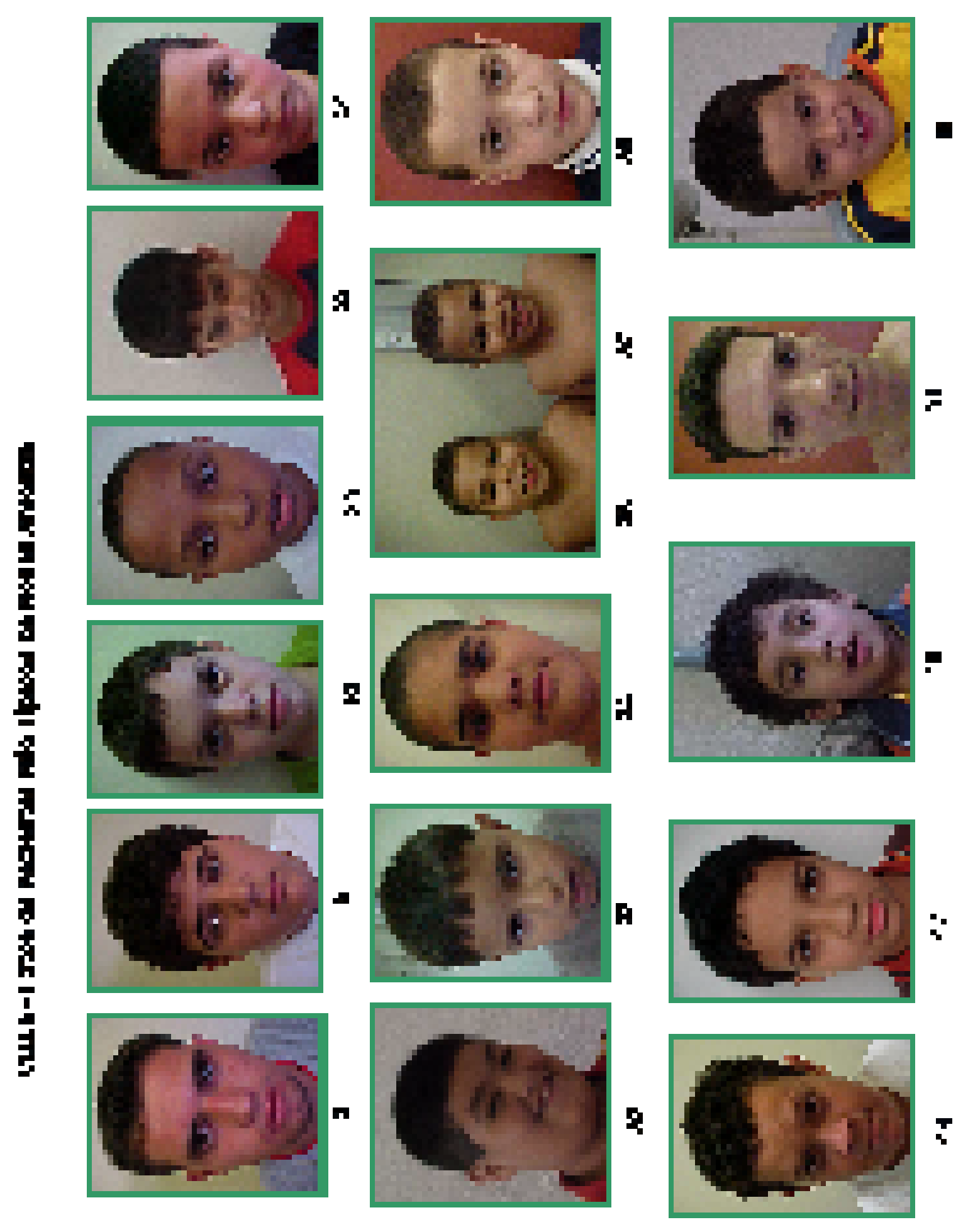




\section{IX- Referências Bibliográficas}

AASLAND, R.; GIBSON, T. J.; STEWART, A. F.: The PHD finger: implications for chromatin-mediated transcriptional regulation. Trends Biochemical Sciensce. 20(2):56-59, 1995.

AGWU, J. C.; SHAW, N. J.; KIRK, J.; CHAPMAN, D.; COLE, T. R. P.: Growth in Sotos Syndrome. Arch. Dis. Child. 80: 339-342, 1999.

AMBLER, G.: Overgrowth. Best Pratice \& Researche Clinical and Metabolism 16 (3): 519-546, 2002.

AMIEL, J.; FAIVRE, L.; WILSON, L.; LE MERRER, M.; MUNNICH, A.; WINTER, R,. LYONNET, S.; CORMIER-DAIRE, V.: Dysmorphism, variable bone age, and severe developmental delay: a "Sotos-like" Syndrome? J. Med. Genet. 39: 148-152, 2002.

BANNAYAN, G. A.: Lipomatosis, angiomatosis, and macrencephalia: a previously undescribed congenital syndrome. Arch. Path. 92: 1-5, 1971.

BATZER, M.A.; DEININGER, P. L.: Alu repeats and human genomic diversity. Nature reviews. 3: 370-380, 2002.

BECKWITH, J. B.: Extreme cytomegaly of the adrenal fetal cortex, omphalocele, hyperplasia of the kidney and pancreas, and Leydig-cell hyperplasia: another syndrome? Presented at the annual Meeting of the Western Society for Pediatric Research. Los Angeles, 1963. 
BEHMEL, A.; PLOCHL, E.; ROSENKRANZ, W.: A new X-linked dysplasia gigantism syndrome: identical with the Simpson dysplasia syndrome? Hum. Genet. 67: 409-413, 1984.

BOER, L.; VAN DUYVENVOORDE, H. A.; WILLEMSTEINS-VAN HOVE, E. C.; HOOGERBRUGGE, C. M.; VAN DOORN, J. MAASSEN, J. A.; KARPERIEN, M.; WIT, J. M.: Mutation in the NSD1 gene in patients with Sotos syndrome associate with endocrine e paracrine alterations in the IGF system. European Journal of Endocrinology. 151: 333-341, 2004.

BROWN, W. T.; WISNIEWSKI, K. E.; SUDHALTER, V.; KEOGH, M.; TSIOURIS, J.; MIEZEJESKI, C.; SCHAEFER, G. B.: Identical twins discordant for Sotos Syndrome. Am. J. Med Genet. 79: 329-333, 1998.

CHEN, C. P.; LIN, S. P.; LIN, C. C.; CHEN, Y. J.; CHERN, S. R.; LI, Y. C.; HSIEH, L. J.; LEE, C. C.; PAN, C. W.; WANG, W.: Molecular cytogenetic analysis of De Novo dup(5)(q35.2q35.3) and review of the literature of pure partial trisomy 5q. American Journal of medical Genetics Part A. 140: 1594-1600, 2006.

CITORES, L.; BAI, L.; SERENSEN, V.; OLSNES, S.: Fibroblast growth factor receptor-induced phosphorylation of STAT1 at the Golgi apparatus without translocation to the nucleus. J Cell Physiol. 212(1):148-56, 2007.

COHEN, M. M. JR.: A comprehensive and critical assessment of overgrowth and overgrowth syndromes. In: Advances in Human genetics, $\mathrm{H}$. Harris and $\mathrm{K}$. Hirschhorn, Eds., Plenum Press, New York, 1989, vol. 18, Chapter 4, pp. 181 303

COHEN, M. M. JR.: Perspectives on overgrowth syndromes. Am. J. Med. Genet. 79: 234-237, 1998. 
COHEN, M. M. JR.: Mental deficiency, alterations in performance, and CNS abnormalities in overgrowth syndromes. Am. J. Med. Genet. 117: 49-56, 2003.

COHEN, M. M. JR.: Proteus syndrome. Am. J. Med. Genet. 137: 38-52, 2005.

COLE, T. R. P.; HUGHES, H. E.: Sotos syndrome. J. Med. Genet. 27: 571-576, 1990.

COLE, T; HUGHES, H. : Sotos Syndrome: a study of the diagnostic criteria and natural history. J. Med. Genet. 31: 20-32, 1994.

COOPER, W. N.; CURLEY, R.; MACDONALD, F.; MAHER, E. R.: Mitotic recombination and uniparental disomy in Beckwith-Wiedemann syndrome. Genomics. 89: 613-617, 2007.

DEBAUN, M. R.; ESS, J.; SAUNDERS, S.:Simpson-Golabi-Behmel syndrome: progress toward understanding the molecular basis for overgrowth, malformation, and cancer predisposition. Molecular Genetics and Metabolism. 72: 279-286, 2001.

DOUGLAS, J.; HANKS, S.; TEMPLE, K. L.; DAVIES, S.; MURRAY, A.; UPADHYAYA, M.; TOMKINS, S.; HUGHES, H. E.; COLE, T. R. P.; RAHMAN, N. : NSD1 mutations are the major cause of Sotos Syndrome end occur in some cases of Weaver Syndrome but are rare in other overgrowth phenotypes. Am. J. Hum. Genet. 72: 000-000, 2003.

DOUGLAS, J.; COLEMAN, K.; TATTON-BROWN, T.; HUGHES, H.E.; TEMPLE, I.K.; COLE, T.R.P.; RAHMAN, N.: Evaluation of NSD2 and NSD3 in 
overgrowth syndromes. European Journal of Human Genetics. 13: 150153, 2005a.

DOUGLAS, J.; TATTON-BROWN, T.; COLEMAN, K.; GUERRERO, S.; BERG, J.; COLE, T.R.P.; FITZPATRICK, D.; GILLEROT, Y.; HUGHES, H.E.; PILZ, D.; RAYMOND, F.L.; TEMPLE, I.K.; IRRTHUM, A.; SCHOUTEN, J.P.; RAHMAN, N. : Parcial NSD1 deletions cause $5 \%$ of Sotos syndrome and are readily identifiable by multiplex ligation dependent probe amplification. J. Med. Genet. 56: 000-000, 2005b.

DVIR, M.; BEER, S.; ALADJEM, M.: Heredofamilial syndrome of mesodermal hamartomas, macrocephaly, and pseudopapilledema. Pediatrics 81: 287290, 1988.

ENKLAAR, T.; ZABEL, B. U.; PRAWITT, D.: Beckwith-Wiedemann syndrome: multiple molecular mechanisms. Expert reviews in molecular medicine. 8(17): 1-15, 2006.

ESCUDERO, I. R.; ROELANTS, F. M.; THORNER, J.; NOMBELA, C.; MOLINA, M.; CID, V. J.: Reconstitution of the mammalian PI3K/PTEN/Akt pathway in yeast. Biochemical Journal. 390: 613-623, 2005.

FARAVELLI, F.: NSD1 Mutations in Sotos Syndrome. American Journal of medical Genetics Part C. 137C: 24-31, 2005.

GOLABI, M.; ROSEN, L.: A new X-linked mental retardation-overgrowth syndrome. Am. J. Med. Genet. 17: 345-358, 1984.

GOLDSTEIN, D. J.; WARD, R. E.; MOORE, E.; FREMION, A. S.; WAPPNER, R. S. : Overgrowth, congenital hypotonia, nystagmus, strabismus, and mental 
retardation: variant of dominantly inherited Sotos sequence? Am. J. Med. Genet. 29: 783-792, 1988.

GORLIN, R. J.; COHEN, M. M.; LEVIN L. S. : Overgrowth syndromes and postnatal onset obesity syndromes.In: Syndromes of the Head and Neck. New York: Oxford Univ. Press (3rd ed.): 323-352, 1990.

HALAL, F.: Male to male transmission of cerebral gigantism. Am. J. Med. Genet. 12: 411-419, 1982.

HENDRIKS, Y. M. C.; VERHALLEN, J. T. C. M.; VAN DER SMAGT, J. J.; KANT, S. G.; HILHORST, Y.; HOEFSLOOT, L.; HANSSON, K. B. M.; VAN DER StRAATEN, P. J. C.; BOUTKAN, H.; BREUNING, M. H.; VASEN, H. F. A.; BRÖCKER-VRIENDS, A. H. J. T.: Bannayan-Riley-Ruvalcaba syndrome syndrome: further delineation of the phenotype and management of PTEN mutation-positive cases. Familial Cancer. 2: 79-85, 2003.

HIRSCH, E.; COSTA, C.; CIRAOLO, E.: Phosphoinositide 3-kinases as a common platform for multi-hormone signaling. Journal of Endocrinology. 194: 243256, 2007.

HÖGLUND, P.; NUROTAKI, N.; KYTÖLÄ, S.; MYAKE, N.; SOMER, M.; MATSUMOTO, N.: Familial Sotos Syndrome is caused by a novel 1 bp deletion of the NSD1 gene. J. Med. Genet. 40: 51-54, 2003.

HOOK, E. B.; REYNOLDS, J. W. : Cerebral gigantism: endocrinological and clinical observations of six patients including a congenital giant, concordant monozygotic twins, and a child who achieved adult gigantic size. J. Pediat. 70: 900-914, 1967. 
HUANG, N; BAUR, E; GARNIER, J; LEROUGE, T; VONESCH, J ; LUTZ, Y; CHAMBON, P; LOSSON, R.: Two distinct nuclear receptor interaction domains in NSD1, a novel SET protein that exhibits characteristics of both corepressor and coatvators. European Molecular Biology Organization Journal. 17 (12): 3398-3412, 1998.

IMAIZUMI, K.; KIMURA, J.; MATSUO, M.; KUROSAWA, K.; MASUNO, M.; NIIKAWA, N.; KUROKI, Y. : Sotos Syndrome associated with a de novo balanced reciprocal translocation t(5;8)(q35;q24.1). Am. J. Med. Genet. 107: 58-60, 2002.

JENUWEIN, T.; LAIBLE, G.; DORN, R.; REUTER, G.: SET domain proteins modulate chromatin domains in eu- and heterocromatin. Cellular and Molecular Life Sciences. 54: 80-93, 1998.

KAMIMURA, J.; ENDO, Y.; KUROTAKI, N.; KINOSHITA, A.; MIYAKE, N.; SHIMOKAWA, O.; HARADA, N.; VISSER, R.; OHASHI, H.; MIYAKAWA, K.; GERRITSEN, J.; INNES, A. M.; LAGACE, L.; FRYDMAN, M.; OKAMOTO, N.; PUTTINGER, R.; RASKIN, S.; RESIC, B.; CULIC, V.; YOSHIURA, K.; OHTA, T.; KISHINO, T.; ISHIKAWA, M.; NIIKAWA, N.; MATSUMOTO, N. : Identification of eight novel NSD1 mutation in Sotos Syndrome. J. Med. Genet. 40: 126, 2003.

KANEKO, H.; TSUKAHARA, M.; TACHIBANA, H.; KURASHIGE, H.; KUWANO, A.; KAJII, T. : Congenital heart defects in Sotos sequence. Am. J. Med. Genet. 26: 569-576, 1987.

KANEMOTO, N; KANEMOTO, K; NISHIMURA, G; KAMODA, T; VISSER, R; SHIMOKAWA, O; MATSUMOTO, N.: Nevo Syndrome With a NSD1 Deletions: a variant of Sotos síndrome. American Journal of medical Genetics. 140A: 70-73, 2006. 
KREPISCHI-SANTOS, A.C.V.; VIANNA-MORGANTE, A.M.; JEHEE, F.S.; PASSOS-BUENO, M.R.; KNIJNENBURG, J.; SZUHAI, K.; SLOOS W.; MAZZEU, J.F., KOK, F.; CHEROKI, C.; OTTO, P.A.; MIGRONI-NETTO, R.C.; VARELA, M.; KOIFFMANN, C.; KIM, C.A.; BERTOLA, D.R.; PEARSON, P.L.; ROSENBERG, C.: Whole-genome array-CGH screening in undiagnosed syndromic patients: old syndromes revisited and new alterations. Cytogenetic and Genome Research, 115: 254-261, 2006.

KUROTAKI, N.; HARADA, N.; YOSHIURA, K.; SUGANO, S.; NIIKAWA, N.; MATSUMOTO,N. : Molecular characterization of NSD1, a human homologue of the mouse Nsd1 gene. Gene. 279: 197-204, 2001.

KUROTAKI, N.; IMAIZUMI, K.; HARADA, N.; MASUNO, M.; KONDOH, T.; NAGAI, T.; OHASHI, H.; NARITOMI, K.; TSUKAHARA, M.; MAKITA, Y.; SUGIMOTO, T.; SONODA, T.; HASEGAWA, T.; CHINEN, Y.; TOMITA, H.; KINOSHITA, A.; MIZUGUCHI, T.; YOSHIURA, K.; OHTA, T.; KISHINO, T.; FUKUSHIMA, Y.; NIIKAWA, N.; MATSUMOTO,N.: Haploinsufficiency of NSD1 causes Sotos syndrome. Nature Genetics. 30: 365-366, 2002.

KUROTAKI, N.; STANKIEWICS, P.; WAKUI, K.; NIIKAWA, N.; LUPSKI, J.R.: Sotos syndrome common deletion is mediated by directly oriented subunits within inverted Sos-REP low-copy repeats. Human Molecular Genetics. 14(4): 535-542, 2005.

LAPUNZINA, P. Risk of tumorigenesis in overgrowth syndromes: a comprehensive review. Am J Med Genet C Semin Med Genet. 137(1):53-71, 2005.

LI, M.; SHUMAN, C.; FEI, Y.L.; CUTIONGCO, E.; BENDER, H. A.; STEVENS, C.; WILKINS-HAUG, L.; DAY-SALVTORE, D.; YONG, S. L.; GERAGHTY, M. T.; SQUIRE, J.; WEKSBERG, R.: GPC3 muation analysis in a spectrum of 
patients with overgrowth expands the phenotype of Simpson-Golabi-Behmel syndrome. American Journal of medical Genetics. 102: 161-168, 2001.

MARSH, D. J.; KUM, J. B.; LUNETTA, K. L.; BENNET, M. J.; GORLIN, R. J.; AHMED S. F.; BODURTHA, J.; CROWE, C.; CURTIS, M. A.; DASOUKI, M.; DUNN, T.; FEIT, H.; GERAGHTY, M. T.; GRAHAM JR, J. M.; HODGSON, S. V.; HUNTER, A.; KORF, B. R.; MANCHESTER, D.; MIESFELDT, S.; MURDAY, V. A.; NATHANSON, K. L.; PARISI, M.; POBER, B.; ROMANO, C.; TOLMIE, J. L.; TREMBATH, R.; WINTER, R. M.; ZACKAI, E. H.; ZORI, R. T.; WENG L. P.; DAHIA, P. L. M.; ENG, C.: PTEN mutation spectrum and genotype-phenotype correlations in Bannayan-Riley-Ruvalcaba syndrome suggest a single entity with Cowden syndrome. Human Molecular Genetics. 8(8): 1461-1472, 1999.

MELCHIOR, L.; SCHWATZ, M.; DUNO, M.: dHPLC screening of the NSD1 gene identifies nine novel mutations - summary of the first 100 Sotos Syndrome mutations. Annals of Human Genetics. 69: 222-226, 2005.

MIYAKE, N.; KUROTAKI, N.; SUGAWARA, H.; SHIMOKAWA, O.; HARADA, N.; KONDOH, T.; TSUKAHARA, M.; ISHIKIRIYAMA, S.; SONODA, T.; MIYOSHI,Y.; SAKAZUME, S.; FUKUSHIMA, Y.; OHASHI, H.; NAGAI, T.; KAWAME, H.; KUROSAWA, K.; TOUYAMA, M.; SHIIHARA, T.; OKAMOTO, N.; NISHIMOTO, J.; YOSHIURA, K.; OHTA, T.; KISHINO, T.; NIIKAWA, N.; MATSUMOTO, N. : Preferencial paternal origin of microdeletions caused by prezygotic chromosome or chromatid rearrangements in Sotos Syndrome. Am. J. Hum. Genet. 72: 1331-1337, 2003.

MIYAO, C. R.; ALVES, R. S. C.; GIGLIO, A. E.; KOIFFMANN, C. P.; OKAY, Y.: Síndrome de Sotos. Pediatria (São Paulo). 20(4): 412-415, 1998. 
MORETTI-FERREIRA, D.: Macrossomias na infância: estudo genético-clínico de 32 portadores de macrossomia associada a síndromes disfórmicas. São Paulo, 1995 (Dissertação de Doutorado, Departamento de Biologia, Instituto de Biociências da USP).

MURRELL, A.; HEESON, S.; COOPER, W. N.; DOUGLAS, E.; APOSTOLIDOU, S.; MOORE, G. E.; MAHER, E. R.; REIK, W.: An association between variants in the IGF2 gene and Beckwith-Wiedemann syndrome: interaction between genotype and epigenotype. Human Molecular Genetics. 13(3): 247-255, 2004.

NAGAI, T.; MATSUMOTO, N.; KUROTAKI, N.; HARADA, N,. NIIKAWA, N.; OGATA, T.; IMAIZUMI, K.; KUROSAWA, K.; KONDOH,T.; OHASHI, H.; TSUKAHARA, M.; MAKITA, Y.; SUGIMOTO, T.; SONADA, T.; YOKOYAMA, T.; UETAKE, K.; SAKAZUME, S.; FUKUSHIMA, Y.; NARITOMI, K. : Sotos Syndrome and haploinsufficiency of NSD1: clinical features of intragenic mutations and submicroscopic deletion. J. Méd. Genet. 40: 285-289, 2003.

NERI, G.; MARINI, R.; CAPPA, M.; BORRELLI, P.; OPITZ, J. M.: Simpson-GolabiBehmel syndrome: an X-linked encephalo-trophoschisis syndrome. Am. J. Med. Genet. 30: 287-299, 1988.

NEVO, S.; ZELTZER, M.; BENDERLY, A.; LEVY, J.: Evidence for autosomal recessive inheritance in cerebral gigantism. J. Med. Genet. 11: 158-165, 1974.

OPITZ, J. M.; WEAVER, D. W.; REYNOLDS J. F.; The syndromes of Sotos and Weaver: report and review. Am. J. Med. Genet. 79: 294-303, 1998.

PILIA, G.; HUGHES-BENZIE, R. M.; MACKENZIE, A.; BAYBAYAN, P.; CHEN, E.Y.; HUBER, R.; NERI, G.; CAO, A.; FORABOSCO, A.; SCHLESSINGER, 
D.: Mutations n GPC3, a glypican gene, cause the Simpson-Golabi-Behmel overgrowth syndrome. Nature genetics. 12: 241-247, 1996.

PEZZOLESI, M. G.; LI, Y.; ZHOU, X. P.; PILARSKI, R.; SHEN, L.; ENG, C.: Mutation-positive and mutation-negative patients with Cowden and Bannayan-Riley-Ruvalcaba syndromes associate with distinct $10 \mathrm{q}$ haplotypes. Am. J. Hum. Genet. 72: 923-934, 2006.

RAHMAN, N.: Mechanisms predisposing to childhood overgrowth and cancer. Current Opinion in Genetics \& Development. 15: 227-233, 2005.

RAYASAM, G, V; WENDLING, O; ANGRAND, P; MARK, M; NIEDERREITHER, K; SONG, L; LEROUGE, T; HAGER, G, L; CHAMBON, P; LOSSON, R.: NSD1 is essential for early post-implantation development ang has a catalytically active SET domain. European Molecular Biology Organization Journal. 22 (12): 3153-3163, 2003.

RILEY, H. D., JR.; SMITH, W. R.: Macrocephaly, pseudopapilledema and multiple hemangiomata: a previously undescribed heredofamilial syndrome. Pediatrics 26: 293-300, 1960.

RIO, M.; CLECH, L.; AMIEL, J.; FAIVRE, L.; LYONNET, S.; LE MERRER, M.; ODENT, S.; LACOMBE, D.; EDERY, P.; BRAUNER, R.; RAOUL, O.; GOSSET, P.; PRIEUR, M.; VEKEMANS, M.; MUNNICH, A.; COLLEAUX, L.; CORMIER-DAIRE, V. : Spectrum on NSD1 mutations in Sotos and Weaver Syndromes. J. Med. Genet. 40: 436-440, 2003.

RUVALCABA, R. H. A.; MYHRE, S.; SMITH, D. W.: Sotos syndrome with intestinal polyposis and pigmentary changes of the genitalia. Clin. Genet. 18: 413416, 1980. 
SAKAZUME, S.; OKAMOTO, N.; YAMAMOTO, T.; KUROSAWA, K.; NUMABE, H.; OHASHI, Y.; KAKO, Y.; NAGAI, T.; OHASHI H.: GPC3 mutation in seven patients with Simpson-Golabi-Behmel syndrome. Am. J. Med. Genet. Part A 143A: 1703-1707, 2007.

SAUGIER-VEBER, P. BONNET, C.; AFENJAR, A.; DROUIN-GERRAUD, V.; COUBES, C. ; FEHRENBACH, S. ; HOLDER-ESPINASSE, M.; ROUME, J.; MALAN, V.; PORTNOI, M.; JEANNE, N.; BAUMANN, C.; HÉRON, D.; DAVID, A.; GÉRARD, M.; BONNEAU, D.; LACOMBE, D.; CORMIERDAIRE, V.; VILLEMEUR, T. B.; FRÉBOURG, T.; BÜRGLEN, L.: Heterogeneity of NSD1 alterations in 166 patients with Sotos syndrome. Human Mutation. 0: 1-10, 2007.

SCHAEFER, G. B.; BODENSTEINER, J. B.; BUEHLER, B. A.: The neuroimaging findings in Sotos Syndrome. Am. J. Med. Genet. 68: 462-465, 1997.

SCHOUTEN, J.P.; McELGUNN, C.J.; WAAIJER, R.; ZWIJNENBURG, D.; DIEPVENS, F.; PALS, G. : Relative quantifications of 40 nucleic acid sequences by multiplex ligation-dependent probe amplification. Nucleic Acids Research. 30: 000-000, 2002.

SHAFFER, L. G.; LUPSKI, J. R.: Molecular Mechanisms for constitutional chromosomal rearrangements in human. Annu. Rev. Genet. 34: 297-329, 2000.

SHAW, L. C.; LUPSKI, J. R.: Implications of genome architecture for rearrangement-based disorders: the genomic basis of disease. Human Molecular Genetics. 13: 57-64, 2004. 
SIMPSON, J. L.; LANDEY, S.; NEW, M.; GERMAN, J.: A previously unrecognized X-linked syndrome of dysmorphia. Birth Defects Orig. Art. Ser. XI(2): 1824, 1975.

SMITH, M.; FULLWOOD, P.; QI, Y.; PALMER, S.; UPADHYAYA, M.; COLE, T. : No evidence for uniparental disomy as a common cause of Sotos syndrome. J. Med. Genet. 34: 10-12, 1997.

SOTOS, J. F.; DODGE, P. R.; MUIRHEAD, D.; CRAWFORD, J. F.; TALBOT, N. B.: Cerebral gigantism in childhood: a syndrome of excessively rapid growth with acromegalic features and nonprogressive neurologic disorder. N. Engl J. Med. 271: 109-116, 1964.

STANKIEWICZ, P.; LUPSKI, J.R.: Molecular evolutionary mechanisms for genomic disorders. Curr. Opin. Genet. Dev. 12(3): 312-319, 2002.

STEC, I.; NAGL, S. B.; OMMEN, G.J.B.; DUNNEN, J. T.: The PWWP domain: a potencial protein-protein interaction domain in nuclear proteins influencing differentiation? Federation of European Biochemical Societies: 473: 1-5, 2000.

TATTON-BROWN, K.; RAHMAN, N.; Clinical features of NSD1-positive Sotos syndrome. Clinical Dysmorphology. 13(4): 199-204, 2004.

TATTON-BROWN, K.; DOUGLAS, J; COLEMAN, K.; BAUJAT, G.; CHANDLER, K.; CLARKE, A.; COLLINS, A.; DAVIES, S.; FARAVELLI, F.; FIRTH, H.; GARRET, C.; HUGHES, H.; KERR, B.; LIEBELT, J.; REARDON, W.; SCHAEFER, G. B.; SPLITT, M.; TEMPLE, I. K.; WAGGONER, D.; WEAVER, D. D.; WILSON, L.; COLE, T.; CORMIER-DAIRE, V.; IRRTHUM, A.; RAHMAN, N.: Multiple mechanisms are implicated in the generation os $5 q 35$ microdeletion in Sotos syndrome. J. Med. Genet. 42: 307-313, 2005a. 
TATTON-BROWN, K.; DOUGLAS, J; COLEMAN, K.; BAUJAT, G.; COLE, T.; DAS, S.; HORN, D.; HUGHES, H. E.; TEMPLE, I. K.; FAVARELLI, F.; WAGGONER, D.; TÜRKMEN, S.; CORMIER-DAIRE, V.; IRRTHUM, A.; RAHMAN, N.: Genotype-phenotype associations in sotos syndrome: an analysis of 266 individuals with NSD1 aberrations. Am. J. Med. Genet. 77: 000-000, 2005b.

TATTON-BROWN, K.; RAHMAN, N.; Sotos syndrome. European Journal of Human Genetics. 13: 1-8, 2006.

THIFFAULT, I.; SCHWARTZ, C. E.; DER KALOUSTIAN, V.; FOULKES, W.D.:

Mutation analysis of the tumor suppressor PTEN and the glypican 3 (GPC3) gene in patients diagnosed with Proteus syndrome. Am J Med Genet Part A. 130(2): 123-127, 2004.

TÚRKMEN, S; GILLESSEN-KAEBACH, G; MEINECKE, P; ALBRECHT, B; NEUMANN, M, N; HESSE, V; PALANDUZ, S; BALG, S; MAJEWSKI, F; FUCHS, S; ZSCHIESCHANG, P; GREIWE, M; MENNICKE, K; KREUZ, F, R; DEHMEL, H, J; RODECK, B; KUNZE, J; TINSCHERT, S; MUNDLOS, S; HORN, D.: Mutations in NSD1 are responsible for Sotos syndrome, but are not a frequent finding in other overgrowth phenotypes. European Journal of Human Genetics. 11: 858-865, 2003.

VEUGELERS, M.; DE CAT, B.; MUYLDERMANS, S. Y.; REEKMANS, G.; DELANDE, N.; FRINTS, S.; LEGIUS, E.; FRYNS, J. P.; SCHRANDERSTUMPEL, C.; WEIDLE, B.; MAGDALENA, N.; DAVID, G.: Mutational analysis of the GPC3/GPC4 glypican gene cluster on Xq26 in patients with Simpson-Golabi-Behmel syndrome: identification of loss-of-function mutation in the GPC3 gene. Human Molecular Genetics. 9(9): 1321-1328, 2000. 
VISSER, R.; SHIMOKAWA, O.; HARADA, N.; NIIKAWA, N.; MATSUMOTO, N. : Non-hotspot-related breakpoints of common deletions in Sotos syndrome are located within destabilised DNA regions. J. Med. Genet. 42: 000-000, 2005.

WAGGONER, D. J.; RACA, G.; WELCH, K.; DEMPSEY, M.; ANDERES, E.; OStROVNAYA, I.; ALKHATEEB, A.; KAMIMURA, J.; MATSUMOTO, N.; SCHAEFFER, B.; MARTIN C. L.; DAS S.: NSD1 analysis for Sotos syndrome: insights and perspectives from the clinical laboratory. Genet Med. 7(8): 524-533, 2005.

WAITE, K. A.; ENG, C.: Protean PTEN: form and function. Am. J. Hum. Genet. 70: 829-844, 2002.

WEKSBERG, R.; SHUMAN, C.; SMITH, A. C.: Beckwith-Wiedemann syndrome. Am. J. Med. Genet. Part C. 137C: 12-23, 2005.

WEAVER, D. D.; GRAHAM, C. B.; THOMAS, I. T.; SMITH, D. W.: A new overgrowth syndrome with accelerated skeletal maturation, unusual facies, and camptodactyly. J. Pediat. 84: 547-552, 1974.

WIEDEMANN, H. R.: Tasks and problems of modern pediatrics. Med. West. 2: 8088, 1963.

WINSHIP, I. M.: Sotos syndrome--autosomal dominant inheritance substantiated. Clin. Genet. 28: 243-246, 1985.

ZONANA, J.; RIMOIN, D. L.; DAVIS, D. C.: Macrocephaly with multiple lipomas and hemangiomas. J. Pediat. 89: 600-603, 1976. 
ZONANA, J.; SOTOS, J. F.; ROMSHE, C. A.; FISHER, D. A.; ELDERS, M. J.; RIMOIN, D. L.: Dominant inheritance of cerebral gigantism. J. Pediat. 91: 251-256, 1977.

\section{Banco de dados eletrônicos:}

Ensembl Genome Browser:

http://www.ensembl.org

On Line Mendelian Inheritance in Man (OMIM, para MIM):

http://www.ncbi.nlm.nih.gov/sites/entrez 